\title{
Physical, Chemical, and Biological Aspects of Subsurface Organic Waste Injection near Wilmington, North Carolina
}

GEOLOGICAL SURVEY PROFESSIONAL PAPER 987

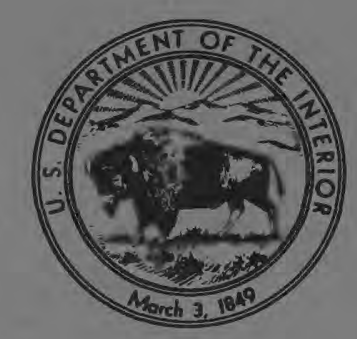


Physical, Chemical, and Biological Aspects of

\section{Subsurface Organic Waste Injection near Wilmington, North Carolina}

By J. A. LEENHEER, R. L. MALCOLM, and W. R. WHITE

GEOLOGICAL SURVEY PROFESSIONAL PAPER 987

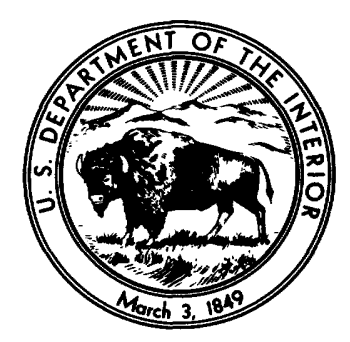




\section{UNITED STATES DEPARTMENT OF THE INTERIOR}

THOMAS S. KLEPPE, Secretary

GEOLOGICAL SURVEY

V. E. McKelvey, Director

Library of Congress Cataloging in Publication Data

Leenheer, J. A.

Physical, chemical, and biological aspects of subsurface organic waste injection near Wilmington, North Carolina.

(Geological Survey Professional Paper 987)

Supt. of Docs. no.: I 19.16:987

Bibliography: p.

1. Waste disposal in the ground-North Carolina-Wilmington region.

I. Malcolm, R. L., joint author. II. White, W. R., joint author. III. Title: Physical, chemical, and biological aspects of subsurface organic waste injection. . . IV. Series: United States Geological Survey Professional Paper 987.

TD761.L43 $628^{\prime} .36 \quad 76-608225$

For sale by the Superintendent of Documents, U.S. Government Printing Office Washington, D.C. 20402

Stock Number 024-001-02915-4 


\section{CONTENTS}

\begin{tabular}{|c|c|}
\hline Page & Page \\
\hline English-metric equivalents & Waste-aquifer interactions - Continued \\
\hline Abstract & Site study - Continued \\
\hline Introduction & Possible flow systems associated with injection \\
\hline Acknowledgments ..... & \\
\hline [ydrogeology, By H. M. Peek and R. C. Heath ....................... & $\begin{array}{l}\text { Microbiological study } \\
\text { Laboratory waste-aquifer reactivity studies }\end{array}$ \\
\hline Case history of waste injection & Introduction \\
\hline Installation and operation of initial well system ….............. 6 & Methods and materials \\
\hline & Aquifer material \\
\hline Field sampling methods & Characterization of aquifer material \\
\hline Industrial waste analysis. & Waste constituent analyses \\
\hline 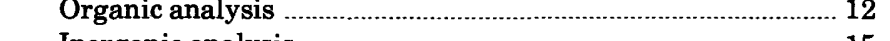 & 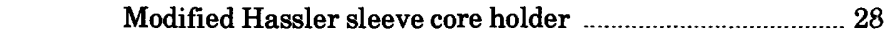 \\
\hline Inorganic analysis & 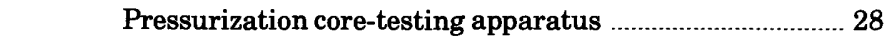 \\
\hline 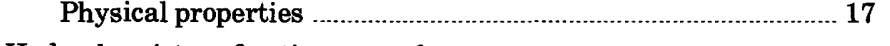 & Experimental design \\
\hline Hydrochemistry of native ground water.. & Testing the pressurization core-testing apparatus \\
\hline Waste-aquifer interactions .. & Leak testing \\
\hline Site study ......... & Packing the Teflon sleeve with aquifer material .. \\
\hline Initial conditions & Experiment 1-kinetic study of waste \\
\hline $\begin{array}{l}\text { Initial conceptual model of injected-waste reactivity } \\
\text { and movement }\end{array}$ & $\begin{array}{l}\text { Experiment } 2 \text {-core solubilization study } \\
\text { Experiment } 3 \text { - waste saturation study }\end{array}$ \\
\hline Reactions obser & nal conceptual model of waste movement and reactivity $\ldots . . . . . .39$ \\
\hline Reactions o & Immary and conclusions \\
\hline Reactions observed at wells 11,14 , and $15 \ldots$ & Selected references ................. \\
\hline
\end{tabular}

\section{ILLUSTRATIONS}

FIGURE 1. Hercules Inc. DMT Plant, Wilmington, North Carolina

2. Location of Hercules Inc., plant site.

3. Diagram showing hydrogeologic conditions and injection-well construction for well I-7A

4. Map of waste-injection and observation wells

5. Monthly average injection rate.

6. Graph of highest wellhead injection pressures

7. Location of wells in initial system and pressure surface, January 1969

8. Map of pressure surface, September 1970

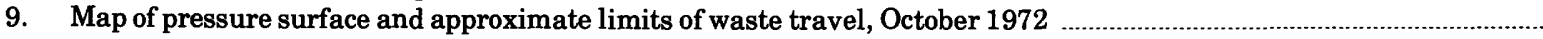

10. Map of pressure surface with no injection, April 1973

11. Construction features of observation well 14

12. Analytical scheme of organic waste analysis

13. Gas chromatogram of acetic and formic acids

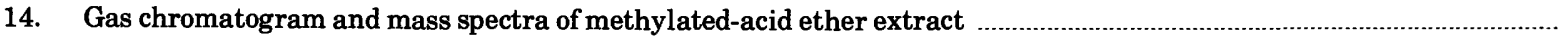

15. Gas chromatogram of alkaline ether extract

16. Gas chromatogram of neutral, volatile, waste constituents

17. Initial conceptual model of injected-waste reactivity and movement

18. Variations in $\mathrm{pH}$ and residue on evaporation from samples taken during observation of waste front in wells 1 and 5 ....

19. Variables observed during passage of waste front in well 14

20. Constituents measured during passage of waste front in well 11

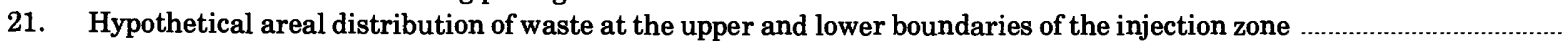

22. Probable internal circulation of ground water within well 14

23. Comparison of number of bacteria per millilitre (as colony-forming units) in waste front (well 14) and in uncontaminated aquifer (well 11)

24. Diagram of modified Hassler sleeve core holder

Page 
FIGURE 25. Schematic diagram of pressurization core-testing apparatus

26. Specific conductance breakthrough curve during leak-testing of Hassler sleeve core holder 29

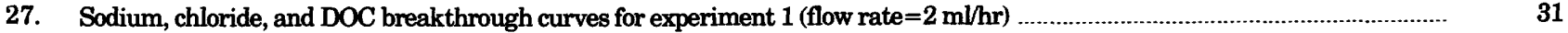

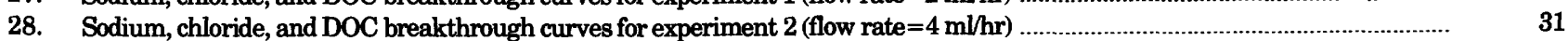

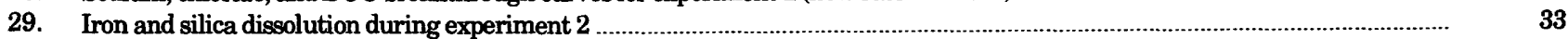

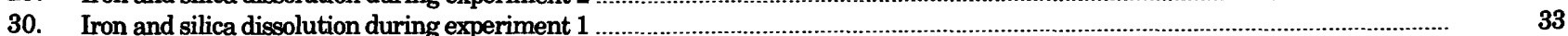

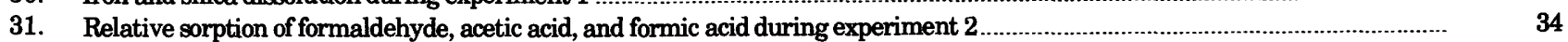

32. Relative sorption of phthalic, terephthalic, and p-toluic acids during experiment 1

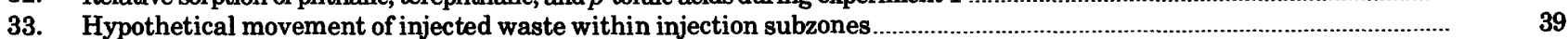

34. Final conceptual model of injected-waste reactivity and movement

\section{TABLES}

TABLE 1. Chronology of significant events during injection

2. Injection-system well data

3. Average organic analysis of waste

4. Inorganic waste analysis

Inorganic analysis of native ground water found in aquifers at waste-injection site

6. Change in water composition with waste contamination.

7. Well 14 gas analyses

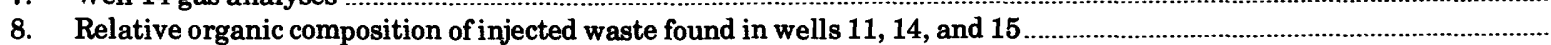

9. Observation well flow-test data

10. Identification of isolates from well 11

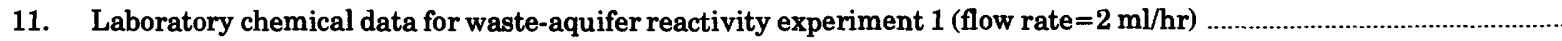

12. Laboratory chemical data for waste-aquifer reactivity experiment 2 (flow rate $=4 \mathrm{ml} / \mathrm{hr}$ )

13. Organic chemical data during waste-effluent monitoring of experiment 2 .

14. Organic chemical data during waste-effluent monitoring of experiment 1 .

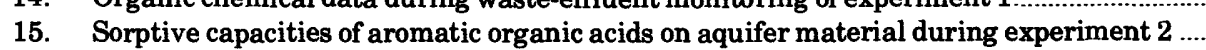

Organic and inorganic carbon analyses of fractionated and unfractionated injection-zone aquifer material ...................

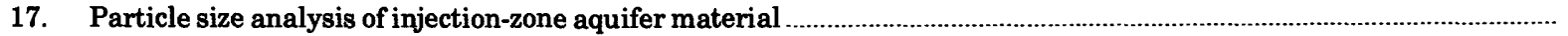

18. $\mathrm{Fe}, \mathrm{Al}$, and $\mathrm{Mn}$ analyses by graphite furnace technique of selected waste effluent fractions during experiment 2 ..........

19. Chemical data during waste effluent monitoring of experiment 3

20-36. Basic-data tables

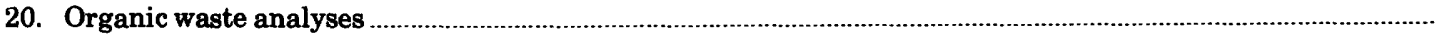

21. Waste inorganic analyses-sample collected 11-7-73

22. Inorganic analyses of water from surficial sand aquifer

23. Inorganic analyses of water from 300 -ft zone

24. Inorganic analyses of water from 500 - $\mathrm{ft}$ zone

25. Inorganic analyses of water from $700-\mathrm{ft}$ zone

26. Inorganic analyses of water from well 7 .

27. Inorganic analyses of water from well 11 .

28. Inorganic analyses of water from well 12

29. Inorganic analyses of water from well 14

30. Inorganic analyses of water from well 15

31. Inorganic analyses of water from well 16

32. Inorganic analyses of water from wells $2,3,4$, and 5 .

33. Gas analyses.

34. Organic analyses of water from well 11

35. Organic analyses of water from well 14

36. Organic analyses of water from well 15

\section{ENGLISH-METRIC EQUIVALENTS}

\begin{tabular}{lll}
\hline foot (ft) & $=0.3048$ & metre $(\mathrm{m})$ \\
inch (in) & $=25.4$ & millimetres $(\mathrm{mm})$ \\
mile (mi) & $=1.609$ & kilometres $(\mathrm{km})$ \\
pound per square inch (psi) & $=.068947$ & bar \\
gallon (gal) & $=3.785$ & litres $(\mathrm{l})$ \\
\hline
\end{tabular}




\title{
PHYSICAL, CHEMICAL, AND BIOLOGICAL ASPECTS OF SUBSURFACE ORGANIC WASTE INJECTION NEAR WILMINGTON, NORTH GAROLINA
}

\author{
By J. A. LeenheER, R. L. MAlcolm, and W. R. White
}

\begin{abstract}
From May 1968 to December 1972, an industrial organic waste was injected at rates of 100 to 200 gallons per minute (6.3 to 12.6 litres per second) into a sand, gravel, and limestone aquifer of Late Cretaceous age by Hercules Inc. located near Wilmington, North Carolina. This report presents both field and laboratory data pertaining to the physical, chemical, and biological effects of waste injection into the subsurface at this particular site, a case history of the operation, predictions of the reactions between certain organic wastes and the aquifer components, and descriptions of the effects of these reactions on the subsurface movement of the wastes.

The case history documents a situation in which subsurface waste injection could not be considered a successful means of waste disposal. The first injection well was used only for 1 year due to excessive wellhead pressure build-up above the specified pressure limit of 150 pounds per square inch (10.3 bars). A second injection well drilled as a replacement operated for only 5 months before it too began to have problems with plugging. Upward leakage of waste into shallower aquifers was also detected at several wells in the injection-observation well system. The multiple problems of plugging, high pressures, and waste leakage suggested that the reactive nature of the waste with the aquifer into which it was injected was the primary reason for the difficulties experienced with waste injection.
\end{abstract}

ABSTRACT
A site study was initiated in June 1971 to investigate wasteaquifer interactions. The first stage of the study determined the hydrogeologic conditions at the site, and characterized the industrial waste and the native ground water found in the injection zone and other aquifers. The injection zone consisted of multiple permeable zones ranging in depth from about 850 to 1,000 feet (259 to 305 metres) below land surface. In addition to the injection zone, aquifers were found near depths of $60,300,500$, and 700 feet $(18,91,152$, and 213 metres) below land surface. The aquifers from 300 feet (91 metres) down to the injection zone were flowing artesian with the natural pressure of the injection zone being 65 feet ( 20 metres) above land surface at the site.

The dissolved solids concentration in the native ground water increased with depth to an average value of $20,800 \mathrm{mg} / \mathrm{l}$ (milligram per litre) (two-thirds that of seawater) in the water from the injection zone. Sodium chloride was the major dissolved solid, and all of the ground water below 300 -feet (91-metres) depth was slightly alkaline.

Dissolved organic carbon of the industrial waste averaged 7,100 $\mathrm{mg} / \mathrm{l}$ and 95 percent of the organic carbon was identified and quantified. The major organic waste constituents in order of decreasing abundance were acetic acid, formic acid, $p$-toluic acid, formaldehyde, methanol, terephthalic acid, phthalic acid, and benzoic acid. Prior to injection, the waste was neutralized with lime to $\mathrm{pH} 4$ so that the major inorganic waste constituent was calcium at a concentration of $1,300 \mathrm{mg} / 1$.

The second stage of the site study involved the observation of waste-aquifer interactions at various wells as the waste arrived and passed by the wells. Water samples obtained from three observation wells located 1,500 to 2,000 feet (457 to 607 metres) from the original injection well gave evidence for biochemical waste transformations at low waste concentrations. Gas that effervesced from these water samples contained up to 54 percent methane by volume. Ferrous iron concentrations as high as $35 \mathrm{mg} / \mathrm{l}$, hydrogen sulfide gas, and sulfide precipitates were additional indicators of biochemical reductive processes in the subsurface environment. Approximately 3,000 organisms per millilitre were found in uncontaminated ground water from the injection zone whereas in waste-contaminated wells, the number increased to levels as high as $1,000,000$ organisms per millilitre. High concentrations of waste were found to be toxic to microorganisms. Most of the organisms isolated from uncontaminated wells were facultative, aerobic genera whereas the population changed to anaerobic strains in the contaminated wells. Methanogenic bacteria of the genus Methanobacterium and genus Methanococcus were isolated in pure culture from ground-water samples in which methane was found.

The relative ratios of formic acid, $p$-toluic acid, and terephthalic acid to acetic acid were lower in these ground-water samples than in the injected waste indicating degradation or sorption of formic, $p$-toluic, and terephthalic acids relative to acetic acid during the period of waste travel to these observation wells. The construction of the screened section of the observation wells allowed dilution of the waste and internal circulation of ground water so that it was impossible to determine quantitative waste concentrations in the various waste-receiving zones within the injection zone.

Highly contaminated ground-water samples obtained from five observation wells. located near (50 to 150 feet) (15 to 46 metres) the injection wells gave evidence for waste dissolution of aquifer carbonates and iron oxides. These samples contained carbon dioxide gas, calcium concentrations to $3,900 \mathrm{mg} /$, and iron concentrations to 310 $\mathrm{mg} /$. Organic complexation as well as acid dissolution was suspected to be the cause for the high iron concentrations. There was no microbiological activity apparent in these wells and samples.

Concurrent with and after the site study, a laboratory study was conducted in which waste was injected into cores of aquifer material obtained from the injection zione. The laboratory injection pressure was that of the hydrostatic pressure found in the injection zone. When a known volume of waste was injected into a core, the acidic 
waste initially dissolved the carbonates, and sesquioxide coatings on the primary minerals as evidenced by high concentrations of iron, aluminum, silica, and manganese. Iron concentrations as high as $200 \mathrm{mg} / \mathrm{l}$ were obtained, but this dissolved iron was eventually reprecipitated further on in the core when the $\mathrm{pH}$ of the waste rose to 5.5 to 6.0 because of neutralization of the waste by aquifer carbonates and oxides. Exhaustive leaching of a core by the acidic waste quantitatively dissolved the aquifer carbonates and removed approximately 12 percent of the extractable iron.

Sorption of the waste organic compounds upon the aquifer mineral constituents was found for all the waste organic acids. Formaldehyde was not sorbed. Sorption increased as the $\mathrm{pH}$ of the waste decreased with the exception of phthalic acid. Phthalic acid was complexed with dissolved iron, and its concentration decreased as the $\mathrm{pH}$ of the waste increased because it coprecipitated with the iron hydroxide precipitate. The waste solution was supersaturated with respect to terephthalic acid, and this constituent was found to be both highly adsorbed and precipitated in the core.

At the conclusion of this study, a conceptual model was constructed which by combining the results of the field and laboratory studies, detailed the various stages of injected waste reactivity and movement in the subsurface from the injection well to the edge of the waste front. The excessive pressure build-up in the injection wells was thought to be the result of a number of factors: reprecipitation of aquifer constituents initially dissolved by the acidic waste, precipitation of terephthalic acid, formation of carbon dioxide and methane gases, and the relatively low permeability and porosity of the injection zone. The leak problems were thought to arise from the dissolution of the cement grout around the casing by the waste acids of the injection wells and certain observation wells.

\section{INTRODUCTION}

Injection of liquid wastes into subsurface strata is a concept in waste management which has found widespread use in industry only since 1960 . A recent survey by Warner and Orcutt (1973) noted that only 22 waste injection wells were constructed before 1960 , and by 1964 , the number of injection wells had doubled. In spite of growing opposition to subsurface waste injection because of its largely unknown long-term environmental effects, the number of waste-injection wells has continued to increase until there are presently (1973) about 278 industrial waste-injection wells which have been constructed in 24 states. Wells used to reinject brines brought to the surface during oil and gas production were not included in this survey. In 1973, chemical, petrochemical, and pharmaceutical companies accounted for 57 percent of the industrial waste-injection wells.

This study is part of a nationwide effort by the U.S. Geological Survey to evaluate the environmental effects of subsurface waste injection. The specific objectives of this study were to: (1) Predict the reactions and interactions between certain organic wastes and aquifer components when organic wastes are placed in the subsurface environment and (2) define the effects that physical, chemical, and biological reactions have upon the distribution and movement of organic wastes in the subsurface.
In January 1971, the subsurface waste-injection system operated by Hercules Inc. near Wilmington, N.C., was selected for study. The site had several distinct advantages for this study: First, the industrial waste being injected into the subsurface contained high concentrations of several water-soluble organic compounds which were liable to react and be transformed in the subsurface environment. Prior to this study, problems with an injection well pressure build-up after a period of waste injection indicated that the reactivity of the injected waste with the injection zone was an important aspect concerning the operation of this waste-injection system. Secondly, a network of $14 \mathrm{ob}-$ servation wells located at various distances from the injection wells, and drilled to different depths, enabled the monitoring of waste movement and the collection of waste samples in both horizontal and vertical directions from the points of waste injection. Third, the relatively shallow depth to the waste-injection zone (1,000 feet or 300 metres) facilitated chemical and microbiological experimentation under the simulated pressures of the injection zone without the use of very high pressure equipment. Last but not least, excellent cooperation and support was provided by the Company and various state and federal agencies.

Disadvantages of this site were that the two injection wells and complex hydrogeologic nature of the injection zone made it very difficult to predict the rate and direction of waste movement. Therefore, no attempt was made to model the hydrological effects of waste injection. Second, because this study was initiated after the waste-injection system was planned, constructed, and brought into operation, there was no chance to influence the design, construction, placement, coring, and logging of the injection and observation wells which might have increased their utility as a research facility.

At the inception of this study, it was recognized that an interdisciplinary approach, which included organic chemistry, inorganic chemistry, microbiology, and hydrogeology, was necessary to understand and describe the several aspects of subsurface organic waste injection. Therefore, in this report, the organic and inorganic chemistry is the work of the authors; the microbiology and the hydrogeology are based on the work of others. (See section, "Acknowledgments".)

The Hercules Inc. plant is located on the Atlantic Coastal Plain approximately 4 miles northwest of Wilmington, N.C. A photograph of the plant is shown in figure 1 , and its location is shown on the map of figure 2. The product of the plant is dimethyl terephthalate (DMT), which is used in the production of synthetic polyester fibers. The organic byproducts of DMT manufacture were injected into the subsurface from May 1968 until December 1972. 


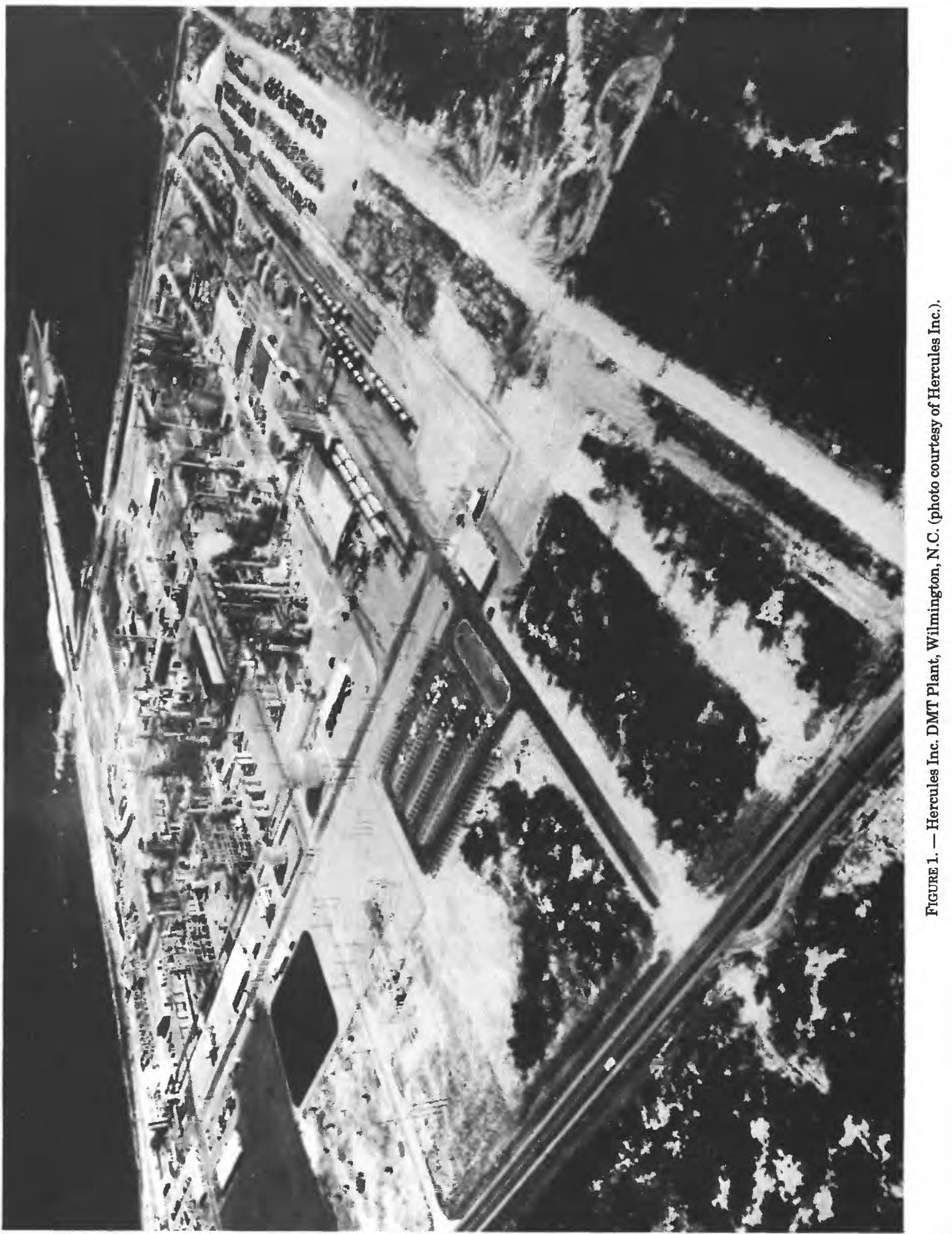



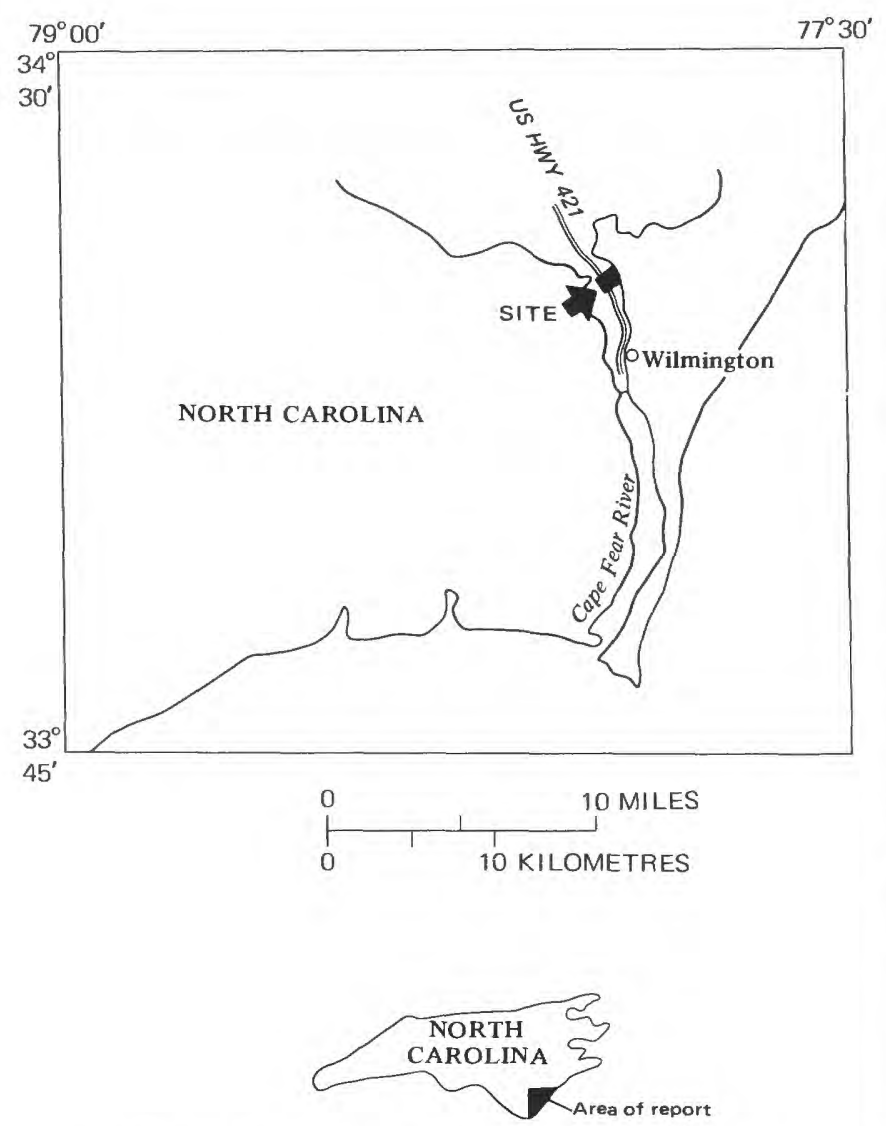

FIGURE 2. - Location of Hercules Inc., plant site.

When this study was initiated in January 1971 , the first injection well had been abandoned because of low input at maximum permitted pressure, and the drilling of the second injection well was under way. The first step of this study was to predict the chemical and microbial reactions which were probably occurring in the waste after injection. The predictions and some of the initial findings were given in a report to the Institute of Environmental Sciences (Leenheer and Malcolm, 1973a). A sampling and analytical program based on the hypothesized reactions was instituted, and additional findings were presented before the Second International Symposium on Underground Waste Management and Artificial Recharge (Leenheer and Malcolm, 1973b). Reports on the microbiological aspects (DiTommaso and Elkan, 1973) and a concurrent study on hydrogeological aspects (Peek and Heath, 1973) were also presented before this symposium.

Other reports which cover a period prior to and concurrent with this study are a status report by the North Carolina Department of Water and Air Resources (1971), and an engineering report on the injection well system by Black, Crow, and Eidsness, Inc. (1971). A discussion of the geology and ground-water hydrology of the Wilmington area is in a report by LeGrand (1960).

\section{ACKNOWLEDGMENTS}

The original interest and counsel of Raymond $\mathbf{L}$. Nace, and the late Charles L. McGuinness, were beneficial in establishing goals and providing direction during the initial stages of this study. Leonard A. Wood provided direction during the middle and latter stages of this study.

Dr. Gerald Elkan and Anthony DiTommaso conducted the microbiological studies at the Department of Microbiology, North Carolina State University, Raleigh. Their work was financed in part by the U.S. Geological Survey. Harry M. Peek, Chief, Ground Water Division, North Carolina Office of Water and Air Resources, and the North Carolina Board of Water and Air Resources were very helpful in facilitating the conduct of this study, and providing historical and background information. The drilling of the observation wells and the hydrogeological studies at the waste-injection site resulted from waste-monitoring requirements of the Office of Water and Air Resources. Ralph C. Heath, U.S. Geological Survey, Raleigh, N.C., gave valuable assistance in coordinating the efforts of the authors with the company, state, and federal agencies. He also assisted in the interpretation and writing of the hydrogeological study. Much of the material contained in the hydrogeology, case history, and microbiology sections of this report was previously published (Peek and Heath, 1973; DiTommaso and Elkan, 1973), and is reproduced in this report with the permission of the authors and the American Association of Petroleum Geologists.

Issac J. Winograd, U.S. Geological Survey, Reston, Va., assembled and organized data and records which predated the beginning of this study.

The cooperation and assistance of officials at Hercules Inc., Frank Parkinson, plant manager, J. Gale Wendle, Jr., and Al Lister, technical superintendents, and John Humphries, chemical engineer, are greatly appreciated. Charles Sever, consulting geologist with Black, Crow, and Eidsness, Inc., supplied the well logs and served as a consultant to Hercules Inc. on the well engineering and geohydrology at the injection site. Dr. Louis Adcock, Professor of Chemistry at the University of North Carolina at Wilmington, periodically collected samples at the injection site regardless of weather conditions and other obstacles.

Donald F. Goerlitz, U.S. Geological Survey, Menlo Park, Calif., lent invaluable aid and experience to the organic analysis phase of this study. Everett A. Jenne and Vance C. Kennedy, U.S. Geological Survey, Menlo Park, Calif., provided analytical assistance in trace- 
metal analysis. Donald W. Fisher, U.S. Geological Survey, Reston, Va., determined dissolved gases in the water samples.

\section{HYDROGEOLOGY}

\section{By H. M. PEEK and R. C. HEATH}

The Wilmington Area is underlain by coastal-plain sedimentary units more than $1,000 \mathrm{ft}(305 \mathrm{~m})$ thick. The sediments are predominantly of Late Cretaceous age and include ascending the Cape Fear, Middendorf, Black Creek, and Peedee Formations. The Castle Hayne Limestone of Eocene age overlies the Peedee in much of the area, but does not extend as far west as the Hercules site. Undifferentiated sands (probably of Pleistocene age), about 75 to $100 \mathrm{ft}(23$ to $30 \mathrm{~m}$ ) thick, overlie the Cretaceous strata at the Hercules site. As shown in figure 3, these units generally consist of interbedded sand, silty sand, clay, and some thin beds of limestone. The sediments are fine grained, with clay the predominant lithic unit. The beds of sand are thin and generally fine grained.

The surficial sand is the only freshwater aquifer beneath the site. The sand is very permeable and is a productive source of water. The rate of recharge is high as most of the precipitation enters the sand. Individual wells yield about $300 \mathrm{gal} / \mathrm{min}(1,136 \mathrm{l} / \mathrm{min})$, and the total withdrawal at the site is more than 6 million gal/day (23 million 1/day).

There are several relatively permeable artesian aquifers in the Cretaceous sediments, but none are very productive and all of them contain brackish water. The principal aquifers occur at depths of 300 to 350 $\mathrm{ft}$ ( 91 to $107 \mathrm{~m}), 475$ to $500 \mathrm{ft}$ (145 to $152 \mathrm{~m}), 660$ to 700 $\mathrm{ft}(201$ to $213 \mathrm{~m}), 850$ to $1025 \mathrm{ft}(259$ to $312 \mathrm{~m})$, as indicated in figure 3 .

The "300-ft" zone was sampled and the head was measured at several well sites during construction. Well 13 is the only well completed in this zone. The water from this well had a chloride concentration of $2,600 \mathrm{mg} / \mathrm{l}$. The head is about $29 \mathrm{ft}(8.8 \mathrm{~m})$ above sea level.

No wells have been constructed in the " 500 -ft" zone; however, samples for water analysis were collected during construction of wells 14 and 15 , and the chloride concentration of water from this zone was near $7,000 \mathrm{mg} / \mathrm{l}$. The artesian head was not measured.

Three wells have been constructed in the "700-ft" zone and, in addition, water-quality and water-level data were obtained during the construction of deeper wells. The chloride concentration of the water in this zone is about $10,000 \mathrm{mg} / \mathrm{l}$ and the natural head in this zone was about $38 \mathrm{ft}(12 \mathrm{~m})$ above sea level.

The zone between depths of 850 and $1,025 \mathrm{ft}$ ( 259 to $312 \mathrm{~m}$ ) is the injection zone. The water from this zone

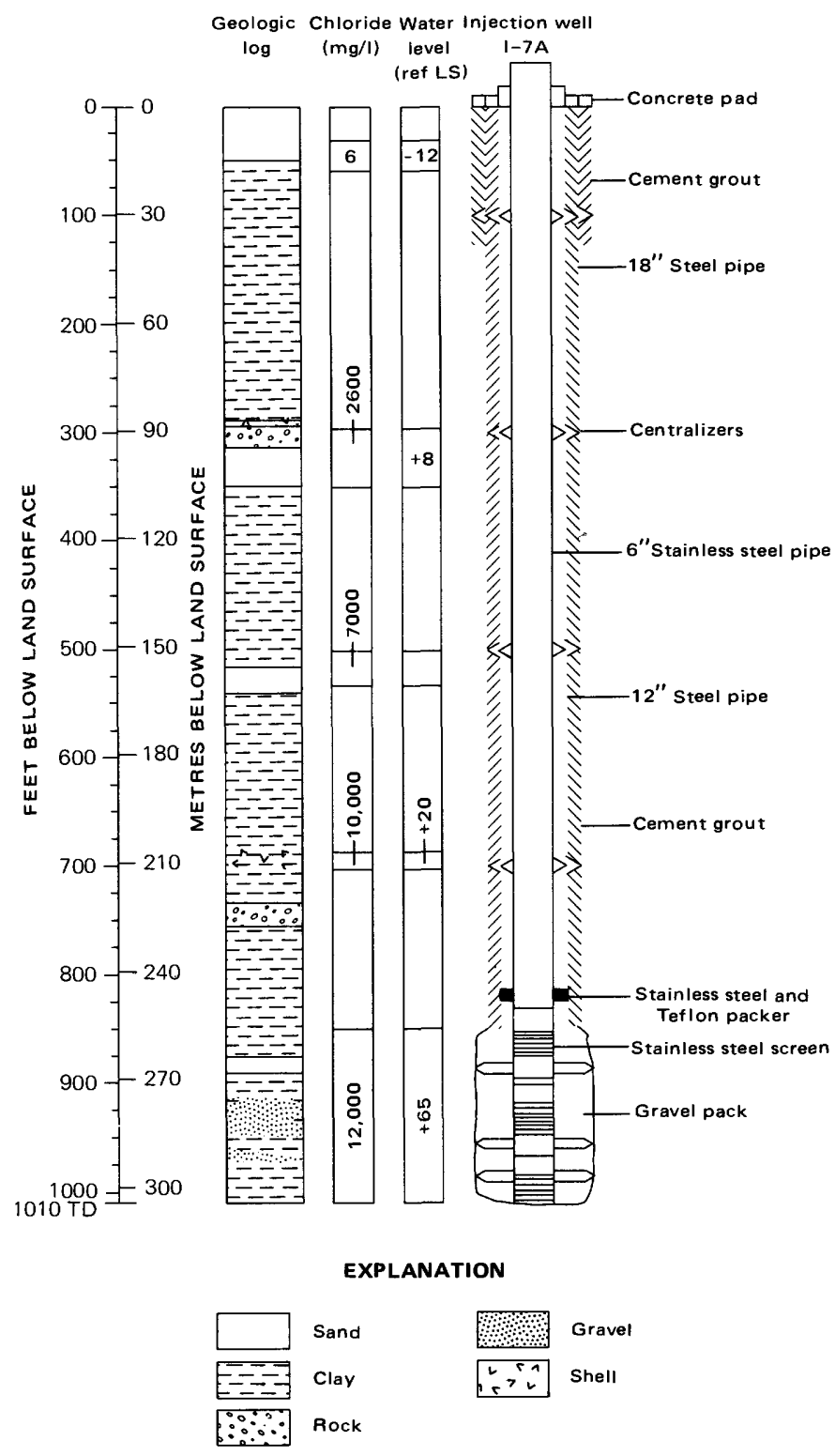

FIGURE 3.-Diagram showing hydrogeologic conditions and injection-well construction for well I-7A.

has a chloride concentration of nearly $12,000 \mathrm{mg} / \mathrm{l}$. The artesian head in this zone is unusually high, about 65 $\mathrm{ft}(20 \mathrm{~m})$ above land surface at the site, or about $90 \mathrm{ft}$ $(27 \mathrm{~m})$ above sea level. This zone was selected for waste injection for reasons of its greatest depth below the fresh ground-water zone, the high salinity of the ground water in this zone, and permeability which would permit waste injection at the rate of $200 \mathrm{gal} / \mathrm{min}$ (757 1/min).

The artesian conditions appear to be regional as indicated by the presence of freshwater to only very shallow depths over a large area along the Cape Fear arch, as first observed by LeGrand (1955), and more directly by recent exploration. The injection zone and the thick overlying confining bed are identifiable in a well near 
Calabash, about $45 \mathrm{mi}(72 \mathrm{~km})$ southwest of the Hercules site, which is approximately along the line of strike. The elevation of the artesian head is about 100 $\mathrm{ft}(30 \mathrm{~m})$ above sea level at Calabash. The water from this well has a chloride concentration of about 4,000 $\mathrm{mg} / \mathrm{l}$. The artesian head of a well completed at a depth of about $650 \mathrm{ft}(198 \mathrm{~m})$ at the Calabash site has an elevation of about $35 \mathrm{ft}(11 \mathrm{~m})$ above sea level, and the water has a chloride concentration of about $650 \mathrm{mg} / \mathrm{l}$.

The aquifer serving as the injection zone at the Hercules site consists of multiple layers of sand, silty sand, clay, and some thin beds of limestone. The overall permeability of this section, which is about 150 to 175 $\mathrm{ft}(45$ to $43 \mathrm{~m})$ thick, is very low although the permeability of the salty zones is relatively high. A temperature survey indicated that much of the waste entered a thin subzone at a depth of about $1,000 \mathrm{ft}(305 \mathrm{~m})$ in the initial injection well (I-6).

No long-term pumping test was made on the injection well prior to placing the system in operation. The injection rates fluctuated so greatly during the initial injection period that the data cannot be used to evaluate the hydraulic characteristics of the sub-zones. Tests on wells drilled later could not be made properly as the system was in operation and injection rates were not stable.

The high artesian pressure, particularly in the deeper aquifers, the generally low permeabilities of the aquifers, the thick zones of clay and silty sands, and the shallow depth to brackish water suggest slow natural circulation of water in the Cretaceous beds.

\section{CASE HISTORY OF WASTE INJECTION}

A chronology of the significant events which occurred during the four and one-half years of waste injection is given in table 1. A map showing locations of injection and observation wells is given in figure 4 .

\section{INSTALLATION AND OPERATION OF INITIAL WELLSYSTEM}

The initial well system consisted of one injection well (I-6) and four observation wells (numbers 1, 2, 4, and 5) completed at a depth of about $855-1025 \mathrm{ft}$ $(260-312 \mathrm{~m})$. Well 3 was completed in the first aquifer above the injection zone at about $660-690 \mathrm{ft}$ (201$213 \mathrm{~m}$ ) depth. The wells were cased with a special 10 -in. (250-mm) diameter fiberglass casing and equipped with stainless steel screens of 6 -in. (150-mm) diameter. The screens were set at the depths shown in table 2. The deep observation wells were equipped with plastic sampling tubes extending from the wellhead to the injection zone. Each well was equipped with a pressure gage on the wellhead and a manometer located at a central station. As shown in figure 4, the observation wells were only located at a maximum distance of $\mathbf{1 5 0}$ $\mathrm{ft}(45 \mathrm{~m})$ from the injection well, which was too close to indicate the magnitude and pattern of pressure change or to permit a reliable measurement of the travel time of the waste.

The injection of waste into the system was begun in TABLE 1.-Chronology of significant events during waste injection

\begin{tabular}{lc}
\hline Date & Event \\
\hline May 1968 & $\begin{array}{r}\text { Injection well I-6, and observation wells 1, 2, 4, } \\
\text { and 5 completed to 1,025-ft depth. Observation } \\
\text { well 3 completed to 700-ft depth. }\end{array}$
\end{tabular}

May 1968

Waste injection begun through injection well I-6.

September 1968 Waste was detected in wells 1, 2, 4, and 5.

June 1969

Waste injection shifted from well I-6 to wells 4 and 5 because of excessive injection pressures in well I-6.

November 1969 Injection well I-6 damaged during an attempt to reclaim the well. Waste injection continued through well 5 .

December 1970 Observation well 8 completed to 700-ft depth.

January 1971 Observation well 9 completed to 700-ft depth.

February 1971 Leakage of waste into the $700-\mathrm{ft}$ zone was detected at well 3.

April 1971

Injection well I-7A was completed to $1,050-\mathrm{ft}$ depth.

May 1971

Waste injection shifted from wells 4 and 5 to well I-7A.

May 1971

Observation wells 7 and 11 completed to $1,050-\mathrm{ft}$ depth.

May 1971

Wells 1 and I-6 were cemented to stop wasteleakage into the 700 -ft zone.

June 1971 Observation well 12 completed to 1,050-ft depth.

October 1971 Waste injection renewed through well 4 because well I-7A was not accepting all the waste at the specified injection pressure limit.

November 1971 Observation well 13 completed to $300-\mathrm{ft}$ depth.

December 1971 Waste detected in well 9 indicated waste leakage into the 700 -ft zone in that area.

December 1971 Pressure decrease in well 5 indicated possibility of waste leakage into an aquifer above the injection zone.

March 1972 Pressure decrease in well 2 indicated possibility of upward leakage of waste.

May 1972

Observation wells 14,15 , and 16 were completed to 1,050-ft depth.

June 1972

Waste was detected in well 14, and a weekly sampling program was instituted to monitor the passage of the waste front.

October 1972 Wells 2 and 5 were cemented to stop waste-leakage into the 700 -ft zone.

November 1972 Waste injection was gradually phased over to surface treatment of the waste.

December 1972 Waste injection terminated.

January 1973 Waste disappeared from well 14 after injection termination. 
TABLE 2.-Injection-system well data

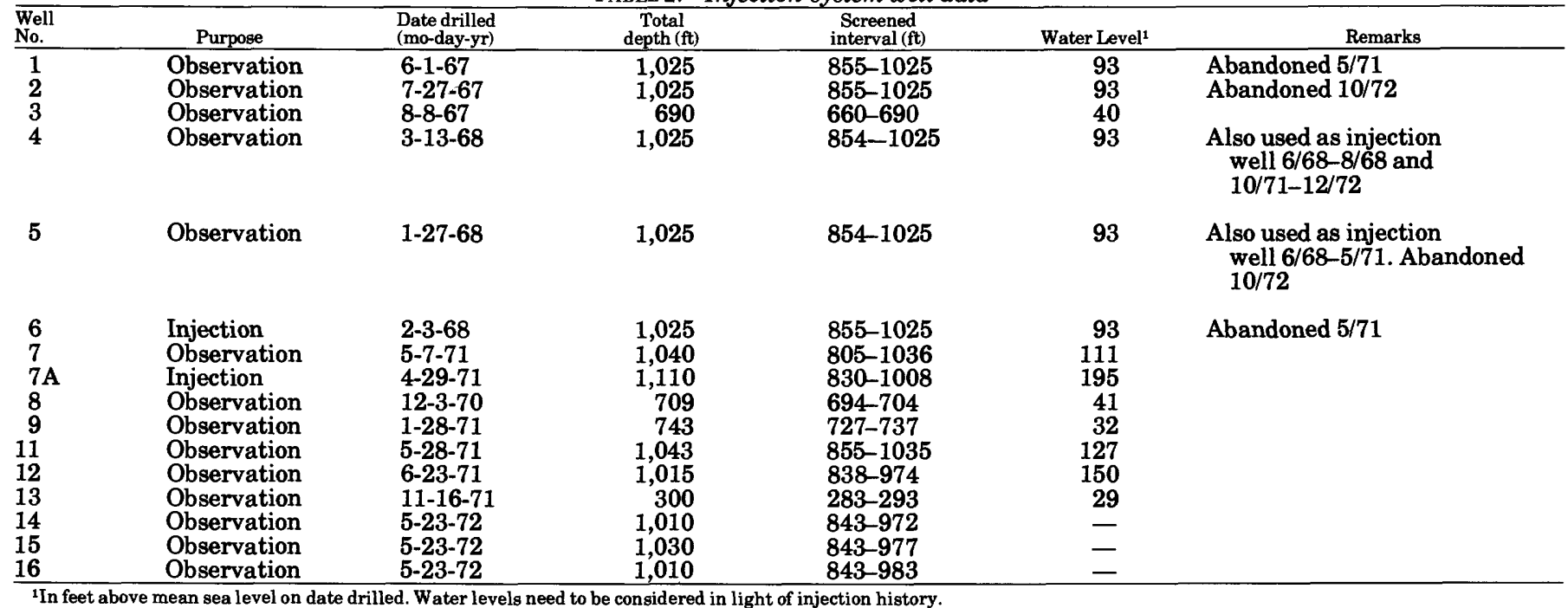

the latter part of May 1968 by intermittently injecting batch quantities at a rate of about $200 \mathrm{gal} / \mathrm{min}$ $(757 \mathrm{l} / \mathrm{min})$. As the volume of waste increased and the
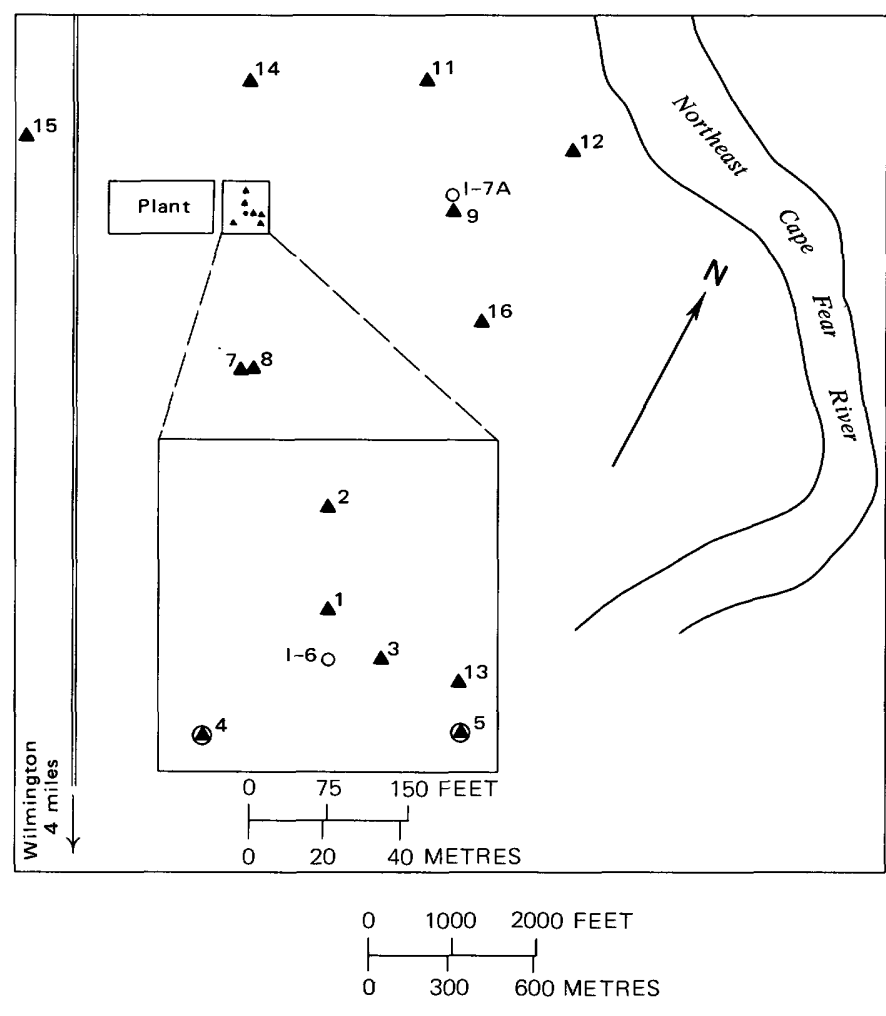

EXPLANATION

Injection well

- Observation well

(1) Observation well used

as injection well

Plant location - Lat $34^{\circ} 19^{\prime} \mathrm{N}$.;

Long $77^{\circ} 58^{\prime} \mathrm{W}$.

FIGURE 4.-Map of waste-injection and observation wells. periods of injection lengthened, the pressure rose sharply in the injection well and in the aquifer. The average monthly injection rate and the highest wellhead injection pressures, measured monthly or more frequently, are plotted on the graphs in figures 5 and 6 and reflect the early history of the system.

By September 1968, the waste was detected in samples collected from all existing observation wells (wells 1, 2, 4, and 5) in the injection zone. Only pH and dissolved solids were determined on samples collected during the passage of the waste front through the observation wells. There were no determinations of any gas constituents evolved from subsurface waste reactions, and no measurement of organic waste content. By May 1969, pressure in the injection well had reached the equivalent of $400 \mathrm{ft}(91 \mathrm{~m})$ above sea level, and about $165 \mathrm{ft}(50 \mathrm{~m})$ in the observation wells.

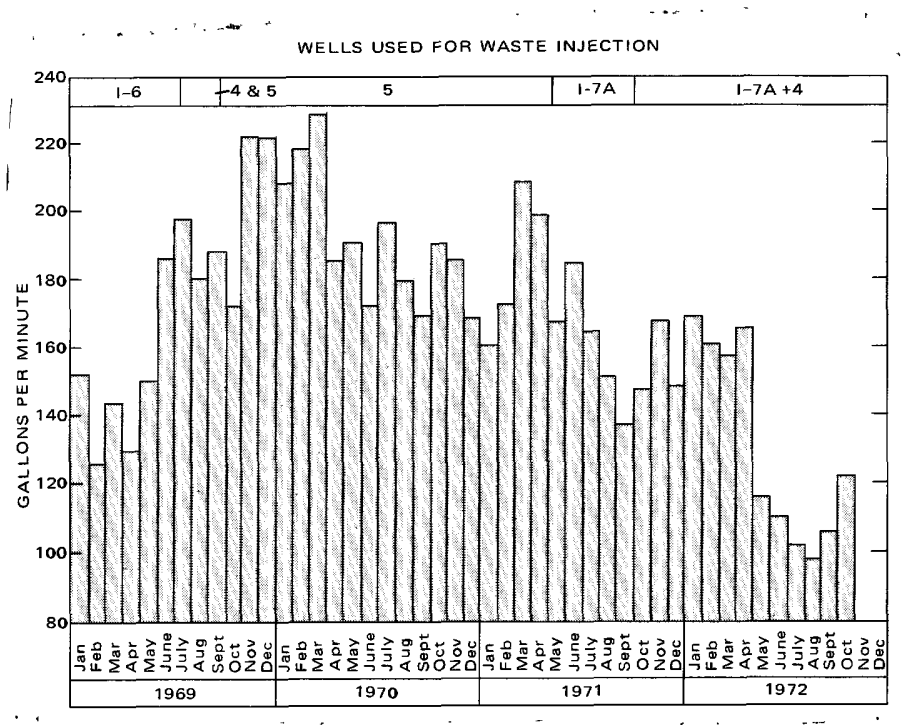

FIGURE 5.-Monthly average injection rate. Injection ceased December 1972. 


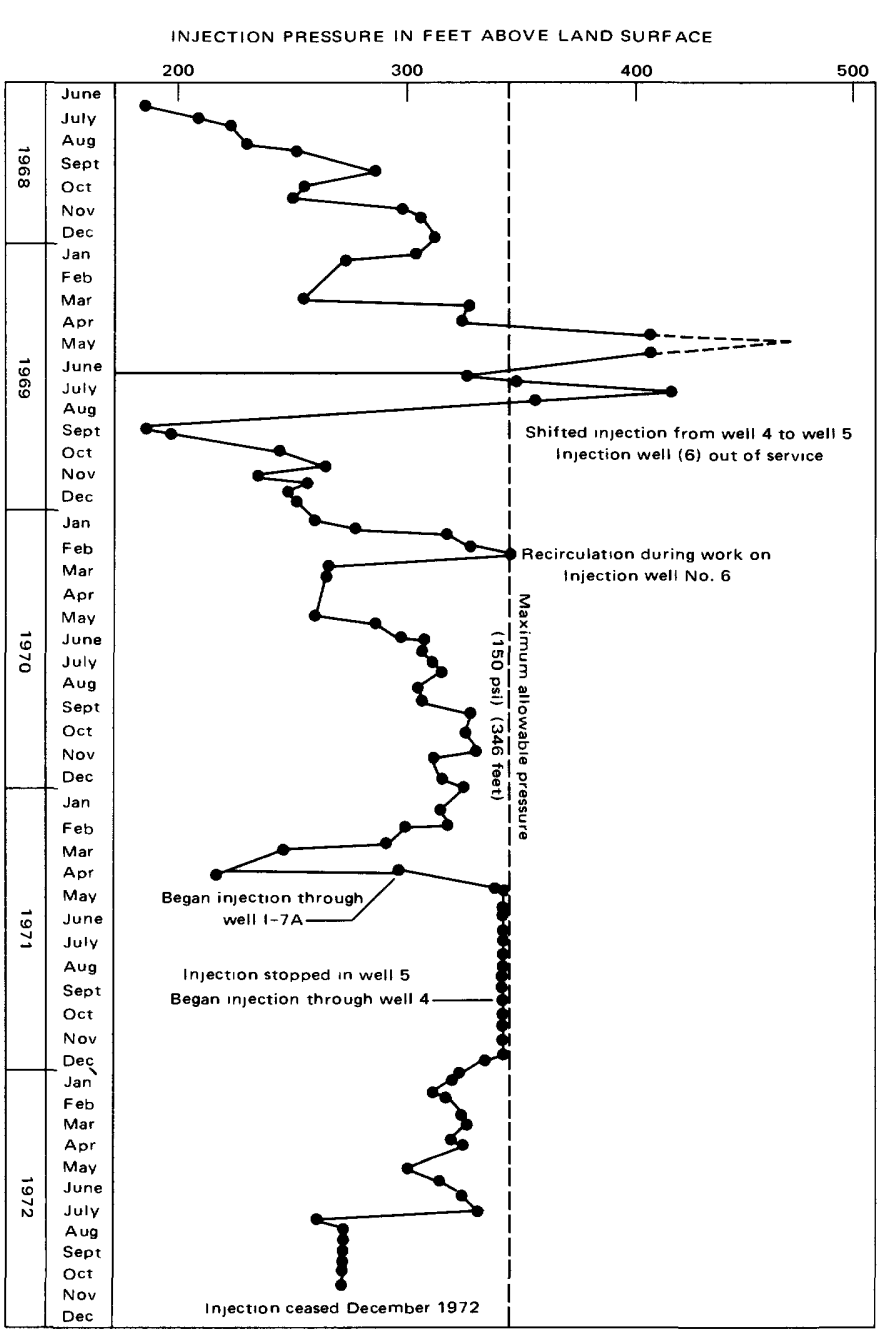

FIGURE 6.-Graph of highest wellhead injection pressures.

Figure 7 shows the oval pattern of the pressure surface in the injection zone in January 1969 which suggested the greatest waste movement to the northwest from well I-6. The injection pressure continued to rise to a high of more than $450 \mathrm{ft}(137 \mathrm{~m})$ by June 1969.

Because of the pressure build-up in the injection well, it was not possible to continue injection of waste at the rate of $300,000 \mathrm{gal} /$ day $(1,136,000 \mathrm{l} /$ day $)$, without exceeding the allowable limits of 150 psi (10.3 bars) specified by the injection permit. As the observation wells were of limited benefit after the waste had passed, the North Carolina Board of Water and Air Resources granted permission to the company for injection of the waste through wells 4 and 5 as an emergency measure to allow the plant to continue operating.

In November 1969, an attempt was made to reclaim the injection well by replacing the screened section, but this reclamation attempt was not successful and apparentiy damaged the casing because of subsequent

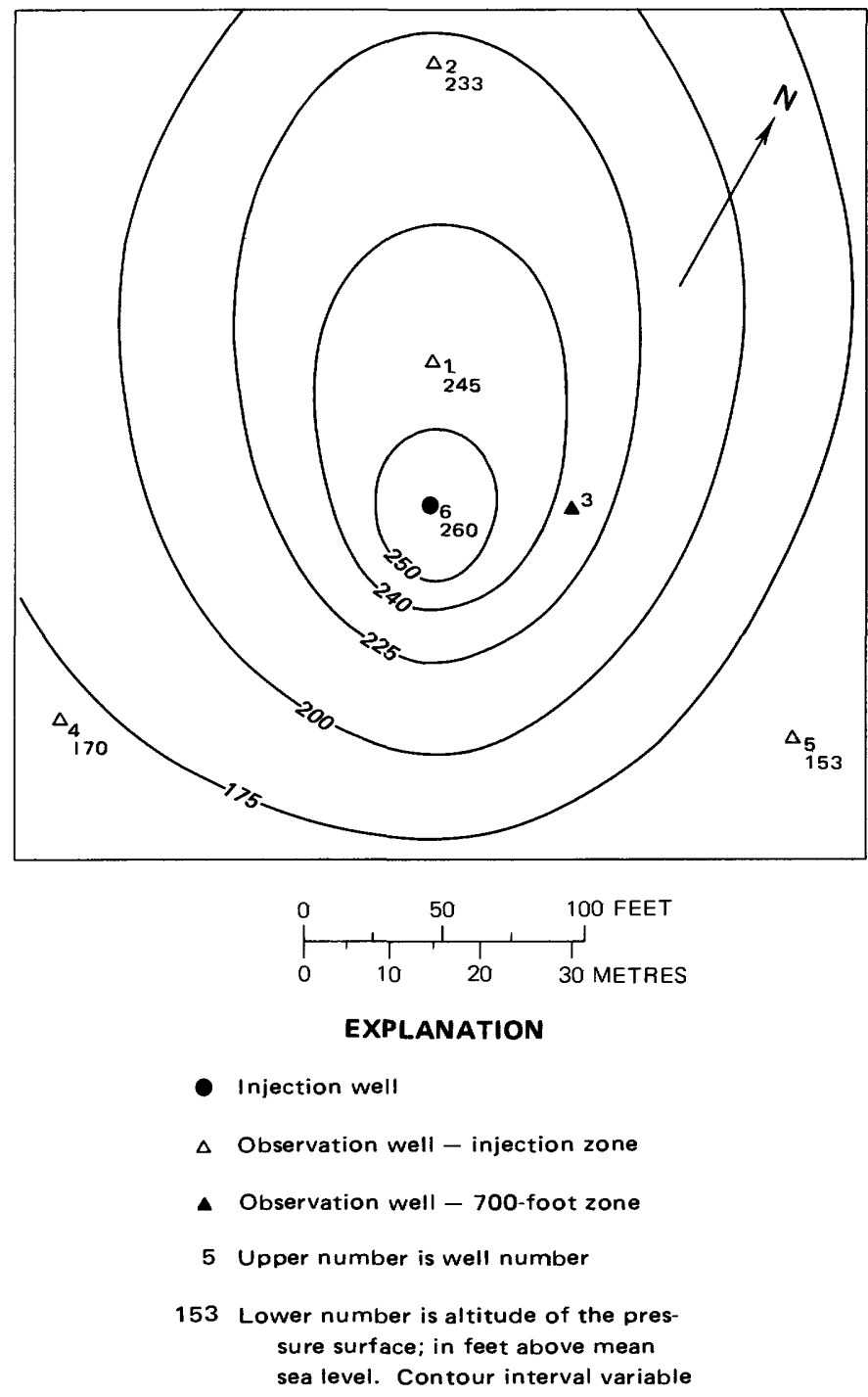

FIGURE 7.-Location of wells in initial system and pressure surface, January 1969.

waste leakage at this well. The pressure surface in late September 1970 , is shown in figure 8 . Well 6, the injection well, was out of service and well 5 was serving as the injection well. As may be noted, the low pressure at well I-6 indicates leakage from the injection zone through this well. In February 1971, a sudden pressure increase was noted in well 3 which is screened in the aquifer at a depth of 660-690 $\mathrm{ft}(201-$ $210 \mathrm{~m}$ ) and one month later in March, waste was detected in this well.

A caliper log taken in May 1971 just prior to the cementing, the injection well 6 showed a break in the casing of the well near $500 \mathrm{ft}(152 \mathrm{~m})$ depth. Apparently leakage of the waste had occurred for a long period of time into the aquifer at a depth of $500 \mathrm{ft}$ $(152 \mathrm{~m})$. This leakage had not been detected previously because of the absence of wells in the zone. A sonic log taken at this time indicated poor bonding between the 
cement casing and the formation between the injection zone and the 700-ft zone; therefore, the leak into the 700 -ft zone most likely originated from the injection zone with the waste rising into the $700-\mathrm{ft}$ zone around the outside of the well casing (C. Sever, oral commun., 1973). Well 1 in addition to injection well 6 was sealed with cement in May, 1971 because low pressure in well 1 indicated possible waste leakage also at this point. After cementing, the leakage apparently stopped because the pressure in the $700-\mathrm{ft}$ zone returned to normal within a few weeks, with most of the decline occurring within hours.

A request by the company to double the waste injection rate from $300,000 \mathrm{gal} /$ day to $600,000 \mathrm{gal} /$ day was denied by the North Carolina Office of Water and Air Resources in March, 1970. After a review of the opera-
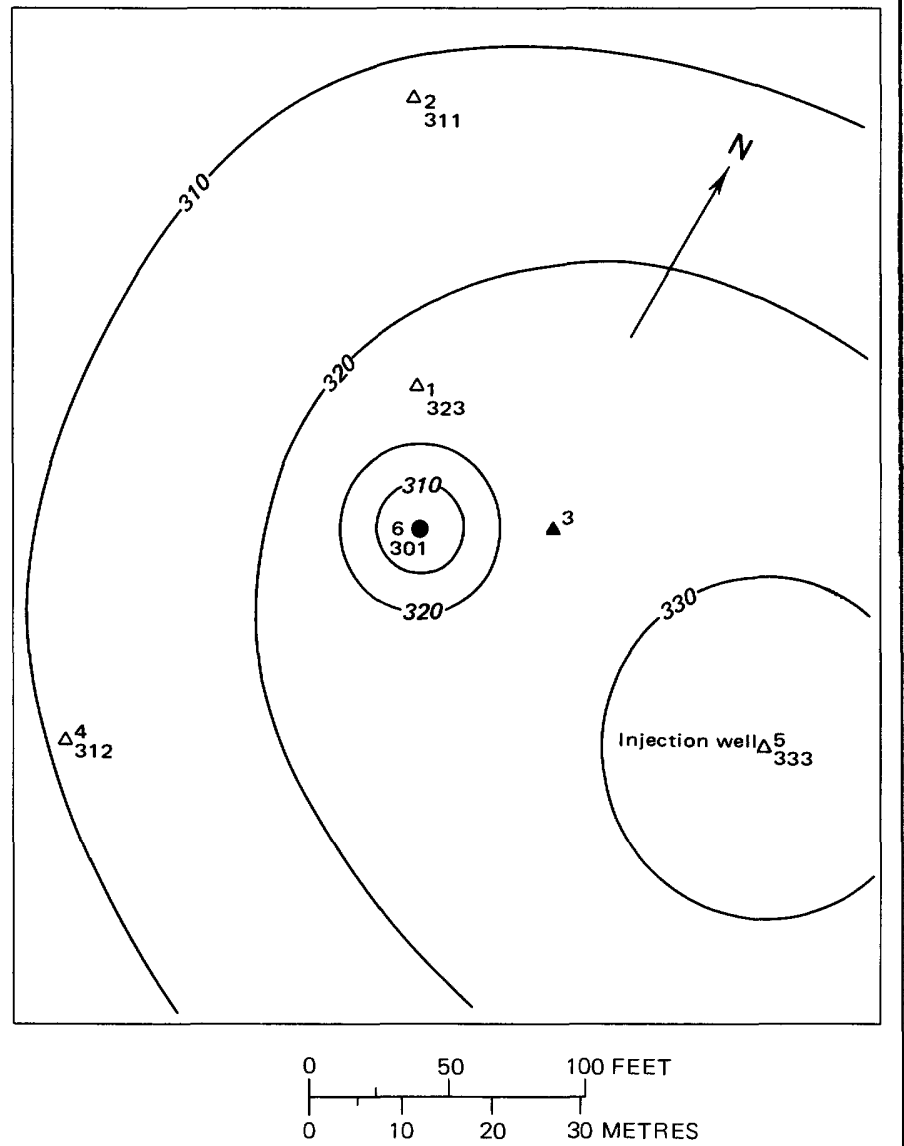

EXPLANATION

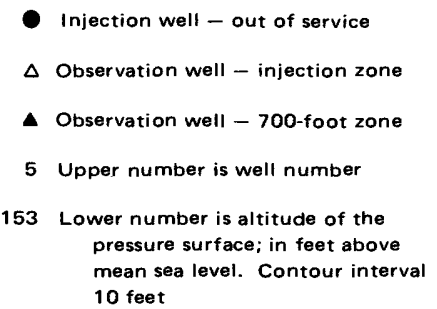

FTGURE 8.-Map of pressure surface, September 1970. tion of the system, in July 1970 the North Carolina Office of Air and Water Resources concluded that the operation of the system had not been successful, and that continued waste injection would require the installation of at least one new injection well and a larger network of observation wells.

\section{CONSTRUCTION AND OPERATION OF} EXPANDED INJECTION SYSTEM

The second injection well, I-7A, was drilled approximately $2,500 \mathrm{ft}$ (762 m) northeast of injection well I-6 (fig. 9). The second injection well was to be located at the present site of observation well 7; however, the permeability was too low for injection at this site and well 7 was completed as an observation well. During the development of well I-7A, waste and gas were pulled into the well. The gas was accidentally ignited by welding equipment, and later analysis by Hercules Inc. indicated the gas to be predominantly methane. Identification of formic acid in water samples confirmed the presence of waste.

Waste injection through well I-7A began in May 1971 at an average rate of $120 \mathrm{gal} / \mathrm{min}(454 \mathrm{l} / \mathrm{min})$, and injection of waste through well 5 ceased. By October 1971 , this new well was not accepting all the waste within the specified pressure limit, and waste injection was resumed in well 4 . Waste injection continued through both well 4 and injection well I-7A until the termination of injection in December, 1972.

The spacing of the second observation-well network installed to monitor waste movement from both the old and new injection wells was 10-15 times the distance used in the original network. Observation wells 11,12 , 14,15 , and 16 were installed during the period from May 1971 to May 1972, to monitor pressure and waste movement in the injection zone. Observation wells 8 and 9 , which were completed into the $700-\mathrm{ft}(213 \mathrm{~m})$ aquifer, were operational when the second injection well was completed.

In December 1971, waste was detected in well 9 concurrent with an increase in pressure, indicating the leakage of waste into the $700-\mathrm{ft}$ aquifer at the new injection site. This leak apparently was through the annular space around the casing of well I-7A. Pressure decreases in well 5 during December 1971, and in well 2 during March 1972, indicated that these wells also had possibly become channels for leakage of the waste into shallower zones. Wells 2 and 5 were later sealed with cement to prevent leakage, but well I-7A has not yet been sealed (April, 1974).

Figure 9 shows the well system, the reduced pressure surface of the injection aquifer, and the approximate limits of waste travel in October 1972. At this time, the areal extent of the waste in the subsurface does not coincide with the pressure surface because although the major quantity of waste was injected 
through wells I-6, 4, and 5, the highest injection pressure at this time was at well I-7A thus biasing the pressure surface to the northeast of the wastecontaminated area. The waste had apparently passed well 14, about $1,500 \mathrm{ft}(457 \mathrm{~m})$ north of the initial injection site, by the time it was completed, and also had passed well 15, about $3,000 \mathrm{ft}(914 \mathrm{~m})$ west of the initial injection site. During August 1972, the waste was detected in Well 11 as indicated by the dissolved organic carbon (DOC) content, which has proved to be
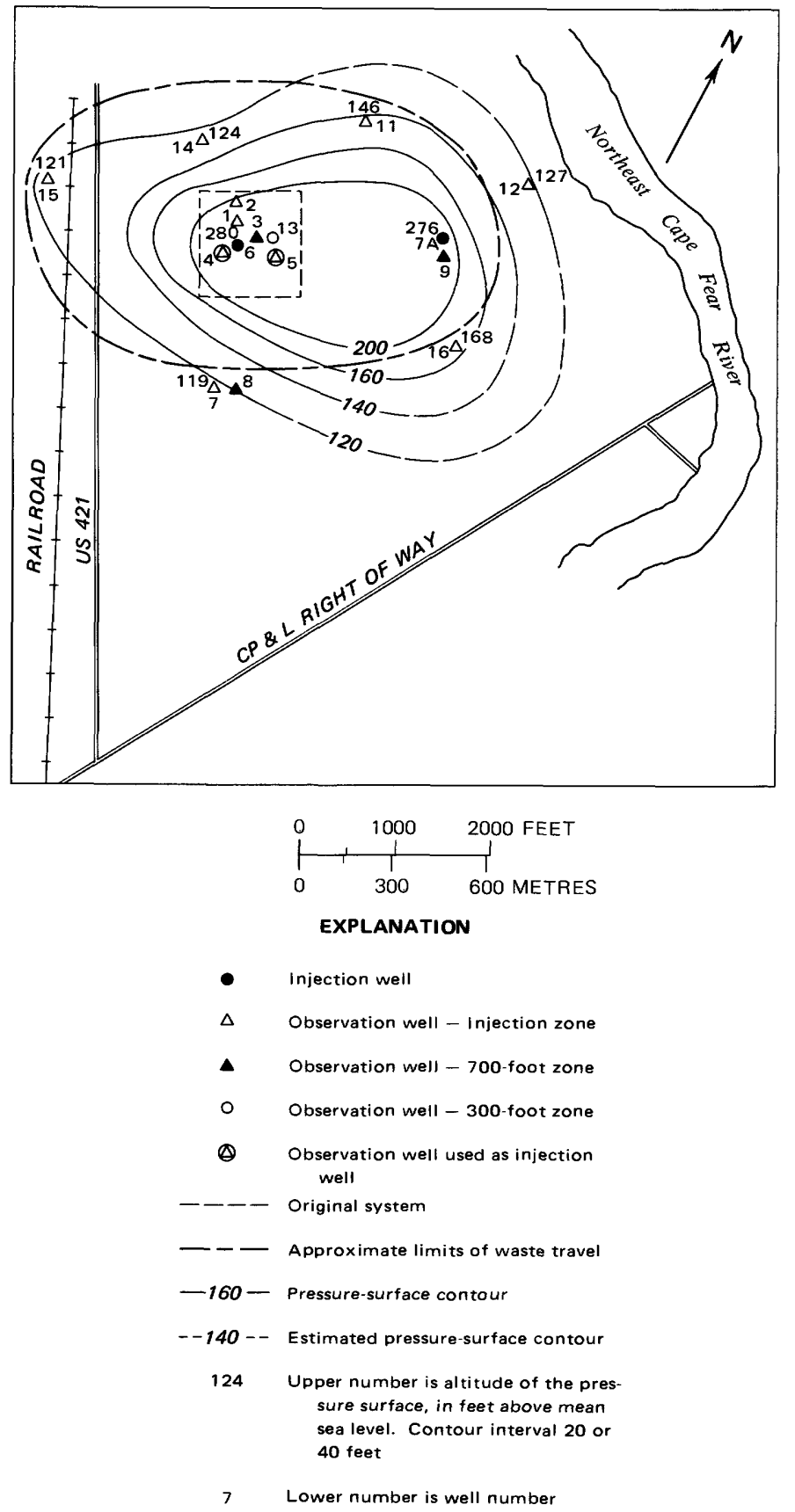

FIGURE 9.-Map of pressure surface and approximate limits of waste travel, October 1972. the best index for monitoring waste movement in the subsurface at this site.

In July 1971 the North Carolina Office of Air and Water Resources stipulated that the waste-injection permit would not be extended beyond the July 1, 1973 deadline. Therefore, in November 1972, a conventional surface waste-treatment facility was completed by the company and the injection of the waste was gradually reduced as the new facility was placed in operation. During December 1972, injection of waste ceased, although injection of freshwater continued at a rate of about $15-20 \mathrm{gal} / \mathrm{min}(57-76 \mathrm{l} / \mathrm{min})$ in both wells I-7A

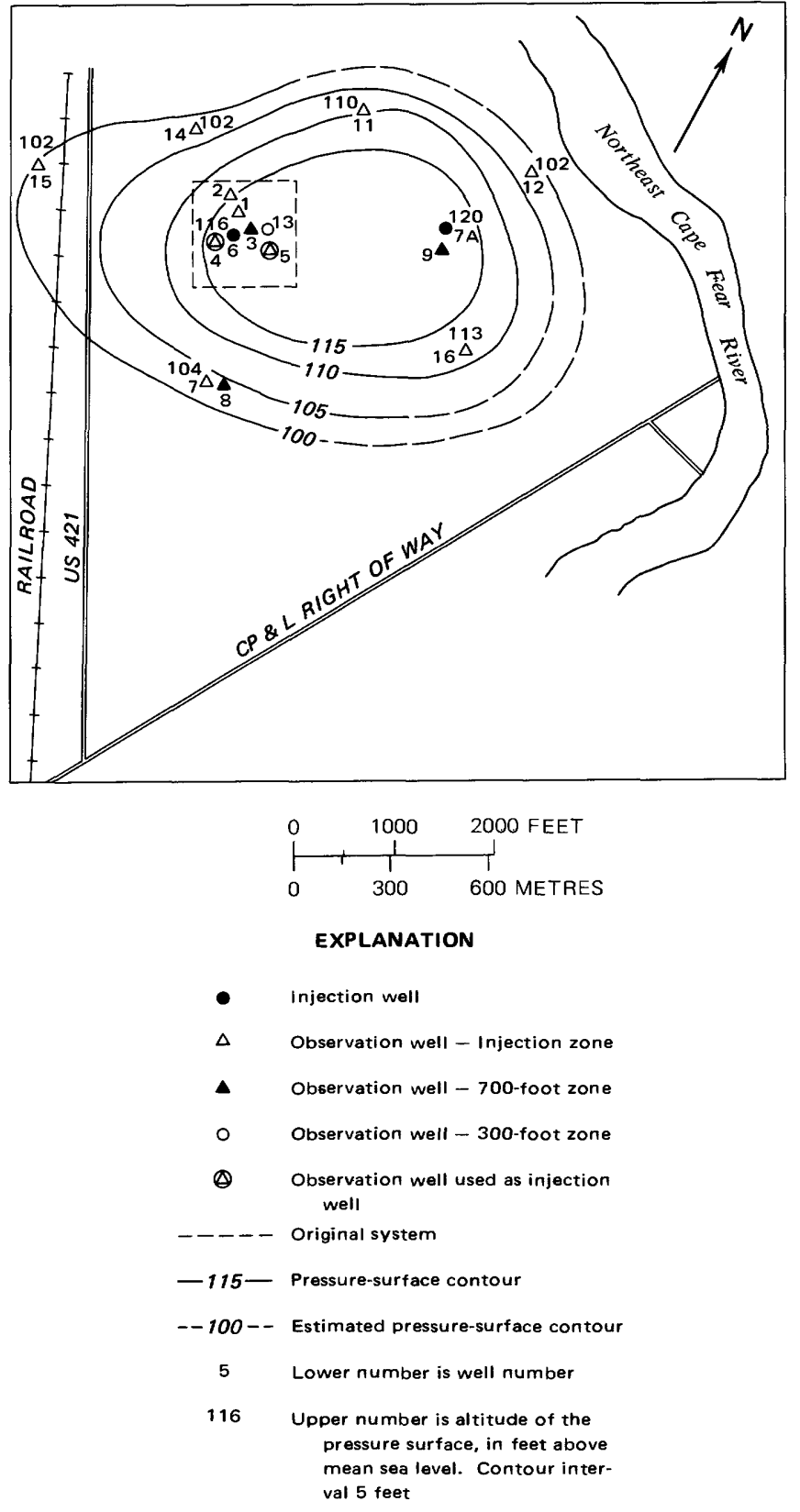

FiguRe 10.-Map of pressure surface with no injection, April 1973. 
and 4 to maintain both wells operable in case they would be needed for waste injection before July 1973 . Injection of freshwater was stopped for a period of about 9 days in March and April 1973, and figure 10 shows the pressure surface of the aquifer at the end of the 9-day period. Freshwater injection ceased in May 1973. At present (April 1974), waste injection through wells is prohibited by law in North Carolina.

\section{FIELD SAMPLING METHODS}

The collection of ground-water samples can best be explained by first considering the construction of observation well 14 as shown in figure 11 . The construction of this well is representative of most of the observation wells which are completed in the injection zone. Because the natural artesian head of the water in the injection zone is about $65 \mathrm{ft}(20 \mathrm{~m})$ above land surface, water samples were collected by simply opening the valve at the top of the plastic sampling tubing. The small diameter $(64 \mathrm{~mm}$ ID) sampling tubing enabled collection of a representative water sample after only a 30-minute flush period with minimal wastage discharge of ground water. Roughly three void volumes of water pass through the plastic sampling tube at a flow rate of $1,200 \mathrm{ml} / \mathrm{min}$ during the 30 -minute flush period. The twin sampling tubes were placed for the purpose of water collection from the well in the center of the screened injection zone at $935 \mathrm{ft}(285 \mathrm{~m})$ depth and from above the screened zone at $822 \mathrm{ft}(251 \mathrm{~m})$. Water samples obtained from above the screened section of the observation well were of little value as they did not represent water present in the injection zone. A 3-foot section of tygon tubing was connected to each outlet of the two sampling valves to facilitate sample collection.

Sampling methods were designed to be applicable to uncontaminated ground water as well as the concentrated waste for both organic and inorganic parameters. Dissolved organic carbon (DOC) was used to estimate the waste concentration because it is a quantitative organic parameter, and most of the organic waste constituents are water soluble. Water samples for DOC were pressure filtered on site immediately after collection through a silver membrane filter with $0.45-\mu \mathrm{m}$ (-micrometre) porosity. The DOC sample was collected in a $50 \mathrm{ml}$ glass serum bottle sealed with an aluminum-foil-covered rubber septum stopper. An extensive discussion of the merits of the DOC parameter and the method of DOC sample collection is given in a paper by Malcolm and Leenheer (1973).

Two samples were collected for standard inorganic water analysis: one litre of filtered water acidified to $\mathrm{pH} 2$ with nitric acid for analysis of the cations, $\mathrm{Al}, \mathrm{Ca}$, $\mathrm{Fe}, \mathrm{K}, \mathrm{Na}, \mathrm{Mg}$, and $\mathrm{Zn}$; and one litre of filtered non. acidified sample for analysis of the anions, $\mathrm{Cl}, \mathrm{F}, \mathrm{SO}_{4}$,

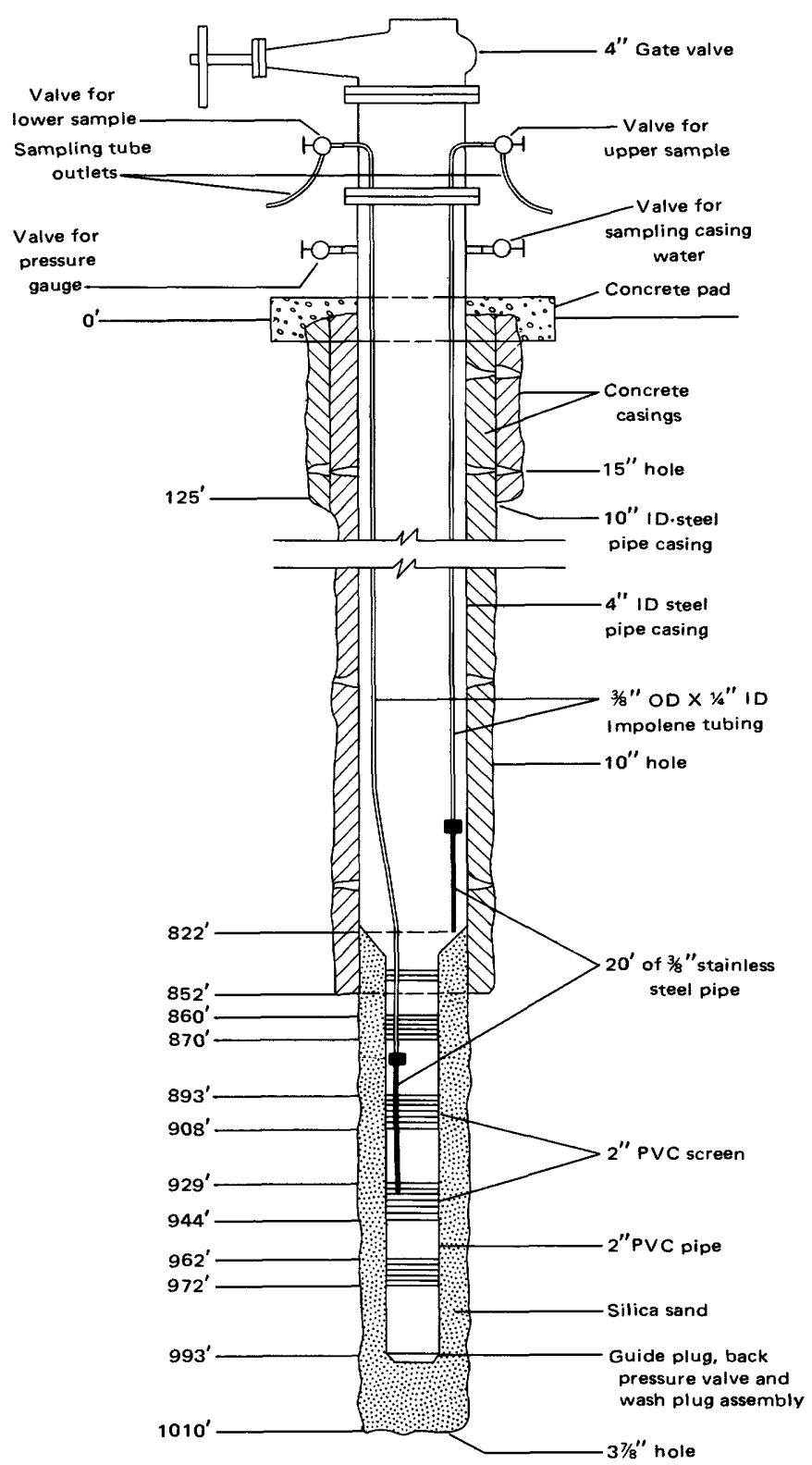

Figure 11.-Construction features of observation well 14.

$\mathrm{NO}_{2}-\mathrm{NO}_{3}$, and $\mathrm{SiO}_{2}$. The water was pressure-filtered on site through a vinyl metricell membrane filter of $0.45-\mu \mathrm{m}$ porosity in a plexiglass filtration assembly (Skougstad and Scarbro, 1968). Compressed carbonfree nitrogen was used to pressurize the filter because ferrous iron will oxidize and precipitate as ferric hydroxide during filtration if air is used to pressurize the filter. Both the acidified and non-acidified samples were collected in acid-washed, 1-litre polyethylene bottles.

A filtered 1-gallon (3.8-1) sample for trace elements was collected in an identical manner as the sample for standard inorganic analysis. After collection in an acid-washed, gallon plastic jug, high purity nitric acid 
was added to acidify the sample to $\mathrm{pH} 2$. The amount of nitric acid pipetted into the sample was recorded for the purpose of acid blank analyses.

The last type of water sample collected was a litre of unfiltered sample which was used to characterize the organic compounds. This sample was not filtered because filtration may introduce low-level adsorption and contamination problems, and filtration will also remove organic compounds of low solubility which are adsorbed and occluded on sediments. This sample was collected in a litre glass bottle previously heated to $350^{\circ} \mathrm{C}$ (Celsius) to free it of organic contamination, and was sealed with a metal screw cap with a teflon liner. After collection, the glass bottle was placed in a molded styrofoam packer for shipment, and was chilled in crushed ice to minimize sample degradation. Blank samples of uncontaminated ground water were collected as well as waste-contaminated samples to test for the presence of organic compounds such as phthalate esters originating from the plastic sampling tubing. Organic contamination arising from the sampling tubing did not prove to be a problem in comparison with the high concentrations of organic waste constituents in the contaminated ground water.

When gas was present in the observation wells, gas which effervesced from the ground water because of changes in pressure, temperature, and solubility, was collected in the following manner. The outflow from the tygon outlet tube was directed into an inverted 100 -ml graduate cylinder filled with water, and the rate of gas collection was determined over a timed period at a measured flow rate. After measurement of the rate of gas effervescence, the inlet of a $250-\mathrm{ml}$ cylindrical glass gas collector tube was attached to the tygon outlet tube, and the well water was allowed to flow through and displace the air in the collector tube which was held in the vertical position with both the inlet and outlet stopcocks open. After all the air was displaced, the gas collector tube was placed in the horizontal position, and well water was allowed to flow through the tube until 5 to $10 \mathrm{ml}$ of gas had been collected in the upper portion of the tube. The gas and water were sealed in the tube by simply closing the inlet and outlet stopcocks.

After all the samples were collected, measurements of $\mathrm{pH}$, alkalinity, and specific conductance were performed on site. Alkalinity was determined by titrating the water sample with standard acid to $\mathrm{pH}$ 4.5.The water samples were shipped air freight to Denver in a large ice chest filled with crushed ice. Most of the organic analyses were performed by the authors. The gas samples were sent by parcel post to the U.S. Geological Survey, Washington, D.C. where Donald W. Fisher performed the gas analyses. The samples for standard inorganic analysis and trace metal analysis were shipped to the Geological Survey's Central Laboratory, Salt Lake City, Utah. The samples were collected on a periodic basis by trained observers at the site.

\section{INDUSTRIAL WASTE ANALYSIS}

\section{ORGANIC ANALYSIS}

The major emphasis in the industrial waste analysis was upon the organic analysis because the chemical constituents of the waste were predominantly organic in nature. An analysis of the organic waste and methodology were used whereby one could test for the presence or absence of these organic waste compounds in waste-contaminated ground-water samples. Comparisons of the organic analyses of waste-contaminated ground water sampled at various points in the subsurface with the organic waste analysis indicated what reactions and transformatins were occurring between the waste and the injection zone for different periods after waste injection and for different distances of waste migration in the subsurface. The organic waste constituents are thought to be more reactive than the inorganic waste constituents because of ease by which they are transformed and broken down by microbiological reactions. Certain organic waste acids are thought to be active in the formation of organic-metal complexes, and thus injection of these organic complex-forming compounds causes the translocation of inorganic aquifer constituents.

The parameter used to quantify organic waste concentrations was DOC which is defined as that portion of total organic carbon which passes through a silver membrane filter of $0.45-\mu \mathrm{m}$ porosity. DOC was determined on the total carbon channel of a Beckman 915 Carbon Analyzer ${ }^{1}$ after inorganic carbon had been removed from the sample by acidifying with phosphoric acid followed by nitrogen gas purge. Losses of volatile organic carbon during the nitrogen gas purge were found to be minimal for the water-soluble organic waste constituents.

A number of analytical methods were used to identify and quantify the organic waste constituents such that nearly all of the organic carbon in the waste was accounted for. The analytical scheme used to separate and identify organic waste constituents is given in figure 12. The recovery and efficiency of each step in the analytical scheme was measured by determining the DOC which was separated or remained in the waste solution.

Steam distillation was used to separate acetic and formic acids from other dissolved constituents. A $100-\mathrm{ml}$ sample acidified to $\mathrm{pH} 1$ with sulfuric acid was steam distilled until $200 \mathrm{ml}$ of condensate was col-

\footnotetext{
1 The use of brand names in this report is for identification purposes only and does not imply endorsement by the U.S. Geological Survey.
} 
lected. Recovery studies with acetic and formic acid standards indicated that $\mathbf{5 5}$ percent of the acetic acid and 45 percent of the formic acid was steam distilled. The $\mathrm{pH}$ of the distillates was adjusted to $\mathrm{pH} 10$ with sodium hydroxide to render the acetic and formic acids non-volatile, and the samples were concentrated by evaporation on a hot plate.

The concentrates were acidified with concentrated phosphoric acid and injected into a Varian Aerograph 2700 gas chromatograph equipped with a flame ionization detector. The column was glass $(4 \mathrm{ft} \times 2 \mathrm{~mm}$ I.D.) and was packed with 100/120 mesh Porapak Q coated with 3 percent phosphoric acid. The gas chromatogram showing the separation of acetic and formic acids is given in figure 13. Formaldehyde, methanol, and $p$-toluic acid in the waste were also found to be steam volatile, but these compounds did not interfere in the quantification of acetic and formic acid by gas chromatography. A more complete discussion of a new method for the gas chromatographic analysis of acetic and formic acid is given in a report by White and Leenheer (1975).

The majority of the organic waste constituents were identified and measured in ethyl ether extracts. A $100-\mathrm{ml}$ sample was first adjusted to an alkaline $\mathrm{pH}$ by adding $3-5 \mathrm{~g}$ of sodium carbonate. Extractable bases and neutral compounds were then extracted by two successive $100-\mathrm{ml}$ portions and followed by one $50-\mathrm{ml}$ portion of ether. All of the extractions were performed in a $500 \mathrm{ml}$ separatory funnel. The extracts were collected in a 250-ml Erlenmeyer flask and dried with 40 $\mathrm{g}$ of anhydrous sodium sulfate for four hours. Organic acids were extracted in an identical manner using the same samples which were previously extracted for neutral and basic compounds after acidification to $\mathrm{pH} 1$ with concentrated sulfuric acid. Recovery studies using

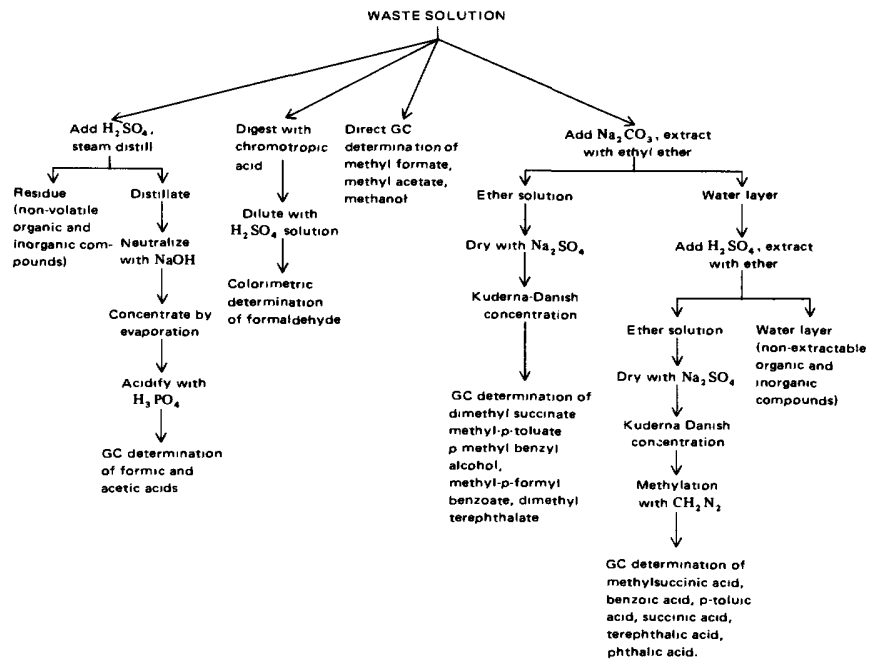

FIGURE 12. - Analytical scheme of organic waste analysis.

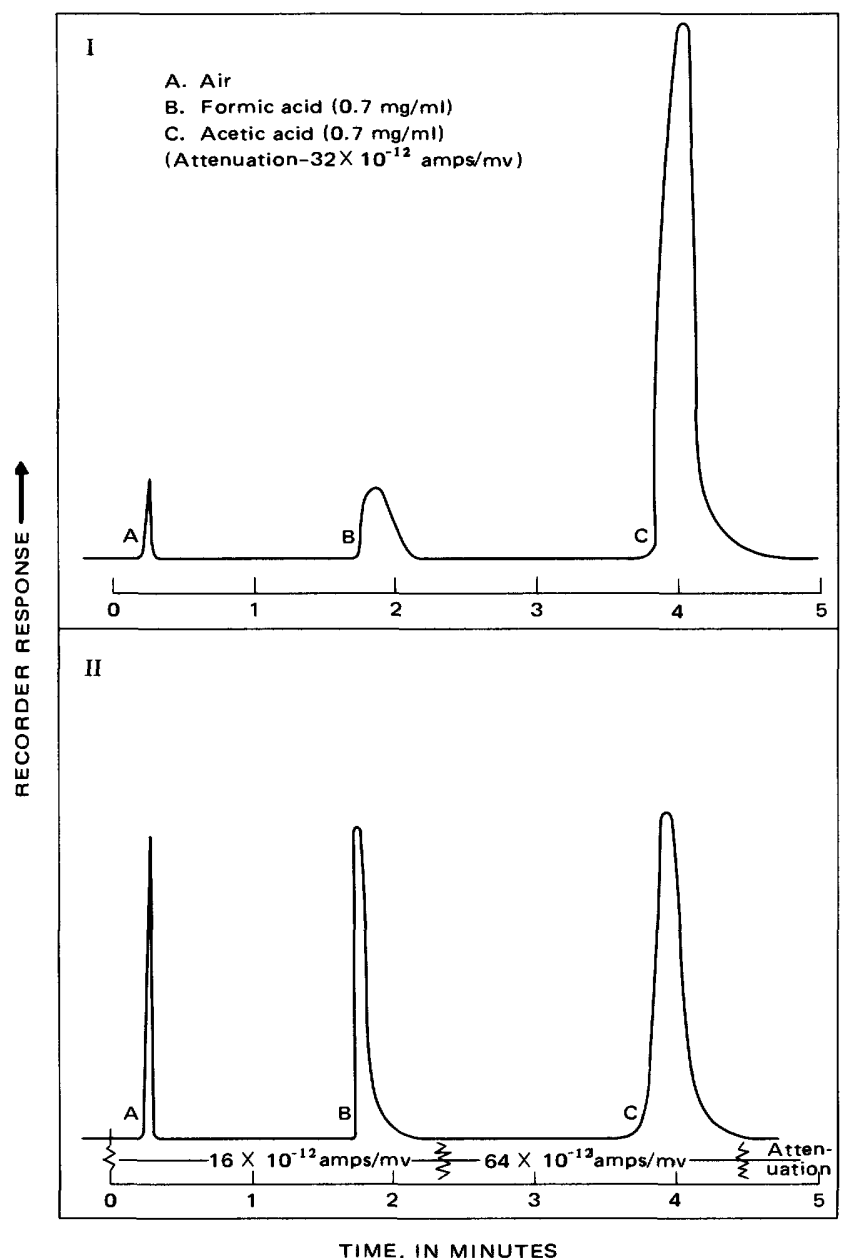

FIGURE 13. - Gas chromatogram of acetic and formic acids.

standards indicated that this ether extraction obtained 86 to 98 percent of the compounds of interest in the gas-chromatographic analysis.

The ether extracts were concentrated by $250 \mathrm{ml}$ Kuderna-Danish evaporative concentrators equipped with 3-ball Snyder columns. The concentrators were placed in a fluidized-bed sand bath at $69^{\circ} \mathrm{C}$. A time period of 30 minutes was required to concentrate 250 $\mathrm{ml}$ of ether to $5 \mathrm{ml}$. The ether concentrate containing the neutral and basic compounds was directly injected into the gas chromatograph for analysis. The concentrate containing the organic acids was esterified with diazomethane to produce the methyl esters of the organic acids. The methyl esters of the waste organic acids possessed sufficient volatility for gas-chromatographic analysis whereas the free organic acids, with the exceptions of acetic and formic acids, are nonvolatile. The methylation procedure using diazomethane is given in the Methods Manual for Analysis of Organic Substances in Water (Goerlitz and Brown, 1972, p. 37).

The majority of organic compounds extracted by 
ethyl ether were found in the acid extract. A $10 \mathrm{ft} \times$ $2 \mathrm{~mm}$ I.D. glass column packed with 10 percent diethyleneglycol succinate on Gas-Chrom $Q$ was used to separate the esterified acids in the methylated acid extract. The gas chromatogram is shown in figure 14 of the esterified acid extract. Mass spectra were obtained on each peak of the gas chromatogram by using an equivalent column in a Finnigan GC-MS Model 150 system. The mass spectra of methyl-p-toluate and dimethyl terephthalate shown in figure 14 is correlated with the gas chromatogram by the spectrum numbers. Spectrum numbers are points in the time of the analysis where complete mass spectra can be obtained in the GC-MS system. "Background spectra" were subtracted
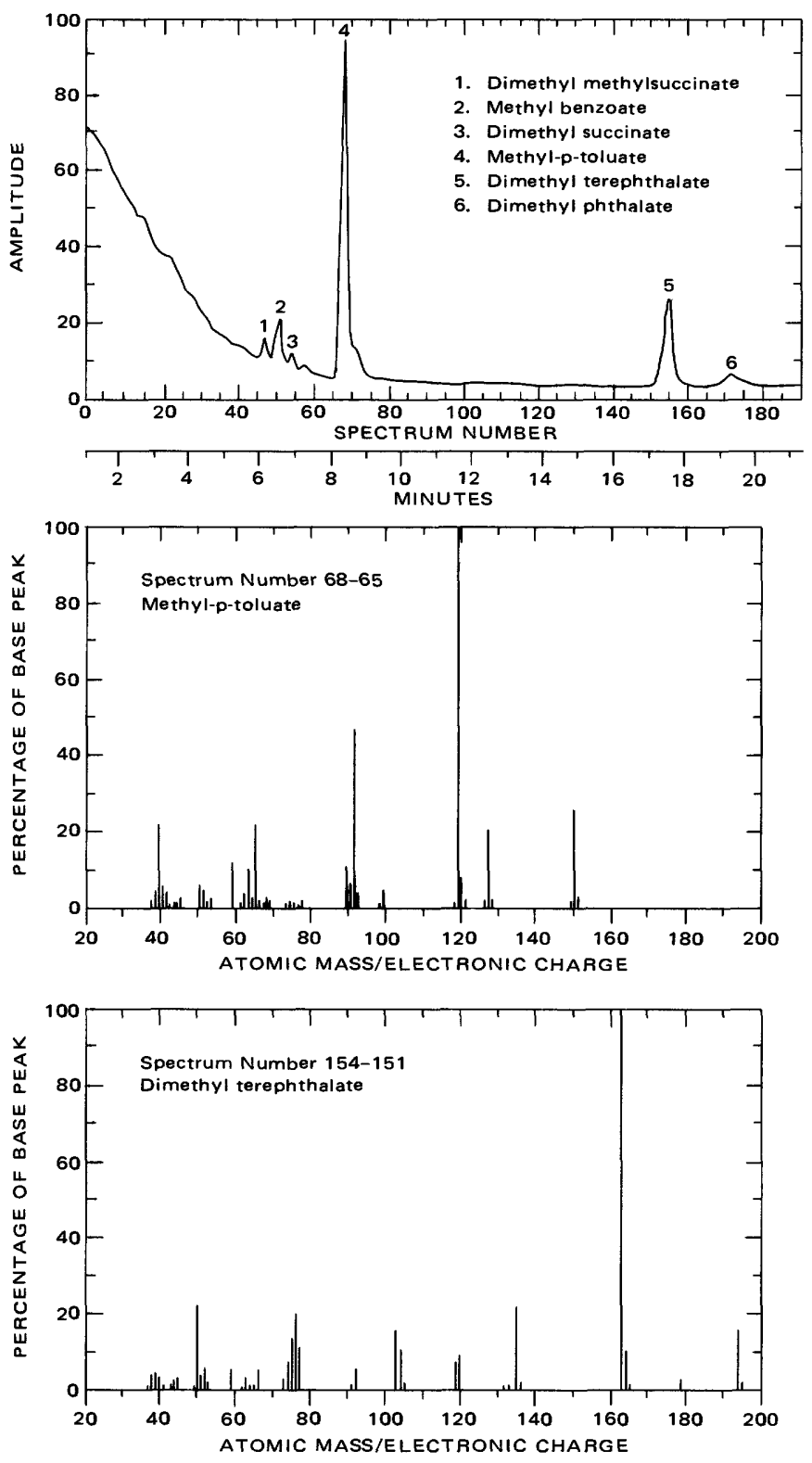

FTGURE 14.-Gas chromatogram and mass spectra of methylated-acid ether extract. by the computer in the system to give the mass spectra of the pure component. Characteristic mass spectra fragmentation patterns were used along with appropriate standards to identify the organic compounds separated in the gas chromatograph. An electronic digital integrator was used to determine the peak areas of each organic component in the gas chromatogram. Quantitative analysis was accomplished by comparison of peak areas with standard curves.

The ether extract for neutral and basic compounds was injected on the same diethyleneglycol succinate column as was used for the methylated acids, and the gas chromatogram of this fraction is shown in figure 15. There were no basic organic compounds found in the waste, and the neutral compounds identified in the ether extract accounted for less than one percent of the organic carbon in the waste.

After comparing the quantity of organic carbon identified in the steam distillate and ether extracts with the total DOC found in the waste, only about 75 percent of the organic carbon was identified. Identified organic carbon was determined by summing the products of the concentration times the percentage carbon of the determined organic constituents. Because certain volatile compounds were lost during extraction and concentration, direct injection of the waste itself into a column packed with 10 percent Ethofat on Chromosorb W was used to identify and quantify methyl formate, methyl acetate, and methanol. The gas chromatogram of this separation is shown in figure 16.

A few organic compounds do not give a sufficient response on the flame ionization detector to be measured; therefore another analytical method must be employed. Formaldehyde is such a compound and its presence was suspected by its characteristic odor in the waste residue after the other organic components had

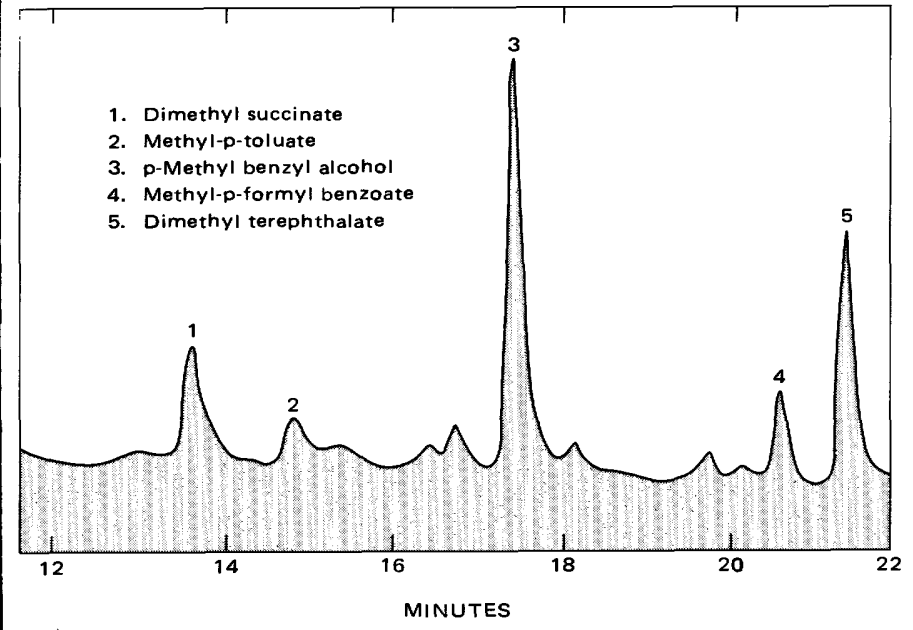

FIGURE 15. - Gas chromatogram of alkaline ether extract. 

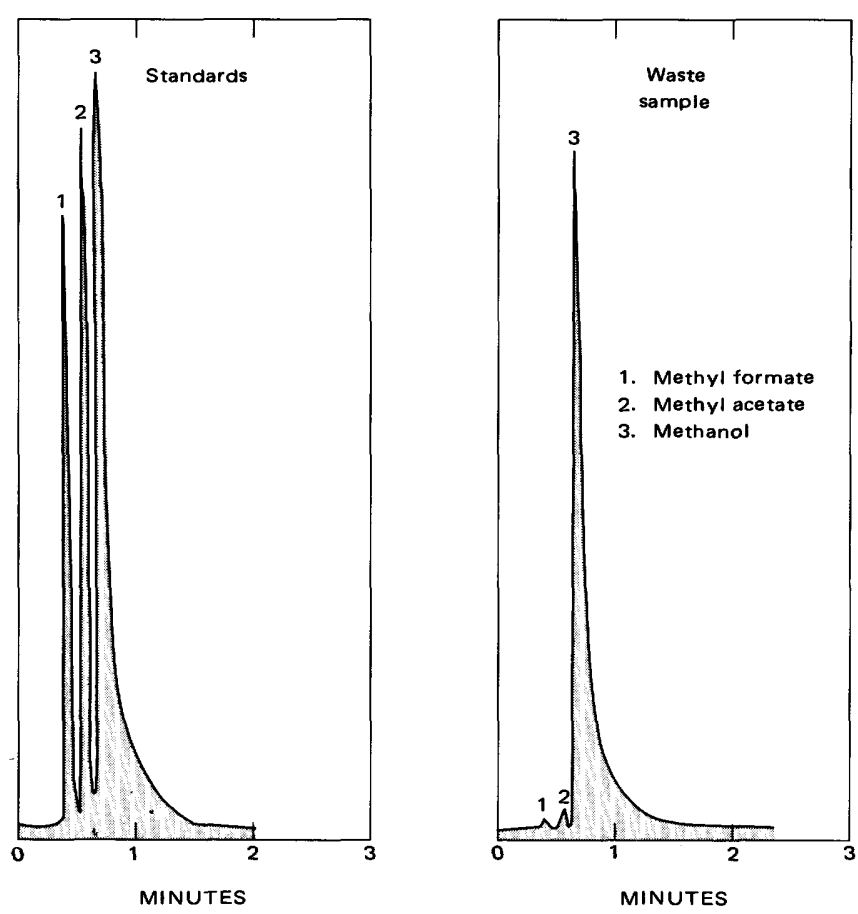

FIGURE 16.-Gas chromatogram of neutral, volatile, waste constituents.

been removed by ether extraction and steam distillation. Formaldehyde was subsequently identified quantified by its color reaction with chromotropic acid (Bricker and Vail, 1950). None of the other organic waste compounds interfere in the formaldehyde determination. Formaldehyde was the last compound to be identified in the waste, and its inclusion with the other previously identified compounds accounted for 95 percent of the DOC in the waste.

This scheme of organic analysis which was applied to the industrial waste prior to subsurface injection was also applied to ground-water samples which were contaminated by the injected waste. The only changes in the analytical scheme were that the initial sample size was larger and the degree of concentration was greater.

Three waste samples were collected during 1972-73, and the average analysis of these three samples is given in table 3 . The data of the individual analyses are given in basic-data table 20. The DOC of these waste samples ranged from 6300 to $7800 \mathrm{mg} / \mathrm{l}$; however, there were only minor variations in the relative concentrations of the various organic constituents.

All of the organic waste constituents can be thought of as reactants, impurities, byproducts, products, and (or) catalysts directly related to the industrial processes. The overall process at the Hercules plant is to oxidize $p$-xylene to terephthalic acid in the presence of methanol and acetic acid to give the primary product, dimethyl terephthalate (DMT). There is also a small formaldehyde plant which produces formaldehyde from the oxidation of methanol. In the waste analysis, methanol is a primary reactant; benzoic acid and phthalic acid most likely result from the oxidation of toluene and $o$-xylene impurities in the $p$-xylene feedstock; $p$-toluic acid, $p$-methyl benzyl alcohol, and methyl-p-formylbenzoate are incomplete oxidation products of $p$-xylene oxidation; succinic acid, methylsuccinic acid, and propionic acid are probably the fragments resulting from cleavage of the aromatic ring during $p$-xylene oxidation; formic acid is a byproduct of methanol oxidation; formaldehyde, terephthalic acid, and dimethyl terephthalate are products; and acetic acid is a catalyst. The dimethyl terephthalate product is purified after $p$-xylene oxidation and methylation by distillation and recrystallization with the extraneous organic constituents going to the waste.

Most of the organic acids found in the waste exist in chemical equilibria with the methyl, monomethyl, and dimethyl esters. These esters were generally found only in trace quantities in the waste because the aqueous waste solution tends to favor hydrolysis of the esters to the acids. No distinction was made between the monomethyl esters and the free acids for the dicarboxylic acids in the waste because both types of compounds were extracted in the acid fraction, and methylation with diazomethane converted both the monomethyl ester and free acid to the same dimethyl ester. For example, what is identified as terephthalic acid may actually be monomethyl terephthalate in the waste because methylation of both compounds will produce dimethyl terephthalate. The fact that monomethyl terephthalate is much more water soluble than terephthalic acid strongly suggests that the monomethyl ester of terephthalic acid predominates in the waste.

The organic waste analysis demonstrated that an industrial organic waste can be characterized by using a logical analytical scheme, by conducting a materials balance with DOC, and screening for organic compounds which are likely to be found in the waste as the result of the industrial process.

\section{INORGANIC ANALYSIS}

Table 4 summarizes the inorganic constituents found in the waste prior to injection. This table gives averages of two inorganic waste analyses performed by the WRD Central Laboratory, Salt Lake City, Utah, with a few miscellaneous analyses performed elsewhere. The data of the individual analyses are given in Basic Data table 21. The elements determined by atomic adsorption were $\mathrm{Al}, \mathrm{Mn}, \mathrm{Ca}, \mathrm{Mg}, \mathrm{Na}, \mathrm{K}, \mathrm{Sr}$, $\mathrm{Mo}, \mathrm{Ni}, \mathrm{Cd}, \mathrm{Cr}, \mathrm{Co}, \mathrm{Hg}, \mathrm{Zn}$, and $\mathrm{Cu}$. Automated colorimetric methods were used to determine $\mathrm{SiO}_{2}, \mathrm{Fe}$, $\mathrm{SO}_{4}, \mathrm{Cl}, \mathrm{NO}_{2}-\mathrm{NO}_{3}$, and $\mathrm{PO}_{4}$, and manual colorimetric methods were used to determine As, Se, and F. 
TABLE 3.-Average organic analysis of waste

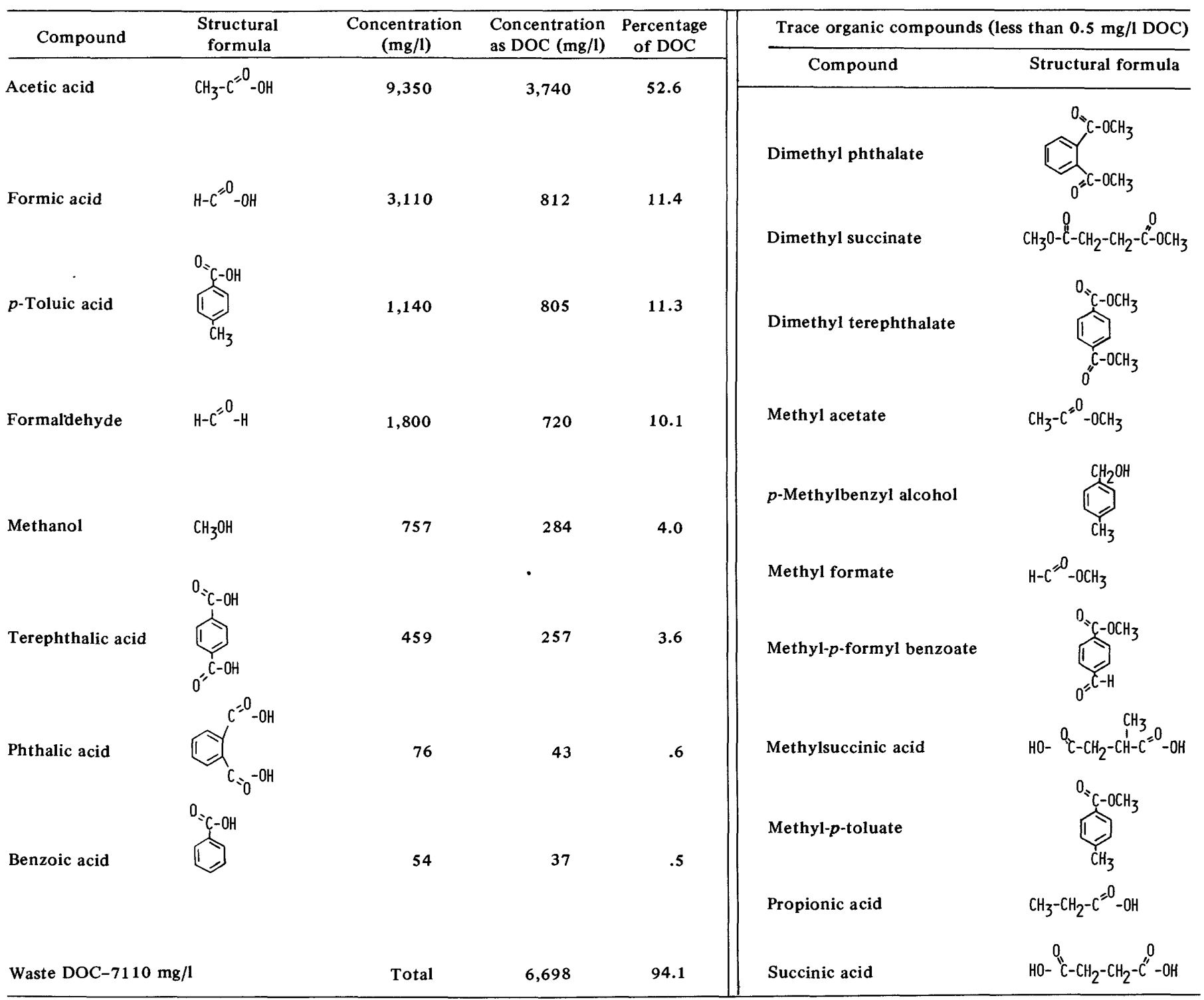

Of the inorganic parameters commonly found in $\mathrm{mg} / \mathrm{l}$ levels in ground water, only $\mathrm{Ca}, \mathrm{SiO}_{2}$, and $\mathrm{NO}_{2}-\mathrm{NO}_{3}$ were significantly higher in the waste than in the native ground water present in the injection zone.

\begin{tabular}{|c|c|}
\hline Dissolved constituent $\quad$ Concentration & Dissolved constituent $\quad$ Concentration \\
\hline Milligrams per litre & Micrograms per litre \\
\hline 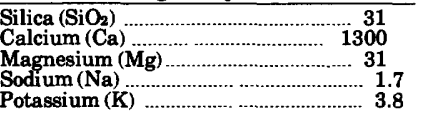 & 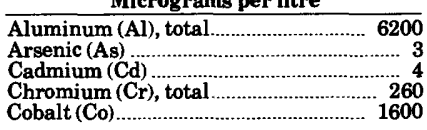 \\
\hline 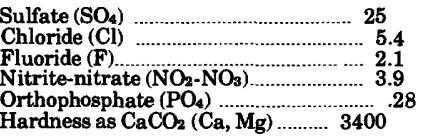 & $\begin{array}{l}\text { Copper }(\mathrm{Cu}) \\
\text { Iron }(\mathrm{Fe}), \text { total } \\
\text { Lead }(\mathrm{Pb}) \\
\text { Manganese }(\mathrm{Mn}) \\
\text { Mercury }(\mathrm{Hg}) \text {, total }\end{array}$ \\
\hline $\begin{array}{l}\text { Specific conductance } \\
\text { (micromhos at } 25^{\circ} \mathrm{C} \text { ). }\end{array}$ & $\begin{array}{l}\text { Molybdenum (Mo) } \\
\text { Nickel (Ni) } \\
\text { Selenium (Se) } \\
\text { Strontium (Sr) } \\
\text { Zinc (Zn) } \\
-\end{array}$ \\
\hline
\end{tabular}

Prior to injection, the waste moved through a settling basin, was passed through a filter to remove particles over $20 \mu \mathrm{m}$ in size, and was treated with lime to adjust the $\mathrm{pH}$ to 4 . The high levels of calcium and silica in the waste undoubtedly come from the pre-injection lime treatment in which the organic waste acids act to solubilize calcium and silica. The levels of $\mathrm{NO}_{2}-\mathrm{NO}_{3}$ can only be considered high in comparison to the native ground water in which there is practically no nitrate or nitrite. However, the presence of nitrate or nitrite in the waste may be significant because it is an available source of nitrogen for microorganisms that may be degrading the waste in the subsurface environment.

Aluminum and cobalt were found in $\mathrm{mg} / \mathrm{l}$ concentrations in the waste whereas they are usually found in $\mu \mathrm{g} / \mathrm{l}$ concentrations in ground water. The source of aluminum is probably from the pre-injection lime 
treatment, and its high concentration points out the potential of the waste for dissolution of aluminosilicate minerals. The high cobalt concentration is of interest because cobalt salts are frequently used as catalysts in the oxidation of $p$-xylene.

None of the major inorganic waste solutes-calcium, magnesium, silica, iron, aluminum, and sulfate-can serve as satisfactory tracers of waste movement in the subsurface. These solutes are common constituents of the minerals in the injection zone, and their source cannot be differentiated between the waste and the injection zone. Nitrite-nitrate are assimilated by the microorganisms in the injection zone because they are essential nutrients in limited supply. Lastly, cobalt might initially seem to be an ideal inorganic tracer for waste movement because it is an element not commonly found in significant concentrations in ground water or as a common constituent in aquifer minerals. However, cobalt is a divalent cation which participates in cation-exchange reactions with the minerals within the injection zone, and is more strongly held and retained by exchange complexes on the aquifer minerals than is calcium or sodium which are the predominant cations in the native ground water. The law of mass action in ion-exchange reactions also indicates that cobalt will be removed from the waste solution and replaced by calcium and sodium from the exchange complex because the ratio of calcium to cobalt is 100 times greater in the ground as compared to the waste, and the ratio of sodium to cobalt is 10 million times greater in the ground water than in the waste.

In summary, the dissolved ionic solutes of the industrial waste solution consist primarily of calcium and hydrogen as cations, and of acetate, formate, $p$-toluate, and terephthalate as anions. All combinations of these ionic species appear to be present in concentrations below saturation solubilities except for calcium and terephthalate which forms a precipitate when the waste solution is cooled to $20^{\circ} \mathrm{C}$.

\section{PHYSICAL PROPERTIES}

The waste prior to injection is a clear straw-colored liquid with an acrid odor which is a combination of the odors of acetic acid, formic acid, formaldehyde, and $p$-toluic acid. The temperature at which the waste was injected was about $45^{\circ} \mathrm{C}$, and when the waste was cooled to the temperature of the injection zone $\left(22^{\circ} \mathrm{C}\right)$, a white precipitate very slowly formed which was primarily the calcium salt of terephthalic acid. This precipitate may not appear until the waste is refrigerated or agitated because the waste is apparently easily supersaturated with respect to terephthalic acid and its inorganic salts.

The density of the waste at $20^{\circ} \mathrm{C}$ was determined to be $1.006 \mathrm{~g} / \mathrm{ml}$, and the density of the ground water at this temperature was $1.0142 \mathrm{~g} / \mathrm{ml}$. The injection temperature was $45^{\circ} \mathrm{C}$ and the density of the waste at this temperature is 0.9951 . This density difference may indicate that the lighter waste may tend to gravitate to the upper part of the injection zone and move outward from the injection well at a faster rate in the upper portion of the injection zone if the injection zone has a constant $T$ (transmissivity) value throughout the 150 foot injection interval. Most likely the $T$ value varies and the waste preferentially moves out into the zone of the highest $T$ value regardless of whether this zone is at the top or bottom of the injection interval.

\section{HYDROCHEMISTRY OF NATIVE GROUND WATER}

The mean chemical analyses of the native ground water found in the five water-bearing zones at the waste injection site are given in table 5. Most of the inorganic water analyses were performed in the Geological Survey's Water Resources Division Laboratories in Raleigh, N.C., and Salt Lake City, Utah. Each individual inorganic water analysis performed on water samples obtained from observation wells during the course of this study is found in basicdata tables 22-32.

Water samples from the surficial sand aquifer were collected from wells 14, 15, and 16 during well con-

TABLE 5.-Inorganic analysis of native ground water found in aquifers at waste-injection site

\begin{tabular}{|c|c|c|c|c|c|}
\hline \multirow[t]{2}{*}{ Dissolved constituent } & \multicolumn{5}{|c|}{ Depth of aquifer below land surface } \\
\hline & $\begin{array}{c}25-65 \mathrm{ft} \\
(7.6-20 \mathrm{~m})\end{array}$ & $\begin{array}{l}275-330 \mathrm{ft} \\
(84-101 \mathrm{~m})\end{array}$ & $\begin{array}{c}500-520 \mathrm{ft} \\
(152-158 \mathrm{~m})\end{array}$ & $\begin{array}{c}660-740 \mathrm{ft} \\
(201-226 \mathrm{~m})\end{array}$ & $\begin{array}{l}800-1,025 \mathrm{ft} \\
(244-312 \mathrm{~m})\end{array}$ \\
\hline \multirow{3}{*}{$\begin{array}{l}\text { phecific conductance } \\
\left.\text { (micromhos at } 25^{\circ} \mathrm{C}\right) \\
\text { Temperature }\left({ }^{\circ} \mathrm{C}\right) \\
\text { Density }\left(\mathrm{g} / \mathrm{ml} \text { at } 20^{\circ} \mathrm{C}\right) \\
\end{array}$} & 6.2 & 8.2 & 7.8 & 7.7 & 7.4 \\
\hline & $\begin{array}{l}48 \\
18.5 \\
1.0000\end{array}$ & $\begin{array}{c}8,890 \\
20.1 \\
1.0042 \\
\end{array}$ & $\begin{array}{c}19,800 \\
20.0 \\
1.0042 \\
\end{array}$ & $\begin{array}{c}27,200 \\
20.9 \\
1.0089 \\
\end{array}$ & $\begin{array}{c}31,800 \\
\quad 22.7 \\
9\end{array}$ \\
\hline & \multicolumn{5}{|c|}{ Milligrams per litre } \\
\hline $\begin{array}{l}\text { Silica }\left(\mathrm{SiO}_{2}\right) \\
\text { Calcium }(\mathrm{Ca}) \\
\text { Magnesium }(\mathrm{Mg}) \\
\text { Sodium }(\mathrm{Na}) \\
\text { Potassium (K) }\end{array}$ & $\begin{array}{r}4.9 \\
2.6 \\
1.3 \\
3.6 \\
.8\end{array}$ & $\begin{array}{r}8.1 \\
28 \\
40 \\
1,900 \\
73\end{array}$ & $\begin{array}{c}7.2 \\
130 \\
177 \\
4,520 \\
121\end{array}$ & $\begin{array}{c}9.5 \\
260 \\
267 \\
6,000 \\
182\end{array}$ & $\begin{array}{r}9.3 \\
333 \\
309 \\
6,750 \\
186\end{array}$ \\
\hline $\begin{array}{l}\text { Bicarbonate }\left(\mathrm{HCO}_{3}\right) \\
\text { Sulfate }\left(\mathrm{SO}_{4}\right) \\
\text { Chloride (Cl) } \\
\text { Fluoride (F) } \\
\text { Nitrite-nitrate }\left(\mathrm{NO}_{2}-\mathrm{NO}_{3}\right) . \\
\end{array}$ & $\begin{array}{l}6.5 \\
2.9 \\
6.0 \\
.0 \\
1.21\end{array}$ & $\begin{array}{c}578 \\
214 \\
2,610 \\
1.3 \\
.22\end{array}$ & $\begin{array}{r}354 \\
763 \\
6,970 \\
.8 \\
.05\end{array}$ & $\begin{array}{c}303 \\
595 \\
9,990 \\
.5 \\
.30\end{array}$ & $\begin{array}{c}230 \\
273 \\
12,100 \\
\quad .5 \\
.05\end{array}$ \\
\hline \multirow{4}{*}{$\begin{array}{l}\text { Orthophosphate }\left(\mathrm{PO}_{4}\right) \\
\text { Dissolved organic carbon } \\
\text { (DOC). } \\
\text { Residue on evaporation } \\
\text { at } 180^{\circ} \mathrm{C} \text {. } \\
\text { Hardness as } \mathrm{CaOO} \text { ( } \mathrm{Ca}, \mathrm{Mg})\end{array}$} & .006 & .005 & .000 & .047 & .045 \\
\hline & 2 & 1 & - & 3 & .5 \\
\hline & $\begin{array}{l}35 \\
12 \\
\end{array}$ & $\begin{array}{r}3,980 \\
231 \\
\end{array}$ & $\begin{array}{r}13,100 \\
1,050 \\
\end{array}$ & $\begin{array}{r}17,300 \\
1,740 \\
\end{array}$ & $\begin{array}{r}20,800 \\
2,110 \\
\end{array}$ \\
\hline & \multicolumn{5}{|c|}{ Mierograms per litre } \\
\hline $\begin{array}{l}\text { Aluminum (Al), total } \\
\text { Arsenic (As) } \\
\text { Barium (Ba) } \\
\text { Cadmium (Cd) } \\
\text { Chromium (Cr), total }\end{array}$ & $\begin{array}{l}109 \\
\bar{z}\end{array}$ & $\begin{array}{l}280 \\
= \\
=\end{array}$ & $\begin{array}{l}613 \\
= \\
=\end{array}$ & $\begin{array}{r}343 \\
9 \\
300 \\
60 \\
10\end{array}$ & $\begin{array}{r}242 \\
2 \\
425 \\
69 \\
18\end{array}$ \\
\hline $\begin{array}{l}\text { Cobalt (Co) } \\
\text { Copper (Cu) } \\
\text { Iron, (Fe), total } \\
\text { Lead (Pb) } \\
\text { Lithium (Li) }\end{array}$ & $\begin{array}{l}\overline{40} \\
76 \\
=\end{array}$ & $\begin{array}{r}1 \overline{173} \\
1,450 \\
=\end{array}$ & $\begin{array}{l}\bar{z} \\
\bar{z}\end{array}$ & $\begin{array}{r}2 \\
75 \\
2,640 \\
3 \\
-\end{array}$ & $\begin{array}{r}1 \\
73 \\
2,260 \\
2 \\
285\end{array}$ \\
\hline 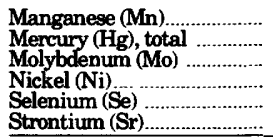 & $\begin{array}{l}12 \\
\bar{z}\end{array}$ & $\begin{array}{r}112 \\
\bar{z} \\
1,200\end{array}$ & $\begin{array}{l}\bar{z} \\
\bar{z} \\
\bar{z}\end{array}$ & $\begin{array}{r}165 \\
14 \\
2 \\
3 \\
2 \\
16,000\end{array}$ & $\begin{array}{r}356 \\
10 \\
1 \\
2 \\
8 \\
18,600\end{array}$ \\
\hline
\end{tabular}


struction, and from Company supply well C. Water was obtained between depths of 25-65 ft (7.6-20 m) below land surface, and data in table 4 for this aquifer were averaged from the individual analyses. Data were also averaged to characterize water found in the $300-\mathrm{ft}$, $500-\mathrm{ft}, 700-\mathrm{ft}$, and injection zones. Water samples from the 300 -ft zone were obtained from wells 14,15 , and 16 during construction, and from well 13 which is screened in the $300-\mathrm{ft}$ zone. The only water samples which were available to characterize water found in the 500-ft zone were obtained from wells 14 and 15 during construction. For the $700-\mathrm{ft}$ zone, uncontaminated water samples were obtained from well 8 and from well 14 during construction. Well 3 which is completed in this zone was contaminated with waste before samples were obtained. Well 9 in this zone produced water with the same chemical composition as water from the injection zone before it became contaminated with waste. Uncontaminated ground water from the injection zone was obtained from wells $7,11,12$, and 16. Wells $2,3,4$, and 5 were contaminated before samples could be obtained, and the injection zone was found to be contaminated with waste when wells 14 and 15 were completed.

On the basis of dissolved solids content determined by residue on evaporation at $180^{\circ} \mathrm{C}$, water from the surficial sand aquifer is classified as nonsaline, water from the 300 -ft zone is moderately saline, and water in the $500-\mathrm{ft}, 700-\mathrm{ft}$, and injection zones is very saline (Swenson and Baldwin, 1965). Just as dissolved solids increase with depth, so do calcium, magnesium, sodium, potassium, strontium, manganese, chloride, hardness, specific conductance, density, and temperature.

The parameters which do not increase with depth are $\mathrm{pH}$, bicarbonate, and sulfate. Bicarbonate and $\mathrm{pH}$ attain their maximum values in ground water from the $300-\mathrm{ft}$ zone, whereas sulfate content is the highest in the $500-\mathrm{ft}$ zone. Below the $300-\mathrm{ft}$ zone, both bicarbonate and $\mathrm{pH}$ decrease with depth, and sulfate content decreases with depth below the $500-\mathrm{ft}$ zone. This variation of sulfate content with depth may reflect variations in aquifer mineral constituents, bacterial reduction of sulfate in an anaerobic environment, or formation of barium and strontium sulfates. Water from the $700-\mathrm{ft}$ zone and the injection zone contains a small amount of hydrogen sulfide, as evidenced by its odor and the formation of black sulfide precipitates; therefore, sulfate may be reduced in these zones by bacterial reductive processes. Hem $(1970$, p. 168) states that water containing $1 \mathrm{mg} / \mathrm{l}$ of barium should contain no more than a few milligrams per litre of sulfate, and water containing $10 \mathrm{mg} / \mathrm{l}$ of strontium should contain no more than a few hundred milligrams per litre of sulfate. The water from the injection zone contains about $10 \mathrm{mg} / \mathrm{l}$ of strontium and about $0.4 \mathrm{mg} / 1$ of barium; therefore, the concentrations of these two constituents may well be the solubility controls on the concentration of sulfate.

The change in bicarbonate and $\mathrm{pH}$ with depth may also reflect variations in aquifer mineral constituents; however, the decrease observed in the more highly mineralized water may well be an artifact caused by the precipitation of calcite during the sampling, storage, and shipment of the samples before the analyses were performed.

The only significant concentration of nitrite-nitrate was found in the surficial sand aquifer where nitritenitrate probably infiltrates from surface sources. Phosphate concentrations were very low in all aquifers. These low concentrations of essential nutrients for microbial activity may be important in limiting the amount of microbial waste degradation in the subsurface.

Lastly, the concentration of dissolved iron and dissolved organic carbon (DOC) is of interest because these parameters are most affected by waste injection. Above $\mathrm{pH} 4.8$, the solubility of ferric iron is less than $10 \mu \mathrm{g} / \mathrm{l}$ unless there are significant concentrations of organic substances capable of forming soluble complexes (sequesterization) with ferric iron (Hem, 1970, p. 116). Because the DOC concentrations are quite low and the $\mathrm{pH}$ is slightly alkaline, it is probable that most of the dissolved iron exists in solution in the more soluble reduced form, ferrous iron.

\section{WASTE-AQUIFER INTERACTIONS}

After postulating a number of probable wasteaquifer interactions at the inception of this study in January, 1971, a two-fold study was undertaken to test the predicted transformations of the waste after subsurface injection. A site study based on analysis of water samples obtained from the observation well system was initiated in June 1971 and terminated in November 1973. A laboratory study which simulated waste injection into cores of aquifer material was conducted following the site study, and was terminated in March 1974.

\section{SITE STUDY \\ INITIAL CONDITIONS}

The water-quality situation at the waste-injection site at the beginning of this study in 1971 is shown in table 6. Water samples from wells $2,3,4$, and 5 had analyses very similar to the inorganic analysis of the waste given previously in table 2 , and all of the expected reactions had apparently stopped or slowed to rates where they were not observable. At this time, native water samples from the injection zone could be obtained from the recently constructed wells 7 and 11 , 
TABLE 6. Change in water composition with waste contamination

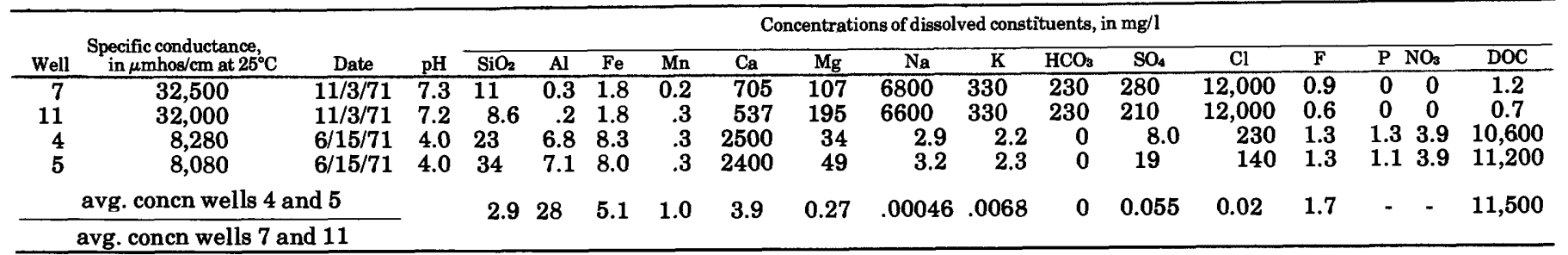

which were outside the area of waste contamination and water obtained from these wells were completely free of waste. The data in table 6 represents the two extremes between wastes and native ground water. An objective of the site study was to observe the organic and inorganic changes in the ground-water analyses in going from an uncontaminated to a contaminated state and to relate these changes to the initial hypothesized waste transformations (fig. 17) so that the initial hypotheses could be confirmed or rejected, new hypothesis made and tested, and to formulate final conclusions concerning waste transformations as presented in this report.

\section{INITIAL CONCEPTUAL MODEL OF INJECTED-W ASTE REACTIVITY AND MOVEMENT}

The initial conceptual model of the various stages of the waste in the subsurface environment is diagrammed in figure 17. This model is diagrammed for a certain point in time after the beginning of waste injection when the various components of the model have had a chance to form due to various waste-aquifer interactions. With increasing time during waste injection, the dimensions of this model will expand and move to the right. The leading volume of waste moving outwards from the injection well is mixed and dispersed with the native aquifer fluids, and this area of dispersion is called the waste front in this conceptual model. The waste area which extends between the injection well and the waste front is called the waste

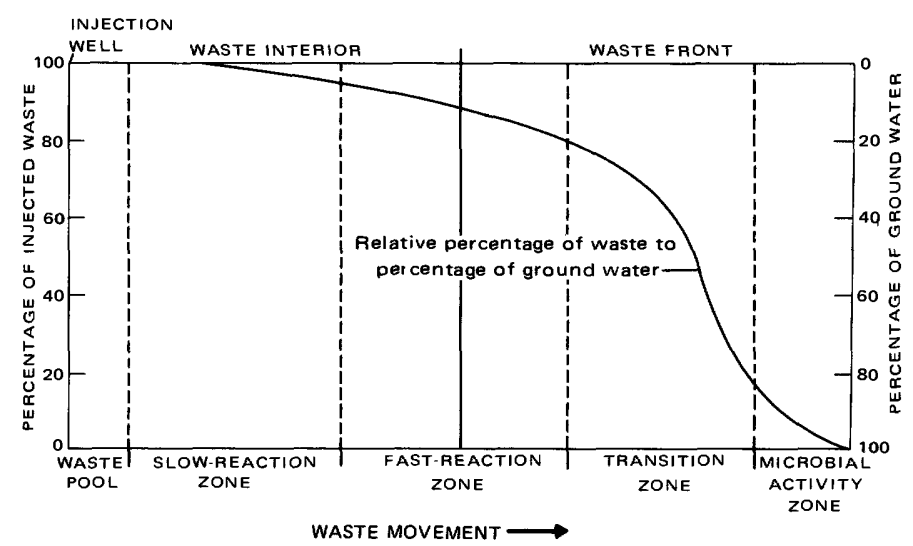

FIGURE 17.-Initial conceptual model of injected-waste reactivity and movement. interior where the native ground water has largely been replaced by the injected waste. The waste front and waste interior are divided into five zones which are labeled to describe the predominant types and mechanisms of waste transformations within each zone. Microbial waste degradation is thought to occur only at the leading edge of the waste front, and this zone is called the microbial activity zone.

The area behind the microbial activity zone is called the transition zone because it is speculated to be a region of transition between predominantly $\mathrm{mi}$ crobiological and chemical reactions which occur in the injected waste. Few chemical reactions are thought to occur in the transition zone because the reactions between the waste and the injection zone components are essentially completed by the time the waste reaches the transition zone. However, decreasing microbial activity is expected throughout this zone because of increasing concentrations of certain toxic organic compounds such as formaldehyde, and because of the disappearance of limiting nutrients such as nitrate and phosphate.

The zone trailing behind the transition zone is called the fast-reaction zone in which neutralization type reactions occur between the waste acids and the aquifer mineral constituents. Such reactions include the acidic dissolution of aquifer carbonates and iron oxide coatings. The $\mathrm{pH}$ of the waste solution changes from four at the trailing edge of the zone to seven at the boundary with the transition zone.

Reactions which occur in what is defined as the slow-reaction zone are the slow solubilization of silica, aluminum, and iron from the aluminosilicate minerals in the injection zone. The last zone which is adjacent to the injection well is called the waste pool because there are no apparent reaction or changes with time going on in the waste in this area.

\section{REACTIONS OBSERVED AT WELLS $1,2,3,4$, AND 5}

At the beginning of this study, limited data were available from the Company concerning waste contamination of wells $1,2,4$, and 5 during the first few months of waste injection. Residue on evaporation and $\mathrm{pH}$ data for water samples obtained from wells 1 and 5 during waste contamination are shown in figure 18. When the first samples were taken in July 1968, lower 


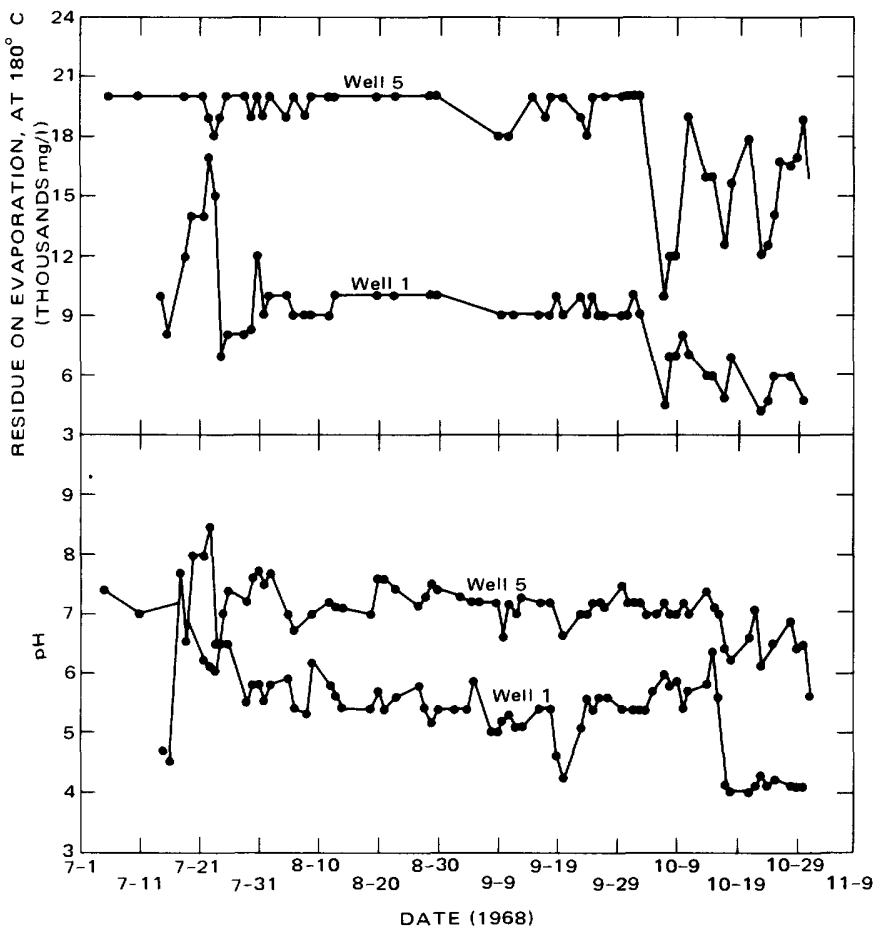

FIGURE 18.-Variations in $\mathrm{pH}$ and residue on evaporation from samples taken during observation of waste front in wells 1 and 5.

residue on evaporation values indicated that waste was already present in observation well 1 , which was only $50 \mathrm{ft}(15 \mathrm{~m})$ from injection well I-6, whereas observation well 5 , at a distance of $150 \mathrm{ft}(46 \mathrm{~m})$, was waste-free.

Observation well 5 remained waste-free until the beginning of October, when both the $\mathrm{pH}$ and residue on evaporation started to decrease. The $\mathrm{pH}$ decreased because of the acidity in the waste and the residue on evaporation decreased because the native ground water was replaced by the waste which had a lower dissolved solids content.

The fast-reaction zone in which the waste acids are neutralized is shown by the data from observation well 1 . From July 28 to October 15,1968 , the $\mathrm{pH}$ remained between 5 and 6 , during which time carbonates and iron oxides within the injection zone were reacting with the waste. The mixture of free organic acids and organic-acid salts from the neutralization reaction resulted in a pH between 5 and 6 . When the fast wasteneutralization reactions stopped, the $\mathrm{pH}$ abruptly decreased to the $\mathrm{pH}$ of the injected waste $(\mathrm{pH} 4)$ on October 18 , and has remained near this level to the present. Residue on evaporation in this well also decreased at this time to levels found in the injected waste.

Water samples collected while the waste was reacting with carbonate minerals contained large amounts of dissolved carbon dioxide, which is a product of the acid-carbonate reaction. A sample of gas which effer- vesced from a water sample collected from well 3 contained 70 percent carbon dioxide by volume as shown in basic-data table 33.

\section{REACTIONS OBSERVED AT WELL 9}

The first opportunity to observe an aquifer during the process of waste contamination occurred at well 9 in which waste suddenly appeared in high concentrations in December 1971. The first inorganic analysis determined on a sample collected on June 15, 1971 (basic-data table 25), indicated that the composition of samples obtained from this well (screened in the 700-ft zone) was essentially the same as water obtained from the injection zone. This was an indication that ground water from the injection zone had somehow leaked into the $700-\mathrm{ft}$ zone before waste injection was begun in the second injection well I-7A; therefore, it was not very surprising when waste appeared in this well after waste injection had started in well I-7A.

By June 1972, a sample collected from well 9 contained $5,800 \mathrm{mg} / \mathrm{l} \mathrm{DOC}, 78 \mathrm{mg} / \mathrm{l}$ iron, 3,900 mg/l calcium, with a $\mathrm{pH}$ of 5.8. These high concentrations of calcium and iron were indicators of waste dissolution of aquifer carbonates and iron oxides. The analysis of a sample collected almost a year later (basic-data table 25) showed that the DOC concentration had increased only slightly to $6,300 \mathrm{mg} /$, the $\mathrm{pH}$ was 4.5 , the calcium concentration had decreased to $3,100 \mathrm{mg} /$, and the iron concentration had increased to $310 \mathrm{mg} /$, which is an extremely high concentration of iron in natural water. These changes observed in two samples collected a year apart indicate that the reaction of the waste with aquifer carbonates occurs previous to, and at a higher $\mathrm{pH}$ than, dissolution of iron oxides. Carbon dioxide gas was also present in the June 1972 water sample (basic-data table 33), whereas no gas at all was present in the June 1973 sample. The very high concentration of iron in the June 1973 sample indicates that the phthalic acids found in the waste were probably forming water-soluble complexes with iron.

The indications of the carbonate and iron oxide dissolution reactions found in the $700-\mathrm{ft}$ zone tend to confirm the hypothesized reactions found in the fastreaction zone; however, these reactions occurred in an aquifer overlying the injection zone as the result of a leak, and well 9 was not regarded as a completely satisfactory sampling point to obtain information concerning reactions in the waste-injection zone.

\section{REACTIONS OBSERVED AT WELLS I I, 14, AND 15}

The major share of information concerning wasteaquifer interactions was derived from analysis of water samples obtained from wells 11,14 and 15 during the time the waste front could be sampled in these wells. Waste was found in wells 14 and 15 at the time (May 1972) they were completed in the injection zone as 
shown by the high biological oxygen demand (BOD) values determined by company analysis not given in this report. Waste appeared in well 11 in December 1972 , detected on the basis of DOC concentrations being above background levels. Well 11, 14, and 15 were sampled on a periodic basis from June 1972 to October 1973 by trained observers at the site. Data obtained on water samples from wells 11,14 , and 15 during this period are found in basic-data tables 34,35 , and 36 , respectively.

Waste was present in well 15 for only a short time after it was completed. The DOC data in basic-data table 36 shows that all except a trace of the waste was gone from this well by December 1972. The presence of acetic acid, $p$-toluic acid, and terephthalic acid definitely confirmed the presence of waste in this well during the period of elevated DOC levels.

Waste was present in well 14 in much higher concentrations than well 15 , and it did not disappear until January 1973. The significant variable parameters determined during the period when waste was present in this well are plotted in figure 19. The waste concentrations never became sufficiently high to cause detectable effects on $\mathrm{pH}$, alkalinity, specific conductance, and the inorganic anions and cations with the exception of iron. Pressure changes measured at wellhead were plotted to establish a possible relation between (1) the

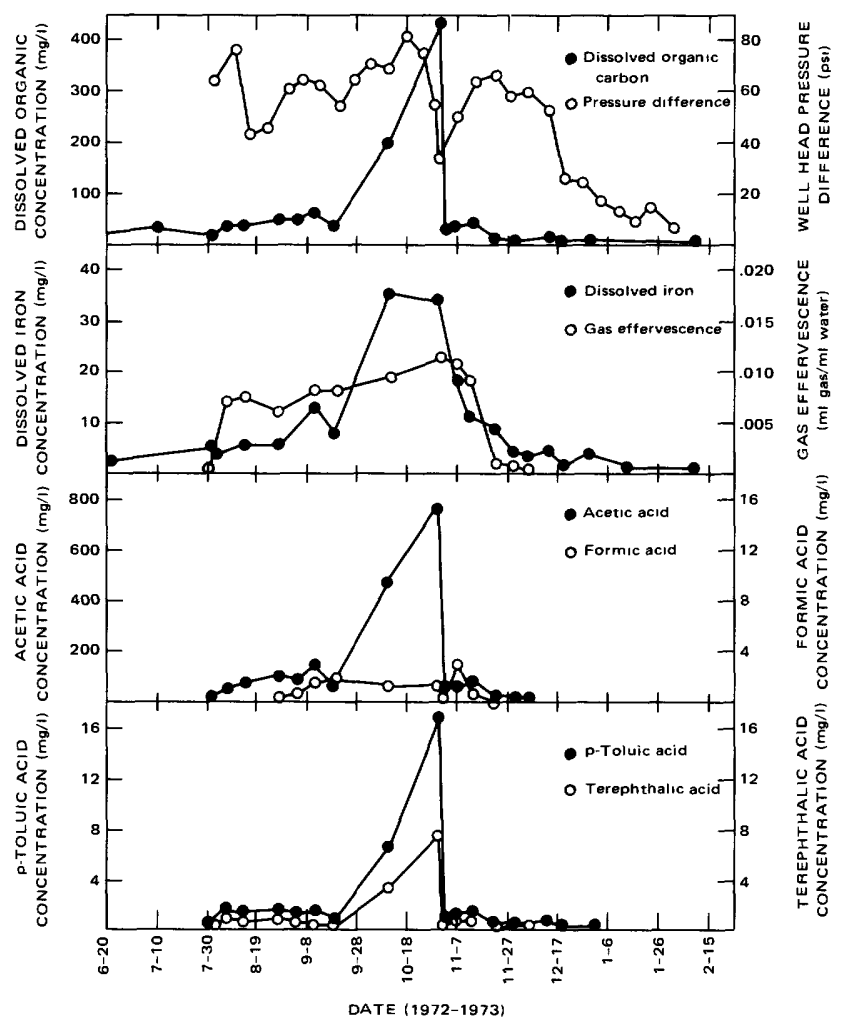

FIGURE 19.-Variables observed during passage of waste front in well 14. decreases in wellhead pressure difference in the injection zone between the injection well I-7A and well 14 and (2) the decrease in DOC in well 14. Gas effervescence was defined as the volume of gas which evolved from an equivalent volume of water under atmospheric pressure at the sampling site.

From June through October 1972, the waste content (DOC) in well 14 appeared to be increasing (fig. 19); however, the waste content abruptly decreased at the beginning of November and there was no sign of waste in the well by late January 1973. Although there were large pressure variations caused by variations in the injection rate during conversion to surface treatment, the DOC tended to decrease as the pressure difference decreased. This direct relationship between DOC and pressure difference indicated some change in the ground-water flow system with the cessation of waste injection.

The first period (June 20 to August 1) of increasing waste concentration showed only an increase in DOC as evidence of waste in the well. No gas was found in a sample collected on August 1, but gas appeared abruptly in a sample collected only 2 days later. For the period August 3 to October 31, the amount of gas continued to increase as DOC increased, and throughout November, the amount of gas decreased as DOC decreased until there was no gas present in the well early in December. A summary of the gas analyses obtained during this period is given in table 7 .

TABLE 7. - Well 14 gas analyses [N.d., not detected]

\begin{tabular}{llllll}
\hline & \multicolumn{5}{c}{ [N.d., not detected] } \\
\cline { 2 - 6 } $\begin{array}{l}\text { Date of } \\
\text { sampling }\end{array}$ & $\mathrm{H}_{2}$ & $\mathrm{~N}_{2}$ & $\mathrm{CH}_{4}$ & $\mathrm{CO}_{2}$ & $\mathrm{H}_{2} \mathrm{~S}$ \\
\hline $8-1-72$ & N.d. & 25 & 50 & 11 & N.d. \\
$8-7-72$ & N.d. & 21 & 54 & 11 & N.d. \\
$8-14-72$ & 0.2 & 36 & 40 & 11 & 0.8 \\
& & & & & \\
$10-11-72$ & N.d. & 68 & 6.0 & 4.8 & N.d. \\
$11-2-72$ & N.d. & 64 & 33 & 3.8 & N.d. \\
$11-22-72$ & N.d. & 68 & 12 & 1.5 & N.d. \\
\hline
\end{tabular}

The appearance of gas, which contained methane concentrations up to 54 percent of the total gas volume, was the first indication of anaerobic microbial decomposition of the organic waste. The following reactions show how acetic and formic acid are converted to methane by the microorganisms:

$$
\begin{aligned}
& \text { a. } \mathrm{CH}_{3} \mathrm{COOH}+\mathrm{H}_{2} \mathrm{O} \longrightarrow \mathrm{CH}_{4}+\mathrm{H}_{2} \mathrm{CO}_{3} \\
&\text { (Lawrence and } \mathrm{McCarty}, 1969) \\
& \text { b. } \\
& \text { (SHCOOH }+\mathrm{H}_{2} \mathrm{O} \longrightarrow \mathrm{CH}_{4}+3 \mathrm{H}_{2} \mathrm{CO}_{3} \\
& \text { (Siebert and Hattingh, 1967) }
\end{aligned}
$$

The most probable reason why microbial degradation of the waste did not begin immediately with the appearance of the waste is because there is a time lag during which the microbes are building up numbers large enough to significantly degrade the waste. 
The total iron concentration plotted in figure 19 is very closely related to the waste concentration. Oborn and Hem (1961) suggest that microbial activity resulting from organic substrates can indirectly increase the iron concentration by a two-stage process: (1) Microbial oxidation of waste to carbon dioxide and water lowers Eh by oxygen depletion and lowers $\mathrm{pH}$ by solution of carbon dioxide; (2) lowering of $\mathrm{Eh}$ and $\mathrm{pH}$ converts insoluble ferric iron to more soluble ferrous iron. Iron may also be brought into solution by complexation with the aromatic dicarboxylic acids found in the waste (Ringbom, 1963). A likely complexation reaction is shown below:

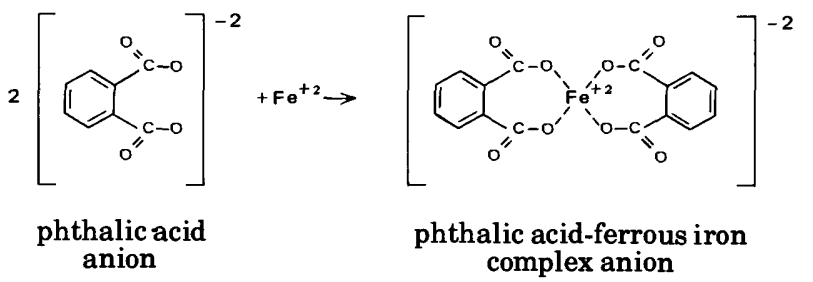

In samples collected up to September 4,1972 , there was considerable evidence of microbial sulfate reduction to sulfide in the form of black sulfide precipitates and the hydrogen sulfide gas found during the gas analysis. In later samples, sulfide precipitates and hydrogen sulfide gas were absent, and the level of dissolved iron increased, possibly because insoluble ferrous sulfide precipitates were no longer forming. Waksman (1952) showed how sulfate can be reduced with the microorganisms using acetic acid as a source of energy:

$\mathrm{CaSO}_{4}+\mathrm{CH}_{3} \mathrm{COOH} \longrightarrow \mathrm{H}_{2} \mathrm{~S}+\mathrm{CaCO}_{3}+\mathrm{CO}_{2}+\mathrm{H}_{2} \mathrm{O}$.

Methane production, iron reduction, and sulfur reduction are believed to be indicators of anaerobic microbial activity induced by waste concentrations in the ground water. These waste degradation reactions are a strong confirmation of the microbial activity zone in the waste front which was postulated in the initial conceptual model.

One of the most important aspects of this study was to define changes in the organic composition of the waste as it traveled from the injection well to an observation well. Acetic acid, formic acid, $p$-toluic acid, and terephthalic acid were determined on water samples collected from wells 11,14 , and 15 during waste contamination. Formaldehyde and phthalic acid were not found in samples obtained from these wells, and methanol was not determined because there was no way to quantitatively concentrate or extract methanol from the ground-water samples for its determination. Benzoic acid, succinic acid, and methylsuccinic acid were found in trace amounts in several samples, but were not quantitatively determined.
The concentration curves for acetic acid, $p$-toluic acid, and terephthalic acid closely follow the DOC concentration curve in figure 19 for well 14 . However, the formic acid concentration curve did not peak at the October 31 sample as did the other parameters.

To determine the changes in the relative composition of the organic waste constituents, the percentage of DOC was computed for acetic acid, formic acid, $p$-toluic acid, and terephthalic acid for each individual analysis in wells 11,14 , and 15 ; then the percentages were averaged for each well and compared with the averaged waste percentage DOC composition for these constituents. The results are shown in table 8 .

\begin{tabular}{|c|c|c|c|c|}
\hline \multirow[b]{2}{*}{ Constituent } & \multicolumn{4}{|c|}{ Percentage of DOC } \\
\hline & $\begin{array}{c}\text { Waste Before } \\
\text { injection }\end{array}$ & Well 11 & Well 14 & Well 15 \\
\hline Acetic Acid.. & 52.6 & 73.5 & 78.7 & 72.5 \\
\hline Formic Acid & 11.4 & N.d. & .4 & N.d. \\
\hline p-Toluic Acid & 11.3 & N.d. & 2.7 & 5.9 \\
\hline Terephthalic Acid......... & 3.6 & 1.9 & .9 & 1.5 \\
\hline
\end{tabular}

Of the four organic compounds determined in well 14 , the inorganic salts of acetic and formic acids are the most soluble in the ground water, and they should not be significantly adsorbed by aquifer constituents after waste injection. Acetic acid (sodium acetate) comprises the majority of the DOC found in well 14, but formic acid (sodium formate) only constitutes 0.4 percent whereas it constitutes 11.4 percent of the DOC in the injected waste. Assuming that the relative composition of the injected waste was fairly constant during the $4 \frac{1}{2}$ years of waste injection, formic acid must have decomposed during the time it traveled from the injection well to well 14 . The noncharacteristic formic acid concentration curve in figure 19 also indicates formic acid degradation within well 14. Siebert and Hattingh (1967) stated that formic acid appears to play a central part in the formation of methane, and is the organic compound most readily converted to methane by anaerobic bacteria.

The percentage composition for $p$-toluic acid and terephthalic acid also decreases in samples obtained in well 14 as compared to the injected waste (table 8). Because aromatic acids are much less biodegradable than aliphatic acids, it is likely that $p$-toluic acid and terephthalic acid are depleted during waste movement in the subsurface by adsorption on the aquifer sediments rather than being depleted by microbiological degradation. Terephthalic acid and $p$-toluic acid are much less water soluble than acetic and formic acid and therefore are more easily adsorbed.

Indications of waste in well 11 appeared in December 1972 and samples were collected for analysis 
from January through July 1973 . The waste concentration as represented by the DOC curve increased very slowly in almost a linear manner during this period as shown in figure 20. Plots of concentration versus time are also given for acetic acid, terephthalic acid, and dissolved iron in figure 20. Formic acid, formaldehyde, and $p$-toluic acid were not detected in water samples from this well. There was no gas produced or evidence of sulfate reduction. The dissolved iron concentration curve does not show any discernable correlation with the waste concentration. Dissolved iron was essentially constant while the waste concentration was increasing.

Apparently the waste concentration did not become sufficiently high to induce microbial waste degradation as was found in well 14. In well 14, the first evidence of microbial waste degradation, methane gas, occurred when the DOC concentration was at about $25 \mathrm{mg} / \mathrm{l}$. The highest DOC concentration in well 11 was only $18 \mathrm{mg} / \mathrm{l}$. Therefore, as in well 14 , microbiological waste degradation does not seem to occur below a threshold level of waste concentration.

Both the acetic acid and terephthalic acid concentration curves increase in the same manner as the DOC curve in figure 20. Acetic acid constitutes about the same percentage of the DOC in well 11 as in well

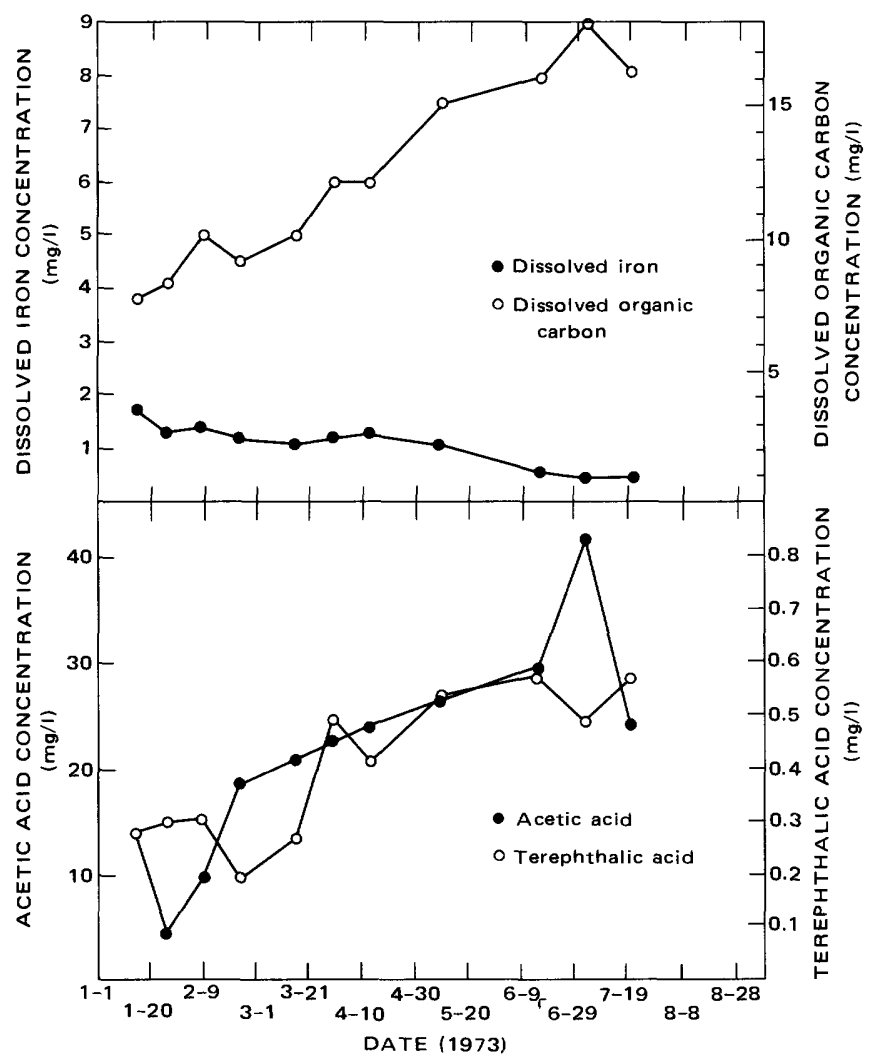

FIGURE 20.-Constituents measured during passage of waste front in well 11.
14; however, terephthalic acid was present in greater relative amounts, whereas $p$-toluic acid was not even detected (table 8 ). The relative abundance of terephthalic acid to $p$-toluic acid was reversed for the few samples collected from well 15 although the percentage of DOC due to acetic acid was about the same as for wells 11 and 14 .

The different ratios of terephthalic acid to $p$-toluic acid in each of these three wells leads one to question the assumption that the waste composition was essentially constant during the $4^{1 / 2}$ years of waste injection. It is most probable that the organic waste collected from wells 11,14 , and 15 was injected at three different points in time and contained different ratios of terephthalic to $p$-toluic acid. It is remarkable that the acetic acid contribution to DOC is about the same in these three wells as is shown in table 8. Regardless of the wide variations of the ratio of terephthalic acid to $p$-toluic acid in samples obtained from these three wells, both terephthalic and $p$-toluic acids were below concentrations at which they were found in the injected waste. It is likely that these compounds were adsorbed by aquifer sediments during their travel from the injection well to the observation well.

\section{POSSIBLE FLOW SYSTEMS ASSOCIATED WITH INJECTION ACTIVITIES}

The history of waste concentrations in wells 11,14 , and 15 suggests that the ground-water flow system associated with injection activities is very complex both vertically and areally in the injection zone. In addition, a true measure of waste concentrations could not be obtained because the $150-\mathrm{ft}(45-\mathrm{m})$ screened section of the observation wells permitted cross-circulation and dilution of waste-contaminated ground water with uncontaminated ground water, and it is very unlikely that the injected waste moved in uniform directions and rates in all permeable zones within the injection interval.

Examination of the driller's logs (Black, Crow, and Eidsness, Inc., 1971) of wells 7, I-7A, 11, and 12 show that from two to four permeable zones may exist at different points within the injection interval. Insufficient hydraulic data exist at this site to define the natural, preinjection flow system, and it is unknown whether the multiple permeable zones within the injection interval are interconnected and have the same artesian head, or whether they are independent and there is a differential, vertical distribution of head through the injection interval. The complex hydrogeology, the lack of hydraulic data, sampling limitations imposed by observation well construction, and the complexity introduced by waste injection at various rates and pressures at multiple sites all prohibit the modeling of injected-waste movement, and 
only various possibilities can be presented in this report.

A realistic hypothetical portrayal of the limits of waste movement at the upper and lower boundaries of the injection zone is represented in figure 21. The amoebic shapes of the areal waste distributions is intended to represent waste movement in directions of highest permeability. Non-coincidence of the lower boundary with the upper boundary shows that waste at the bottom of the injection zone may be moving in a different lithologic unit in directions independent of the waste in the upper part of the injection zone. The areal extent of the waste is represented to be much greater at the upper boundary of the injection zone because the specific gravity of the waste is less than the native ground water. However, if the permeability of the injection zone is greater near the lower
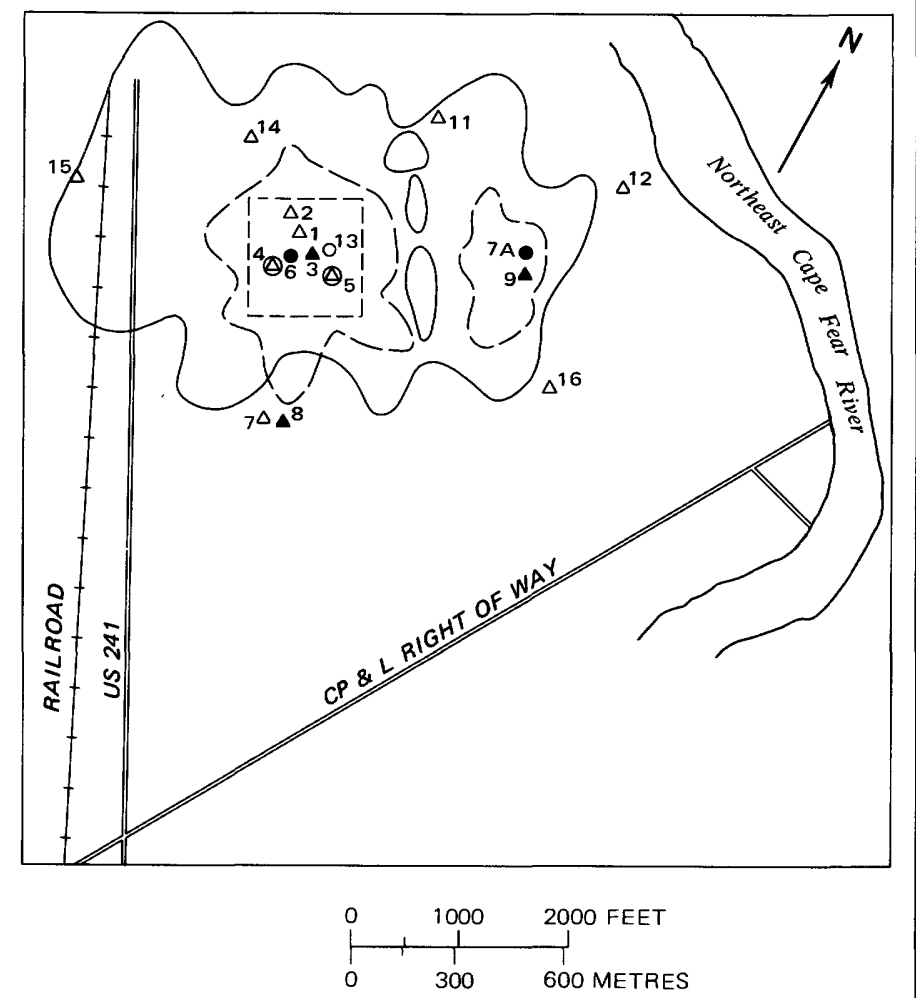

EXPLANATION

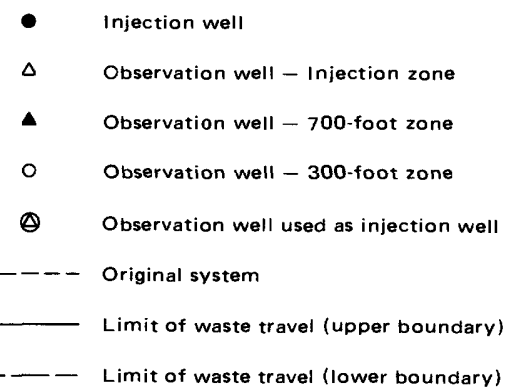

FIGURE 21.-Hypothetical areal distribution of waste at the upper and lower boundaries of the injection zone. boundary, the relative sizes of the areas invaded by the waste may be opposite from that shown in figure 21 . Because the major quantity of waste was injected through wells $\mathrm{I}-6,4$, and 5, the areal waste distribution is biased around this cluster of injection wells rather than around injection well I-7A, where a lesser quantity of waste was injected. Lastly, because waste injection occurred at multiple sites, the formation of "pools" of uncontaminated ground water surrounded by waste is also shown in figure 21 .

Changes which occurred in the waste content in samples obtained from wells 11,14 , and 15 during the 2 months after the cessation of waste injection indicated either a major change in waste distribution, or a change in water being sampled by these wells.

Therefore, the last experiment performed for the site study was to allow wells 11,14 , and 15 to flow on November 1-2, 1973, to determine if waste could be drawn into these wells. It was hypothesized that if waste did not reappear after withdrawing a limited quantity of ground water, the waste distribution had likely changed. However, if waste appeared after a short period of well flow, it is likely that the disappearance of waste with termination of injection resulted from changes in internal circulation of ground water within and adjacent to the observation well. This internal circulation is diagrammed in figure 22 . Allowing the well to flow should withdraw water from all the permeable zones within the injection zone, which is screened from 850 to $1,000 \mathrm{ft}(259-305 \mathrm{~m})$ in the observation wells.

The wells were allowed to flow by disconnecting the pressure gages and opening the 1 -inch ball valve on the wellhead assemblies. The results of this flow test are summarized in table 9.

\begin{tabular}{cccccccc}
\multicolumn{8}{c}{ TABLE 9. - Observation well flow-test data } \\
[Nd., not detected]
\end{tabular}

The flow from well 15 was stopped after 375 minutes because of concern about the withdrawn saltwater infiltrating to the supply wells. Because this well had the highest flow rate of about $60 \mathrm{gal} / \mathrm{min}(227 \mathrm{l} / \mathrm{min})$, enough water was withdrawn from this well in this period of time to pull the waste into the well. The last 
sample taken had a DOC of $47 \mathrm{mg} / \mathrm{l}$ and contained acetic acid, formic acid, terephthalic acid, and $p$-toluic acid in the amounts shown in table 7.

Well 11 initially contained a small amount of waste at the beginning of the flow period, and the amount of
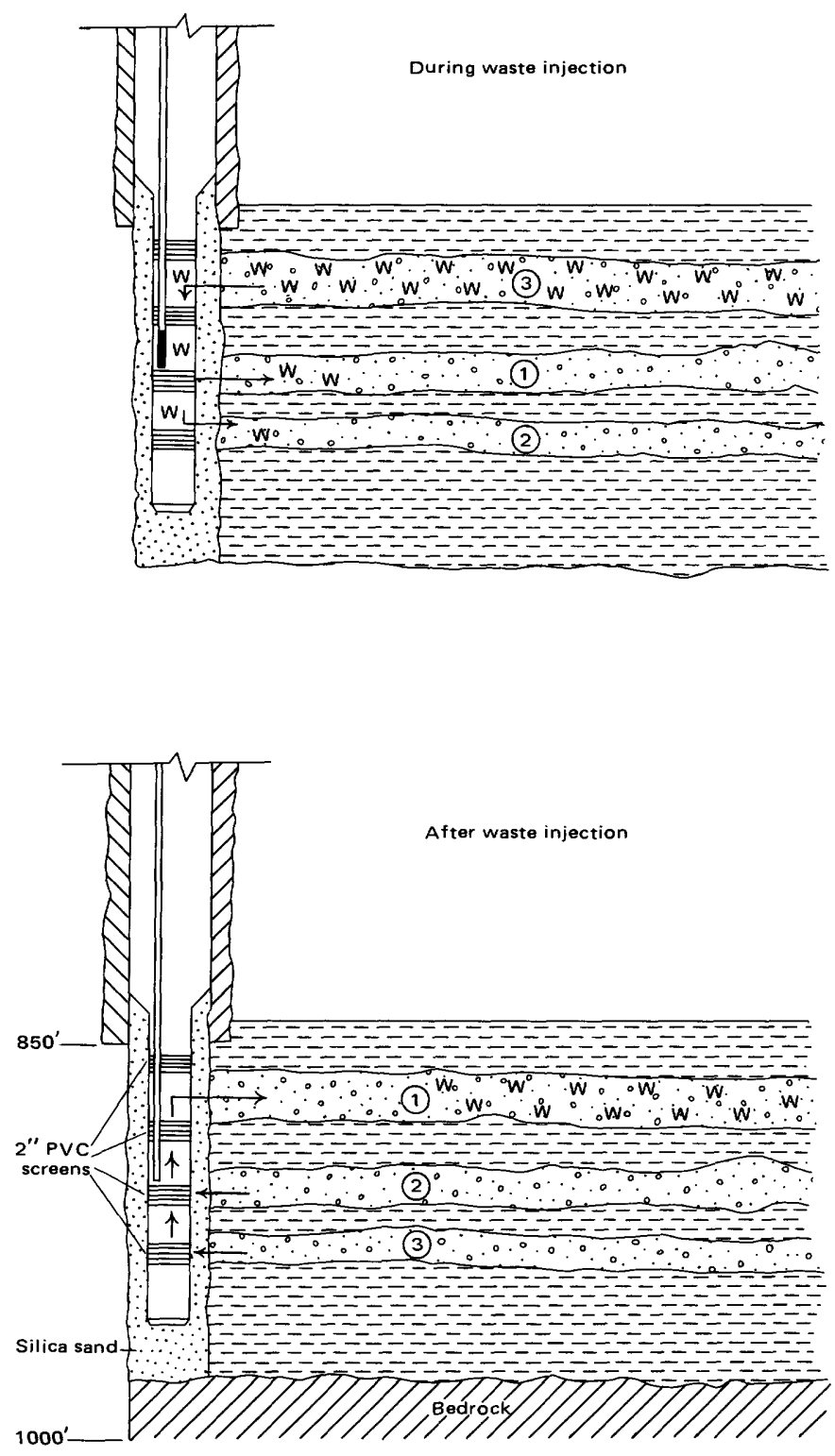

EXPLANATION

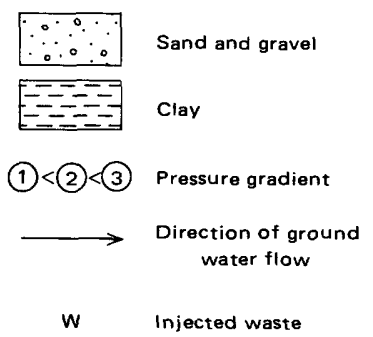

FIGURE 22.-Probable internal circulation of ground water within well 14. waste increased steadily during the flow period to the last sample, which had a DOC of $185 \mathrm{mg} / \mathrm{l}$. The relative composition of the organic constituents changed in each successive sample. Formic acid and $p$-toluic acid appeared in sample two, whereas they were not detected at the beginning of flow. By the end of the flow period, the ratio of terephthalic acid to $p$-toluic acid had reversed with $p$-toluic acid being present in the greater concentration. A gas sample obtained during the period the well was flowing contained methane at a concentration of 18 percent of the gas volume (basicdata table 33). The presence of methane indicated that microbiological waste degradation was occurring in the injection zone near well 11 , although the waste concentrations were not high enough in well 11 to induce methane formation before flow was started.

Waste was not drawn into well 14 during the period of flow. The flow rate of well 14 was only $10 \mathrm{gal} / \mathrm{min}$ ( 38 $1 / \mathrm{m}$ ) and table 7 shows that only about half as much water was withdrawn from well 14 as was withdrawn from wells 11 and 15. A gas sample was obtained which contained methane at 30 percent by volume (basic-data table 33), but this methane only indicated that waste had been present at a previous period in the injection zone. Methane apparently exists as a gas at the pressure found in the injection zone, and this gas was entrapped by the aquifer sediments and did not move away from the well with the waste when internal circulation displaced waste from the well. It is quite likely that waste would have been drawn into well 14 if it had been allowed to flow for another day and a volume of ground water equivalent to wells 11 and 15 had been withdrawn.

The results of the observation well flow experiment tended to confirm the hypothesis that waste was in the immediate vicinity of wells 11,15 , and most likely well 14. It is still possible that after injection stopped, the areal distribution of waste as shown in figure 21 changed because of the influence of the natural, regional flow system in moving the waste away from the observation wells. However, it would be unlikely that the waste would move in such a manner that it would quickly reappear when the wells were allowed to flow. In the opinion of the authors, the disappearance of waste was a result of internal circulation changes within the screened section of the observation wells, thus preventing waste from being drawn into the sampling tube. This experiment shows that in a study of this type an observation well which has its screened section opened to several water-bearing zones may not serve its purpose as an observation well because it may not yield injected waste at low-flow rates of the sampling tubes; thus when the dominant proportion of the waste is present in one of the zones, the samples obtained may not be representative. 


\section{MICROBIOLOGICAL STUDY}

The results of the microbiological study are in a report by DiTommaso and Elkan (1973), and only the significant findings will be discussed in this report.

The waste, prior to injection, was found to be void of any bacterial contamination. Likewise, samples obtained from observation wells containing high levels of waste did not support microbial flora. Approximately 3,000 organisms per millilitre were present in water samples obtained from the uncontaminated injection zone, and this count remained constant for the duration of the study. This count was somewhat high according to G. G. Ehrlich (oral commun., 1973), who cited a range of $10-1,000$ microorganisms per millilitre as representative for uncontaminated ground waters. These native organisms were isolated and identified as shown in table 10. Although anaerobic, methanogenic bacteria were found in certain waste-contaminated wells, most of the organisms isolated from the uncontaminated wells were facultative or aerobic genera rather representative of the normal microflora of aquatic environments.

The most common genera found included Agrobacterium, Pseudomonas, Proteus, Bacillus, Aerobacter, Corynebacter, Arthrobacter, and Micrococcus. In laboratory studies, isolates of these genera, either singly or in combination, were inoculated into a medium in which various dilutions of the waste served as the sole carbon and energy source. None of these well isolates were able to grow and decompose waste under these conditions. In addition to these microorganisms, a very low number of obligate anaerobes were detected. Because there is little or no organic-energy substrate in the uncontaminated injection zone, these obligate anaerobes can be present only in limited number. When a readily available carbon and energy source was added in the form of the injected waste, these anaerobes increased in number and constituted the waste-decomposing microflora.

On July 7, 1972, a 20-week study was initiated to study bacterial decomposition of waste which was occurring at that time in well 14 as was evidenced by methane gas formation. A rapid increase in the microbial population resulting from the presence of dilute concentrations of waste in well 14 occurred during the 20-week period, and this increase is shown graphically in figure 23. The colony-forming units per millilitre in the control well (well 11) remained approximately constant at 3,000 organisms per millilitre, whereas in well 14 , the population increased to approximately $1,000,000$ organisms per millilitre.

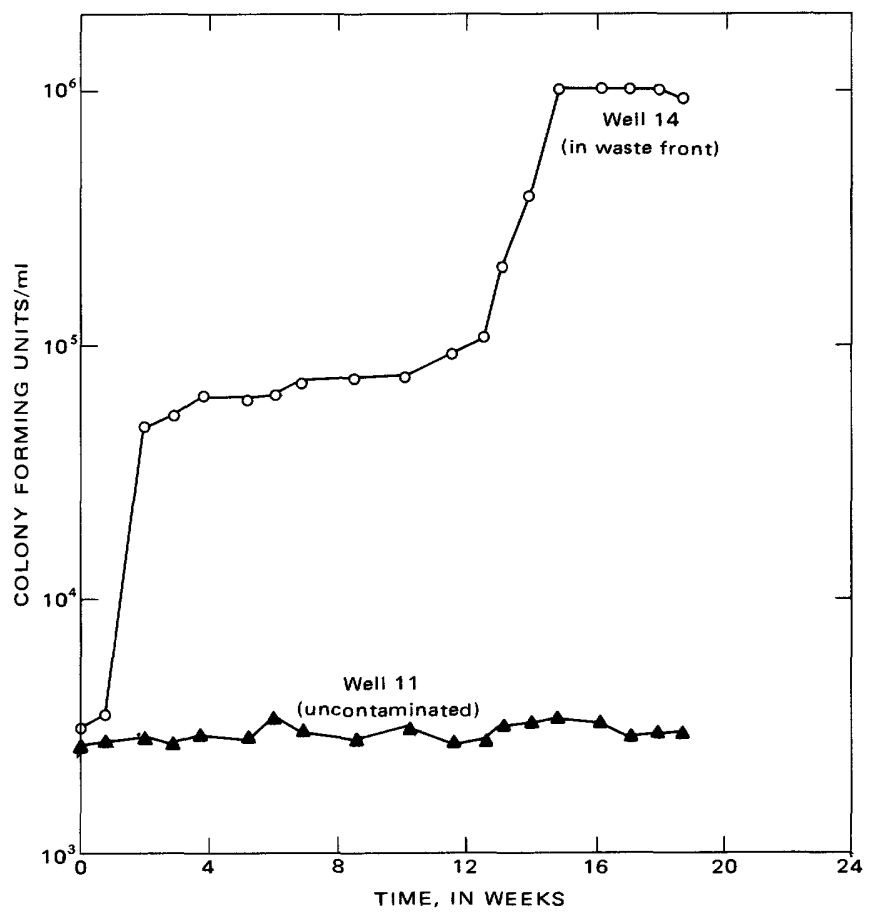

FTGURE 23.-Comparison of number of bacteria per millilitre (as colony-forming units) in waste front (well 14) and in uncontaminated aquifer (well 11).

Methanogenic bacteria were isolated in pure culture from water samples obtained from well 14 during the 20 -week study. Gram stains were performed in an attempt to classify these bacteria according to genus. Two different morphologic types were observed. The first was a gram-negative, slightly-curved rod, which was tentatively placed in the genus Methanobacte-

TABLE 10.-Identification of isolates from uncontaminated deep well 11 $\left[-\right.$, negative reaction; + , positive reaction; $A$, acid produced; $A^{*}$, weak positive reaction; $A$ G, acid and gas produced]

\begin{tabular}{|c|c|c|c|c|c|c|c|c|c|c|c|c|c|}
\hline \multirow[b]{2}{*}{$\begin{array}{l}\text { Organism } \\
\text { Identified }\end{array}$} & \multirow[b]{2}{*}{ Gram stain } & \multirow[b]{2}{*}{ Morphology } & \multirow[b]{2}{*}{ Motility } & \multirow[b]{2}{*}{$\begin{array}{l}\text { Sulfide } \\
\text { production }\end{array}$} & \multirow[b]{2}{*}{$\begin{array}{l}\text { Reduction } \\
\text { of nitrate }\end{array}$} & \multirow[b]{2}{*}{$\begin{array}{l}\text { Catalase } \\
\text { production }\end{array}$} & \multirow[b]{2}{*}{$\begin{array}{l}\text { Starch } \\
\text { hydrolysis }\end{array}$} & \multirow[b]{2}{*}{$\begin{array}{l}\text { Indole } \\
\text { production }\end{array}$} & \multicolumn{4}{|c|}{ Carbohydrate utilization } & \multirow[b]{2}{*}{ Maltose } \\
\hline & & & & & & & & & Sucrose & Mannitol & Lactose & Glucose & \\
\hline $\begin{array}{l}\text { Agrobacterium } \\
\text { Pseudomonas } \\
\text { Proteus } \\
\text { Bacillus } \\
\text { Aerobacter }\end{array}$ & $\begin{array}{l}- \\
- \\
- \\
+\end{array}$ & $\begin{array}{l}\text { Rod } \\
\text { Rod } \\
\text { Rod } \\
\text { Rod } \\
\text { Rod }\end{array}$ & $\begin{array}{l}+ \\
+ \\
+ \\
- \\
-\end{array}$ & $\begin{array}{l}- \\
- \\
- \\
-\end{array}$ & $\begin{array}{l}- \\
+ \\
+ \\
+ \\
+\end{array}$ & $\begin{array}{l}+ \\
+ \\
+ \\
+ \\
+\end{array}$ & $\begin{array}{l}- \\
- \\
- \\
+ \\
-\end{array}$ & $\begin{array}{l}- \\
- \\
- \\
- \\
-\end{array}$ & $\begin{array}{l}\bar{A} \\
\mathbf{A} \\
\overline{\mathbf{A}}\end{array}$ & $\begin{array}{l}\overline{A G} \\
A G \\
A^{*} \\
A G\end{array}$ & $\begin{array}{l}\overline{A G} \\
\mathrm{AG} \\
\mathrm{A}^{*} \\
\mathrm{AG}\end{array}$ & $\begin{array}{c}\mathrm{A} \\
\mathrm{AG} \\
\mathrm{A} \\
\mathrm{A} \\
\mathrm{AG}\end{array}$ & $\begin{array}{c}A^{*} \\
A G \\
A G \\
A \\
A G\end{array}$ \\
\hline $\begin{array}{l}\text { Corynebacter } \\
\text { Arthrobacter } \\
\text { Micrococcus } \\
\text { Pseudomonas }\end{array}$ & $\begin{array}{l}+ \\
+ \\
+\end{array}$ & $\begin{array}{l}\text { Rod } \\
\text { Rod } \\
\text { Cocci }\end{array}$ & $\begin{array}{l}- \\
- \\
-\end{array}$ & $\begin{array}{l}- \\
- \\
-\end{array}$ & $\begin{array}{l}+ \\
+ \\
+\end{array}$ & $\begin{array}{l}+ \\
+ \\
+\end{array}$ & $\begin{array}{l}- \\
+ \\
-\end{array}$ & - & $\overline{\mathrm{A}}$ & $\begin{array}{l}\text { A } \\
\text { A } \\
-\end{array}$ & $\begin{array}{l}\mathbf{A} \\
\mathbf{A} \\
\mathbf{A}\end{array}$ & $\begin{array}{l}\mathbf{A} \\
\mathbf{A} \\
\mathbf{A}\end{array}$ & $\begin{array}{l}\bar{A} \\
\mathbf{A}\end{array}$ \\
\hline $\begin{array}{l}\text { fluorescens } \\
\text { group }\end{array}$ & - & Rod & + & - & + & + & + & - & - & - & - & - & $A^{*}$ \\
\hline
\end{tabular}


rium. The other was a coccus which was gram positive and occurred in masses; it was tentatively placed in the genus Methanococcus.

Although the waste was found to be decomposable by microorganisms, the system appeared to have low efficiency. Laboratory studies showed the waste to be toxic even in moderate concentrations. The major localization of waste decomposition was found in wells located at the periphery of the waste front where the waste is highly dilute.

The site study of waste-aquifer interactions provided qualitative evidence for a number of reactions and waste-decomposition processes which have occurred in the subsurface as the result of waste injection. A laboratory study was conducted which simulated waste injection into cores of aquifer material obtained from the injection zone. The objectives of this study were: (1) To better define the waste-aquifer interactions in a quantitative manner, (2) to substantiate in the laboratory waste-aquifer interactions which were observed on-site, and (3) to test for waste-aquifer interactions which could not be observed on-site because of the construction and placement of the observation wells.

\section{LABORATORY WASTE-AQUIFER REACTIVITY STUDIES INTRODUCTION}

The disposal site at Wilmington, N.C., offered a desirable and somewhat unique situation to study the chemical and microbial aspects of subsurface waste injection because of the large number of observation wells. The movement and the reactions occurring between the waste and the disposal aquifer could be studied at various stages of the passage of the waste through or past observation wells. Most injection-well systems do not have observation wells which can be used for waste monitoring; therefore other means must be employed to gain an insight on waste movement and reactivity.

A possible means of evaluating waste reactivity is to conduct waste-aquifer reactivity studies in the laboratory. Such studies are usually conducted during the initial stages of injection-well construction to evaluate the "compatibililty" of the waste with the receiving zone. These tests are essentially engineering oriented, are usually simplistic in nature, and are somewhat analogous to comparative permeability testing with the native ground water and the waste. A positive compatibility is achieved if the permeability of the waste saturated core is the same as or greater than that of the native ground water. A negative compatibility, or a decrease in permeability of the wastesaturated core could result from precipitation or coagulation of the waste, a reduction in porosity due to dispersion and plugging with aquifer or waste solids, the swelling of aquifer solids, or other reactions which decrease the porosity of the core matrix.

The laboratory waste-aquifer reactivity tests in this study were designed to evaluate organic and geochemical reactions instead of the ordinary compatability testing such as changes in permeability and hydraulic conductivity. The general objectives of the laboratory tests were to determine (1) if the passage of the waste front through the injection zone could be simulated in the laboratory; (2) if the chemical and physical reactions which were predicted to occur between the waste and the aquifer materials in the receiving zone at the injection site would occur under laboratory conditions; and (3) to determine how well laboratory findings correlated with field data and observations.

\section{METHODS AND MATERIALS AQUIFER MATERIAL}

During the drilling of observation well 12 , cores were taken from various depths. Coring of the poorly consolidated, sandy receiving zone at $960 \mathrm{ft}(293 \mathrm{~m})$ was difficult, but several kilograms of aquifer material was obtained by screening. This material was sealed in a plastic container and remained moist until laboratory studies were conducted.

\section{CHARACTERIZATION OF AQUIFER MATERIAL}

The chemical and physical properties of the aquifer material from the receiving zone were characterized by several methods. Particle size analysis was accomplished by wet-sieving and sedimentation after mechanical dispersion at $\mathrm{pH} 9.5$ with $\mathrm{NaOH}$. Aquifer $\mathrm{pH}$ was determined on duplicate 10-gram samples in deionized water with a solid:liquid ratio of $1: 1$. The suspensions were allowed to stand for 1 hour and stirred during reading of $\mathrm{pH}$. Free iron was determined by the citratedithionite method of Mehra and Jackson (1960), total Kjeldahl nitrogen by the method of McKenzie and Wallace (1954), and organic and inorganic carbon by the method of Malcolm and others (1973).

Mineralogical analyses were accomplished by X-ray diffraction and thin-section techniques. X-ray diffraction analyses were conducted by the authors on sizefractionated, $\mathrm{K}$-saturated and $\mathrm{Mg}$-saturated samples placed on ceramic mounts by the method of Kunzie and Rich (1959). Thin-section analyses and porosity and specific gravity determinations were performed by the U.S. Geological Survey Hydrologic Laboratory in Denver, Colo.

\section{WASTE CONSTITUENT ANALYSES}

A bulk sample of the industrial organic waste was obtained from Wilmington, N.C., on November 7, 1973. The organic and inorganic analyses of this sample as 
presented in tables 3 and 4 show that the sample is representative of the injected waste. All the methods for specific organic component identification and DOC in the original waste and the reacted effluent waste from the laboratory aquifer-waste reactivity tests were performed as described in the previous method section. The identification of organic components sorbed on the aquifer material during testing was accomplished by placing 10 grams of aquifer-core material into a $250-\mathrm{ml}$ glass Erlenmeyer flask, acidification to $\mathrm{pH} 1$ with $\mathrm{H}_{2} \mathrm{SO}_{4}$, and triple extraction with $100-\mathrm{ml}$ portions of ether after 24-hour equilibration at room temperature.

Specific conductance and $\mathrm{pH}$ were determined on standardized laboratory equipment. Total iron, silica, and sulphate were determined by the authors by standardized Technicon Autoanalyzer procedures. Sodium, calcium, magnesium, and chloride were determined on the reacted waste effluent by the U.S. Geological Survey Central Laboratory in Salt Lake City, Utah.

\section{MODIFIED HASSLER SLEEVE CORE HOLDER}

The laboratory waste-aquifer reactivity studies were conducted in a modified Hassler sleeve core holder as shown in figure 24 . The core tester was designed according to the general specifications as supplied by Charles D. Haynes of Austin, Texas. The advantages of this design include the testing of large amounts of core material of various sizes and lengths, the use of rubber, plastic, or Teflon sleeves, and the implementation of confining pressure, which is analogous to overburden pressure and (or) hydrostatic pressure, if Teflon sleeves are used. This design also enables the maintenance of a pressure differential between the confining pressure and the internal core pressure.

\section{PRESSURIZATION CORE-TESTING APPARATUS}

The schematic of the pressurization core-testing apparatus is shown in figure 25. The apparatus is pressurized with nitrogen gas from a large reservoir tank. The conversion of gas pressure to hydrostatic pressure in the hydraulic separator and the liquid accumulator

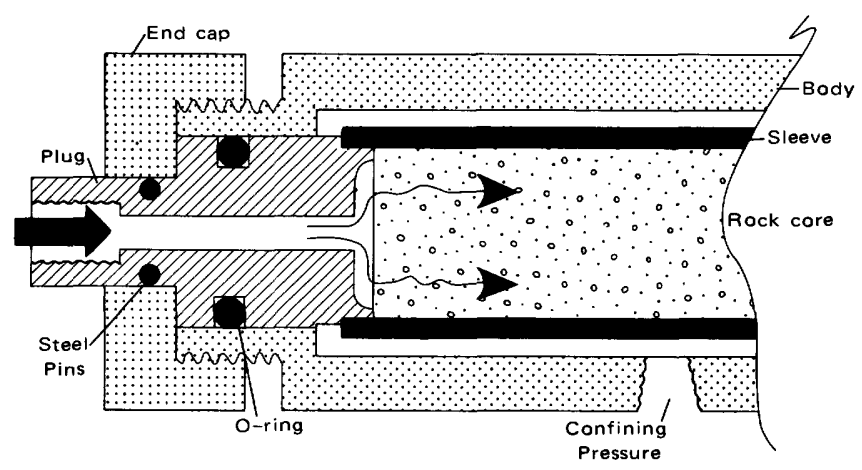

FIGURE 24.-Diagram of modified Hassler sleeve core holder.

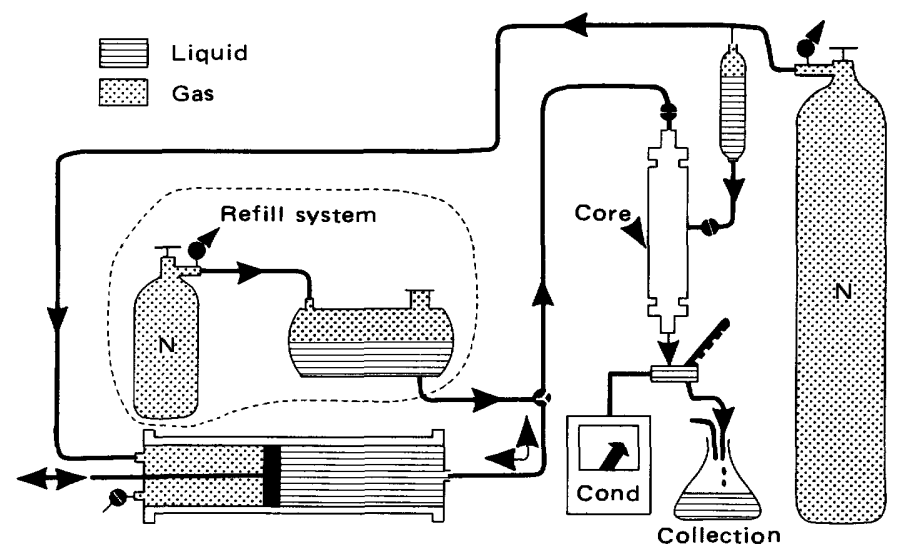

FIGURE 25.-Schematic diagram of pressurization core-testing apparatus.

tank prevents possible problems with entrained gases within the core or possible air leaks from the confining pressure reservoir into the sleeve core holder. The driving force for the movement of liquid through the aquifer material is hydraulic pressure from the hydraulic separator. The maintenance of a constant and accurate gas pressure to within 2 psi at 500 psi was accomplished by a Grove pressure regulator and a United States mirrored scaled gage.

Adequate valving arrangements enabled the refilling of the hydraulic separator from a plastic liquid refilling reservoir while maintaining a constant high pressure within the core holder. The conductivity and temperature of the core effluent were monitored with inline sensors at the outlet of the core holder. All components were connected with 0.125 inch $(3.17 \mathrm{~mm})$ stainless steel tubing except the tygon tubing for collection and monitoring of the reacted waste effluent from the core holder.

\section{EXPERIMENTAL DESIGN}

In order to accomplish the laboratory waste-aquifer reactivity experimental objectives, three experiments were conducted. Experiments 1 and 3 emphasized chemical changes which were manifested by changes in the liquid waste, whereas experiment 2 emphasized chemical reactivity which could be manifested by chemical and physical changes within the aquifer core material.

Experiment 1 was designed to simulate the passage of the waste front through an observation well or a given static point within a waste-receiving zone. The Teflon sleeve of the core holder was packed with aquifer material and the waste injected into the pressurized core at a rate of $2 \mathrm{ml} / \mathrm{hr}$ which approximated a waste movement under field conditions of $0.6 \mathrm{ft} /$ day $(0.2 \mathrm{~m} /$ day $)$.

Experiment 2 was designed to simulate changes which would be manifested within the aquifer core 
material with passage of the waste front extending into the slow-reactivity zone. To accomplish this, waste was injected into a pressurized aquifer core at a flow rate of $4 \mathrm{ml} / \mathrm{hr}$, which approximated a waste movement under field conditions of $1.25 \mathrm{ft} /$ day $(0.38 \mathrm{~m} /$ day $)$. The organic and inorganic composition of the reacted waste effluent was monitored as in experiment 1 . At the end of experiment 2 , the reacted core was fractionated into eight equal sections and analyzed for physical and chemical changes.

Experiment 3 was designed to simulate changes which a unit of the very front edge of the injected waste would undergo as it moved outward through the injection zone from the injection well. To accomplish this objective, a given amount of waste was passed or injected through successive fresh cores of aquifer material.

\section{TESTING THE PRESSURIZATION CORE-TESTING APPARATUS}

\section{LEAK TESTING}

The Hassler sleeve core holder was designed to accept Teflon sleeves. It was assumed that a confining pressure, simulating overburden pressure, greater by 150 to 200 psi (pounds per square inch) than the internal core pressure, simulating bottom hole injection pressure, would facilitate the seal between the end of the Teflon sleeve and the core-holder plug. The application of appropriate confining pressure greater than internal core pressure may also prevent channeling at the interface between the core material and the Teflon sleeve.

The core-testing apparatus was first tested with sand in the core holder. Internal core pressure and confining pressure were adjusted to 450 and $600 \mathrm{psi}$, respectively. Chloride breakthrough curves, conductivity breakthrough curves, and the drop in water level within the accumulator tank indicated leakage. With confining pressure exceeding the internal core pressure by $150 \mathrm{psi}$, the 1.5 -inch $(38.1-\mathrm{mm})$ Teflon sleeve with 0.094 -inch $(0.38-\mathrm{mm})$ wall thickness was slightly deformed, which probably added to the leakage at the plug seal. An increase in the milled thickness of the Teflon sleeve, variation in packing and tightening of the core holder, and the reduction of confining pressure to that of internal core pressure at 450 psi failed to solve the initial leakage problem.

The leakage problem was resolved by milling a 2 degree undersize taper on both ends of a thicker walled ( 0.187 inch or $4.75 \mathrm{~mm}$ ), more rigid Teflon sleeve with confining and internal pressures both at 500 psi. A sodium chloride solution conductivity breakthrough curve for medium sand in this sleeve at a flow rate of $100 \mathrm{ml} / \mathrm{hr}$ is shown in figure 26 .
After the specific conductance of the effluent salt solution was essentially the same as the input solution, the flow was stopped, and the core allowed to stand under pressure for a 15-hour period. After standing, the specific conductance of the effluent remained constant at the value of the specific conductance of the input salt solution. This test insured a leakproof system for the waste-aquifer core reactivity experiments.

During the initial pressurization of the core holder with confining and internal pressure, it is essential to increase both pressures at the same rate or possible leakage will occur at the junction of the end plug and the Teflon sleeve. It is also essential that during the refilling of the hydraulic separator with fresh waste during experiments 1 and 2 that the confining pressure and internal core pressure remain constant at $500 \mathrm{psi}$. Adequate valving isolates the core holder from the hydraulic separator. After filling the hydraulic separator, that portion of the system is first returned to 500 psi before simultaneously returning the confining and internal core pressure to the entire system.

\section{PACKING THE TEFLON SLEEVE WITH AQUIFER MATERIAL}

The aquifer material used in the laboratory studies was maintained in a moist condition (approximately 11 percent moisture by weight) in a sealed plastic container until used for experimentation. The moisture in the aquifer sample was diluted native ground water.

In preparation for sleeve packing, the top tightening ring was placed on the top end plug. The Teflon sleeve was fitted snugly to the end plug and held in place by a ring stand clamp. Small portions of representative aquifer material were packed into the Teflon sleeve with a glass rod until the sleeve was approximately

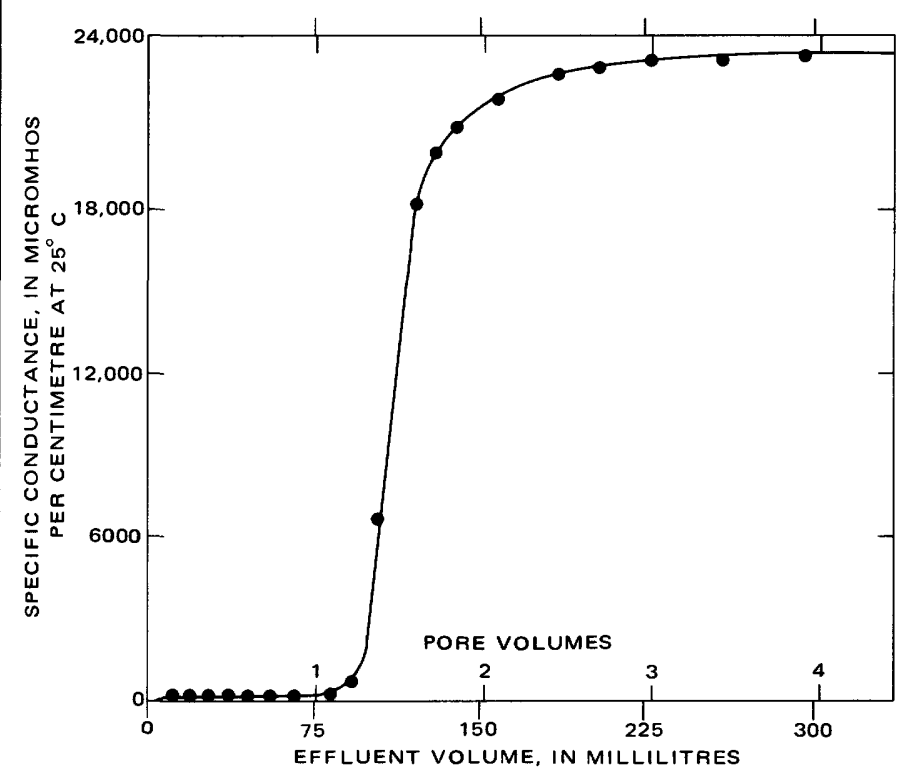

FTGURE 26.-Specific conductance breakthrough curve during leaktesting of Hassler sleeve core holder. 
one-fourth filled. In experiments 1 and 2 , native ground water was slowly introduced into the sleeve from the bottom through the end plug displacing most of the air within the column. Ground water addition was stopped when the water level reached the uppermost surface of the aquifer material. This process was repeated several times until the Teflon sleeve was filled with aquifer material. A stainless steel screen was then placed on top of the aquifer material. The packed sleeve was inserted into the body of the core holder and both ends screwed tight. The core holder with packed sleeve in place was inverted and secured into place such that the screen was then at the bottom of the column.

In experiments 1 and 2 , the packed core was equilibrated with over $500 \mathrm{ml}$ of native ground water before introduction of the industrial waste.

A minimum dilution of the injected waste by native ground water was desired in experiment 3 . The four cores in this experiment were packed only with firm tapping with a glass rod. The reacted waste from each successive pass through previous cores was slowly introduced into the bottom of the new core at low pressure. The waste slowly filled the packed core displacing the entrained air. After the column was filled, the stainless steel screen centered into place, the end plug inserted and tightened, the core holder was inverted and then pressurized.

All experiments were conducted with confining pressure and internal core pressure remaining constant at 500 psi. The same Teflon sleeve, which was 13 inches (330 $\mathrm{mm})$ in length, 1.25 inches $(3.17 \mathrm{~mm})$ inside diameter, and 0.187 inches $(4.75 \mathrm{~mm})$ in thickness, was used in all experiments. The packed core of aquifer material in each experiment was approximately 11.75 inches $(295 \mathrm{~mm})$ in length, 410 grams in weight on an oven dry basis having a specific gravity of $2.68 \mathrm{~g} / \mathrm{cm}^{3}$, and a pore space of 33 percent, which resulted in a calculated pore volume of $76 \mathrm{ml}$. The compressibility at 500 psi was approximately 2 percent. The dead volume in the effluent end of the column was approximately 5 $\mathrm{ml}$.

All laboratory experiments were conducted at room temperature, which fluctuated within $\pm 3^{\circ} \mathrm{C}$ of $25^{\circ} \mathrm{C}$. This temperature approximated the temperature within the receiving zone at the injection site.

\section{EXPERIMENT 1-KINETIC STUDY OF WASTE}

This experiment was designed to simulate the passage of a waste front through an observation well or a static point within a waste-receiving zone. Sampling during experiment 1 as shown in table 11 was conducted by collecting increment samples at 5 -hour intervals over a 6-day period at an average flow rate of $2 \mathrm{ml} / \mathrm{hr}$. The actual flow rate during the $10-\mathrm{ml}$ sample collection was approximately $15-20 \mathrm{ml} / \mathrm{hr}$. Analyses were performed on the waste effluent, but no analyses were performed on the core material at the end of the experiment.

The inorganic aspects of experiment 1 were essentially duplicated in the waste effluent monitoring portion of experiment 2 with the exception that the flow rate was $4 \mathrm{ml} / \mathrm{hr}$ with the collection of a $20-\mathrm{ml}$ sample every 5 hours. The inorganic waste effluent composition of experiment 2 will be discussed along with experiment 1.

The breakthrough data and breakthrough curves for DOC, chloride, and sodium as shown in tables 11 and 12 and figures 27 and 28 , respectively, indicate that the pore volume of each experiment is between 70 and $80 \mathrm{ml}$, which verifies the calculated value of $76 \mathrm{ml}$. The experimental pore volume is substantiated by the coincidence of the inflection point of the breakthrough curves and the 50 percent concentration factor, both of which are suggestions of pore volume. The breakthrough curve for chloride should be the same or precede the DOC breakthrough, because some organic material is sorbed, whereas chloride is not. This appears to be the case in experiment 2, but both chloride and sodium lag DOC in experiment 1 . The apparent discrepancy may be due to the fact that most parameters such as DOC, chloride, and sodium can be more accurately determined at low to moderate concentrations than at high concentrations. DOC concentrations are low and chloride concentrations are high at the initial portion of the breakthrough curve. The insensitivity of the chloride data is also suggested by large changes in $\mathrm{pH}$ and DOC while the chloride concentration remains constant.

The DOC breakthrough lags the chloride and sodium breakthrough throughout experiment 2 and for the greater portion of experiment 1 . The lag of the DOC is much more pronounced with decreasing $\mathrm{pH}$ of the effluent waste. Increased sorption of organics on the core with decreasing $\mathrm{pH}$ is expected as physical sorption and anion exchange is facilitated at lower $\mathrm{pH}$ 's.

The marked solubilization of $\mathrm{Fe}$ and $\mathrm{SiO}_{2}$ is shown in tables 11 and 12 and figures 29 and 30 . Silica dissolution precedes Fe dissolution and then reaches a steady state concentration of near $70 \mathrm{mg} / \mathrm{l}$. Silica solubilization appears to be somewhat independent of $\mathrm{Fe}$ solubilization, is independent of $\mathrm{pH}$ effects in the $\mathrm{pH}$ range of 5-7 in the experiments, and appears to be initially dependent only on the concentration of the waste. Fe dissolution on the other hand appears to be more dependent on $\mathrm{pH}$ than DOC concentration because no solubilization occurs until the $\mathrm{pH}$ of the aquifer core material is reduced to approximately $\mathrm{pH}$ 6. Below $\mathrm{pH} 6, \mathrm{Fe}$ solubilization appears to be $\mathrm{pH}$ independent, but is dependent upon the kinetics of 
TABLE 11.-Laboratory chemical data for waste-aquifer reactivity experiment 1 (flow rate $=2 \mathrm{mllh}$ ).

\begin{tabular}{|c|c|c|c|c|c|c|c|c|c|c|c|}
\hline \multirow[b]{2}{*}{$\begin{array}{c}\text { Time } \\
(\mathrm{hr})\end{array}$} & \multirow[b]{2}{*}{$\begin{array}{l}\text { Fraction } \\
\text { number }\end{array}$} & \multirow{2}{*}{$\begin{array}{c}\text { Cumulative } \\
\text { volume } \\
\text { (ml) }\end{array}$} & \multirow{2}{*}{$\begin{array}{c}\text { Specific } \\
\text { Conductance } \\
\text { ( } \mu \text { mhos/cm } \\
\left.\text { at } 25^{\circ} \mathrm{C}\right)\end{array}$} & \multirow[b]{2}{*}{$\mathrm{pH}$} & \multicolumn{7}{|c|}{ Concentration in mg/l } \\
\hline & & & & & DOC & $\mathrm{Fe}$ & $\mathrm{Si}$ & $\mathrm{Na}$ & $\mathrm{Ca}$ & Mg & Cl \\
\hline $\begin{array}{r}0 \\
5 \\
10 \\
15 \\
20\end{array}$ & $\begin{array}{l}1 \\
2 \\
3 \\
4 \\
5\end{array}$ & $\begin{array}{l}10 \\
20 \\
30 \\
40 \\
50\end{array}$ & $\begin{array}{l}31,100 \\
32,000 \\
31,200 \\
30,500 \\
30,000\end{array}$ & $\begin{array}{l}6.70 \\
7.60 \\
7.65 \\
7.30 \\
7.20\end{array}$ & $\begin{array}{r}190 \\
76 \\
170 \\
590 \\
1100\end{array}$ & $\begin{array}{l}0.3 \\
0.3 \\
0.5 \\
1.1 \\
0.6\end{array}$ & $\begin{array}{l}12 \\
13 \\
14 \\
16 \\
22\end{array}$ & $\begin{array}{l}7000 \\
7100 \\
7000 \\
7200 \\
6700\end{array}$ & $\begin{array}{l}490 \\
430 \\
450 \\
580 \\
730\end{array}$ & $\begin{array}{l}290 \\
300 \\
310 \\
310 \\
330\end{array}$ & $\begin{array}{l}12,000 \\
12,000 \\
12,000 \\
12,000 \\
12,000\end{array}$ \\
\hline $\begin{array}{l}25 \\
30 \\
35 \\
40 \\
45\end{array}$ & $\begin{array}{r}6 \\
7 \\
8 \\
9 \\
10\end{array}$ & $\begin{array}{r}60 \\
70 \\
80 \\
90 \\
100\end{array}$ & $\begin{array}{l}28,100 \\
26,900 \\
25,000 \\
22,500 \\
21,100\end{array}$ & $\begin{array}{l}7.15 \\
7.00 \\
6.85 \\
6.80 \\
6.80\end{array}$ & $\begin{array}{l}1900 \\
2500 \\
3200 \\
4100 \\
4400\end{array}$ & $\begin{array}{l}0.3 \\
1.6 \\
0.4 \\
1.4 \\
0.8\end{array}$ & $\begin{array}{l}27 \\
34 \\
39 \\
43 \\
47\end{array}$ & $\begin{array}{r}6300 \\
5200 \\
390 \overline{0}\end{array}$ & $\begin{array}{r}920 \\
15 \overline{00} \\
220 \overline{0}\end{array}$ & $\begin{array}{l}340 \\
330 \\
310\end{array}$ & $\begin{array}{r}11,000 \\
7,600 \\
5,400\end{array}$ \\
\hline $\begin{array}{l}50 \\
55 \\
60 \\
65 \\
70\end{array}$ & $\begin{array}{l}11 \\
12 \\
13 \\
14 \\
15\end{array}$ & $\begin{array}{l}110 \\
120 \\
130 \\
140 \\
150\end{array}$ & $\begin{array}{l}19,200 \\
18,000 \\
16,900 \\
15,600 \\
14,600\end{array}$ & $\begin{array}{l}6.20 \\
6.10 \\
6.10 \\
6.10 \\
5.90\end{array}$ & $\begin{array}{l}5000 \\
5600 \\
5800 \\
6100 \\
6500\end{array}$ & $\begin{array}{l}\frac{29}{48} \\
\frac{73}{23}\end{array}$ & $\begin{array}{l}51 \\
54 \\
57 \\
60 \\
63\end{array}$ & $\begin{array}{r}3090 \\
2190 \\
-\end{array}$ & $\begin{array}{r}2300 \\
= \\
=\end{array}$ & $\begin{array}{r}278 \\
238 \\
-\end{array}$ & $\begin{array}{r}4,200 \\
2,900 \\
=\end{array}$ \\
\hline $\begin{array}{l}100 \\
105 \\
110 \\
115 \\
120\end{array}$ & $\begin{array}{l}21 \\
22 \\
23 \\
24 \\
25\end{array}$ & $\begin{array}{l}210 \\
220 \\
230 \\
240 \\
250\end{array}$ & $\begin{array}{l}12,600 \\
12,700 \\
12,600 \\
12,400 \\
12,000\end{array}$ & $\begin{array}{l}\mathbf{5 . 5 5} \\
5.50 \\
5.45 \\
5.40 \\
5.35\end{array}$ & $\begin{array}{l}7200 \\
7100 \\
7400 \\
7500 \\
7500\end{array}$ & $\begin{array}{l}129 \\
139 \\
142 \\
151 \\
161\end{array}$ & $\begin{array}{l}69 \\
70 \\
70 \\
71 \\
72\end{array}$ & $\begin{array}{l}\overline{-} \\
\overline{310} \\
-\end{array}$ & $\begin{array}{l}\overline{-} \\
\overline{4} \\
\overline{-}\end{array}$ & $\frac{\overline{-}}{\overline{128}}$ & $\begin{array}{l}\bar{z} \\
\overline{353}\end{array}$ \\
\hline $\begin{array}{l}125 \\
130 \\
135 \\
140 \\
145\end{array}$ & $\begin{array}{l}26 \\
27 \\
28 \\
29 \\
30 \\
\end{array}$ & $\begin{array}{l}260 \\
270 \\
280 \\
290 \\
300 \\
\end{array}$ & $\begin{array}{l}12,500 \\
11,900 \\
12,000 \\
11,750 \\
11,600\end{array}$ & $\begin{array}{l}5.30 \\
5.30 \\
5.28 \\
5.28 \\
5.25\end{array}$ & $\begin{array}{l}7600 \\
7600 \\
7600 \\
7700 \\
7700\end{array}$ & $\begin{array}{l}167 \\
167 \\
180 \\
183 \\
202\end{array}$ & $\begin{array}{l}71 \\
72 \\
72 \\
73 \\
73\end{array}$ & $\begin{array}{r}\overline{-} \\
\overline{110}\end{array}$ & $\begin{array}{r}\overline{-} \\
4200 \\
4300\end{array}$ & $\frac{\overline{-}}{108}$ & $\frac{\overline{7}}{133}$ \\
\hline
\end{tabular}

dissolution as shown by flow rate relationships. At the high flow rate during experiment 2 , the Fe concentration reached a steady state of approximately $115 \mathrm{mg} / \mathrm{l}$. During experiment 1 at low flow rate, the Fe concentration kept increasing in a curvilinear fashion to above $200 \mathrm{mg} / \mathrm{l}$.

Total and corrected values for $\mathrm{Fe}$ and $\mathrm{Si}$ concentra-
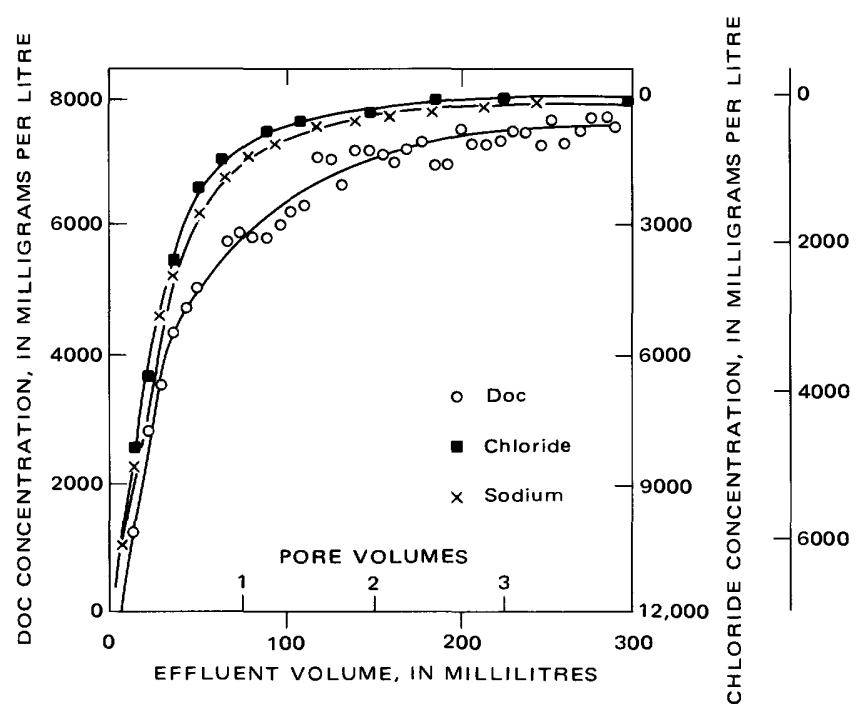

FIGURE 27.-Sodium, chloride, and DOC breakthrough curves for experiment 1 (flow rate $=2 \mathrm{ml} / \mathrm{hr}$ ). tions in the reacted waste during Experiments 1 and 2 are shown in tables 11 and 12 . The background concentration of $\mathrm{Fe}$ within the unreacted waste was 6 $\mathrm{mg} / \mathrm{l}$. While standing in the stainless steel lines and hydraulic separator, the waste very slowly solubilized Fe from these components of the pressurization coretesting apparatus. This rate was determined to be 0.02

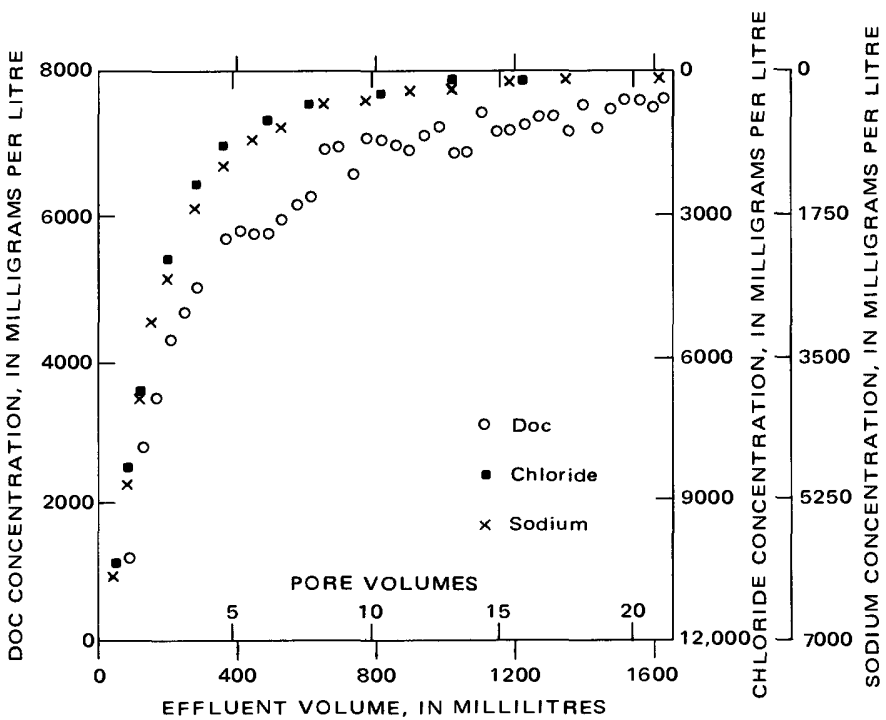

FigURE 28.-Sodium, chloride, and DOC breakthrough curves for experiment 2 (flow rate $=4 \mathrm{ml} / \mathrm{hr}$ ). 
TABLE 12. - Laboratory chemical data for waste-aquifer reactivity, experiment 2 (flow rate $=4 \mathrm{mllhr}$ )

\begin{tabular}{|c|c|c|c|c|c|c|c|c|c|c|c|c|}
\hline \multirow{2}{*}{$\begin{array}{c}\text { Time } \\
(\mathrm{hr})\end{array}$} & \multirow{2}{*}{$\begin{array}{c}\text { Fraction } \\
\text { number }\end{array}$} & \multirow{2}{*}{$\begin{array}{c}\text { Cumulative } \\
\text { volume } \\
(\mathrm{ml})\end{array}$} & \multirow{2}{*}{$\begin{array}{c}\text { Specific } \\
\text { conductance } \\
(\mu \text { mhos/cm } \\
\left.\text { at 25 } / 5^{\circ} \mathrm{C}\right)\end{array}$} & \multirow[b]{2}{*}{$\mathrm{pH}$} & \multicolumn{8}{|c|}{ Concentration in $\mathbf{m g} /$} \\
\hline & & & & & DOC & $\mathrm{Fe}$ & $\mathrm{Si}$ & $\mathrm{Na}$ & $\mathrm{Ca}$ & $\mathbf{M g}$ & $\mathrm{SO}_{4}$ & Cl \\
\hline $\begin{array}{r}0 \\
5 \\
10 \\
15 \\
20\end{array}$ & $\begin{array}{l}1 \\
2 \\
3 \\
4 \\
5\end{array}$ & $\begin{array}{r}20 \\
40 \\
60 \\
80 \\
100\end{array}$ & $\begin{array}{l}27,800 \\
26,900 \\
22,500 \\
17,500 \\
16,100\end{array}$ & $\begin{array}{l}7.50 \\
6.30 \\
5.90 \\
5.60 \\
5.30\end{array}$ & $\begin{array}{r}1.5 \\
1270 \\
2820 \\
3510 \\
4320\end{array}$ & $\begin{array}{r}0.3 \\
0.3 \\
2.0 \\
9.5 \\
12\end{array}$ & $\begin{array}{l}11 \\
20 \\
32 \\
53 \\
56\end{array}$ & $\begin{array}{l}6100 \\
5000 \\
3900 \\
3000 \\
2500\end{array}$ & $\begin{array}{r}490 \\
1100 \\
1800 \\
2100 \\
2500\end{array}$ & $\begin{array}{l}250 \\
240 \\
210 \\
180 \\
170\end{array}$ & $\begin{array}{l}420 \\
400 \\
350 \\
330 \\
300\end{array}$ & $\begin{array}{r}10,200 \\
8,200 \\
6,600 \\
3,800\end{array}$ \\
\hline $\begin{array}{l}25 \\
30 \\
35 \\
40 \\
45\end{array}$ & $\begin{array}{r}6 \\
7 \\
8 \\
9 \\
10\end{array}$ & $\begin{array}{l}120 \\
140 \\
160 \\
180 \\
200\end{array}$ & $\begin{array}{l}15,300 \\
14,900 \\
13,730 \\
12,380 \\
11,000\end{array}$ & $\begin{array}{l}5.10 \\
5.00 \\
4.90 \\
4.85 \\
4.75\end{array}$ & $\begin{array}{l}4700 \\
\mathbf{5 0 5 0} \\
5050 \\
\mathbf{5 7 5 0} \\
\mathbf{5 8 5 0}\end{array}$ & $\begin{array}{l}16 \\
24 \\
37 \\
-\end{array}$ & $\begin{array}{l}59 \\
63 \\
64 \\
64\end{array}$ & $\begin{array}{r}16 \overline{0} \\
11 \overline{0} \\
-\end{array}$ & $\begin{array}{r}28 \overline{00} \\
28 \overline{00} \\
-\end{array}$ & $\begin{array}{l}\frac{140}{120} \\
\frac{1}{-}\end{array}$ & $\begin{array}{r}290 \\
280 \\
220 \\
-\end{array}$ & $\begin{array}{r}2,2 \overline{200} \\
1,4 \overline{60} \\
-\end{array}$ \\
\hline $\begin{array}{l}50 \\
55 \\
60 \\
65 \\
70\end{array}$ & $\begin{array}{l}11 \\
12 \\
13 \\
14 \\
15\end{array}$ & $\begin{array}{l}220 \\
240 \\
260 \\
280 \\
300\end{array}$ & $\begin{array}{r}10,750 \\
10,500 \\
10,150 \\
10,250 \\
\mathbf{9 , 9 4 0}\end{array}$ & $\begin{array}{l}4.70 \\
4.65 \\
4.60 \\
4.55 \\
4.50\end{array}$ & $\begin{array}{l}5800 \\
5800 \\
6000 \\
6200 \\
6300\end{array}$ & $\frac{41}{48^{-}}$ & $\frac{\overline{65}}{\overline{68}}$. & $\begin{array}{r}780 \\
670 \\
-\end{array}$ & $\begin{array}{r}2800 \\
2800 \\
-\end{array}$ & $\begin{array}{r}110 \\
110 \\
-\end{array}$ & $\frac{160}{\frac{90}{20}}$ & $\begin{array}{l}8 \overline{8} \\
\overline{600}\end{array}$ \\
\hline $\begin{array}{l}75 \\
80 \\
85 \\
90 \\
95\end{array}$ & $\begin{array}{l}16 \\
17 \\
18 \\
19 \\
20\end{array}$ & $\begin{array}{l}320 \\
340 \\
360 \\
380 \\
400\end{array}$ & $\begin{array}{l}9,850 \\
9,690 \\
9,560 \\
9,170 \\
9,170\end{array}$ & $\begin{array}{l}4.48 \\
4.45 \\
4.40 \\
4.35 \\
4.35\end{array}$ & $\begin{array}{l}7000 \\
7000 \\
6600 \\
7150 \\
7100\end{array}$ & ${ }^{58^{-}}$ & $\frac{\frac{68}{70}}{\frac{68}{2}}$ & $\begin{array}{r}400 \\
\frac{-}{340} \\
-\end{array}$ & $\begin{array}{r}2600 \\
- \\
2600 \\
-\end{array}$ & $\frac{95}{-}$ & $\begin{array}{l}\bar{z} \\
\bar{z}\end{array}$ & $\begin{array}{l}\bar{Z} \\
\bar{z}\end{array}$ \\
\hline $\begin{array}{l}100 \\
105 \\
110 \\
115 \\
120\end{array}$ & $\begin{array}{l}21 \\
22 \\
23 \\
24 \\
25\end{array}$ & $\begin{array}{l}420 \\
440 \\
460 \\
480 \\
500\end{array}$ & $\begin{array}{l}9,050 \\
9,050 \\
8,290 \\
7,900 \\
8,040\end{array}$ & $\begin{array}{l}4.35 \\
4.35 \\
4.30 \\
4.30 \\
4.30\end{array}$ & $\begin{array}{l}7050 \\
6950 \\
7150 \\
7250 \\
6900\end{array}$ & $\begin{array}{l}70 \\
79 \\
80^{-}\end{array}$ & $\begin{array}{l}\frac{66}{65} \\
\frac{-}{65}\end{array}$ & $\begin{array}{l}2 \overline{30} \\
\overline{\overline{7}} \\
1 \overline{70}\end{array}$ & $\begin{array}{r}24 \overline{0} \\
\overline{-} \\
2400\end{array}$ & $\begin{array}{l}\overline{80} \\
\overline{78}\end{array}$ & $\begin{array}{l}\overline{<1} \\
\overline{-}\end{array}$ & $\begin{array}{l}\bar{Z} \\
\overline{180}\end{array}$ \\
\hline $\begin{array}{l}125 \\
130 \\
135 \\
140 \\
145\end{array}$ & $\begin{array}{l}26 \\
27 \\
28 \\
29 \\
30\end{array}$ & $\begin{array}{l}\mathbf{5 2 0} \\
\mathbf{5 4 0} \\
\mathbf{5 6 0} \\
\mathbf{5 8 0} \\
\mathbf{6 0 0}\end{array}$ & $\begin{array}{l}8,160 \\
7,000 \\
8,160 \\
7,720 \\
7,460\end{array}$ & $\begin{array}{l}4.25 \\
4.20 \\
4.15 \\
4.15 \\
4.15\end{array}$ & $\begin{array}{l}6900 \\
7450 \\
7200 \\
7200 \\
7300\end{array}$ & $\begin{array}{l}= \\
= \\
=\end{array}$ & $\frac{67}{\frac{72}{69}}$ & $\frac{-}{140}$ & $\begin{array}{r}\overline{-} \\
2400 \\
-\end{array}$ & $\frac{\overline{-}}{\overline{74}}$ & $\begin{array}{l}\bar{z} \\
\overline{<1}\end{array}$ & $\begin{array}{l}\bar{Z} \\
\overline{160}\end{array}$ \\
\hline $\begin{array}{l}150 \\
155 \\
160 \\
165 \\
170\end{array}$ & $\begin{array}{l}31 \\
32 \\
33 \\
34 \\
35\end{array}$ & $\begin{array}{l}620 \\
640 \\
660 \\
680 \\
700\end{array}$ & $\begin{array}{l}7,720 \\
7,720 \\
7,650 \\
7,710 \\
7,800\end{array}$ & $\begin{array}{l}4.20 \\
4.15 \\
4.15 \\
4.10 \\
4.10\end{array}$ & $\begin{array}{l}7400 \\
7400 \\
7200 \\
7550 \\
7200\end{array}$ & $\begin{array}{l}90 \\
95 \\
93\end{array}$ & $\frac{\overline{72}}{\overline{72}}$ & $\begin{array}{l}\overline{-} \\
\overline{120} \\
\overline{-}\end{array}$ & $\begin{array}{r}\overline{-} \\
2300 \\
=\end{array}$ & $\begin{array}{l}\overline{-} \\
\overline{70} \\
-\end{array}$ & $\begin{array}{l}\bar{z} \\
\bar{z}\end{array}$ & $\begin{array}{l}\bar{z} \\
\bar{z}\end{array}$ \\
\hline $\begin{array}{l}175 \\
180 \\
185 \\
190 \\
195\end{array}$ & $\begin{array}{l}36 \\
37 \\
38 \\
39 \\
40\end{array}$ & $\begin{array}{l}720 \\
740 \\
760 \\
780 \\
800\end{array}$ & $\begin{array}{l}8,040 \\
7,780 \\
7,630 \\
7,360 \\
7,600\end{array}$ & $\begin{array}{l}4.10 \\
4.10 \\
4.10 \\
4.10 \\
4.08\end{array}$ & $\begin{array}{l}7500 \\
7600 \\
7600 \\
7500 \\
7550\end{array}$ & $\begin{array}{c}96- \\
97^{-}\end{array}$ & $\frac{\frac{69}{71}}{\frac{60}{2}}$ & $\begin{array}{r}1 \overline{00} \\
-\quad-\end{array}$ & $\begin{array}{r}23 \overline{00} \\
--\end{array}$ & $\frac{\overline{66}}{-}$ & $\bar{z}$ & $\begin{array}{l}\bar{Z} \\
\overline{120}\end{array}$ \\
\hline $\begin{array}{l}200 \\
205 \\
210 \\
215 \\
220\end{array}$ & $\begin{array}{l}41 \\
42 \\
43 \\
44 \\
45\end{array}$ & $\begin{array}{l}820 \\
840 \\
860 \\
880 \\
900\end{array}$ & $\begin{array}{l}7,580 \\
7,400 \\
7,420 \\
7,160 \\
7,150\end{array}$ & $\begin{array}{l}4.05 \\
4.05 \\
4.00 \\
4.00 \\
4.00\end{array}$ & $\begin{array}{r}7350 \\
7400 \\
7400 \\
7600\end{array}$ & $\begin{array}{c}102 \\
96 \\
99^{-}\end{array}$ & $\begin{array}{l}\frac{69}{56} \\
-\end{array}$ & $\frac{88}{\overline{7}}$ & $\begin{array}{r}2200 \\
\overline{-} \\
2100\end{array}$ & $\frac{66}{\frac{-}{62}}$ & $\begin{array}{l}\bar{z} \\
\bar{z}\end{array}$ & $\begin{array}{l}\overline{-} \\
\bar{z}\end{array}$ \\
\hline $\begin{array}{l}225 \\
230 \\
235 \\
240 \\
245\end{array}$ & $\begin{array}{l}46 \\
47 \\
48 \\
49 \\
50\end{array}$ & $\begin{array}{r}920 \\
940 \\
960 \\
980 \\
1000\end{array}$ & $\begin{array}{l}7,120 \\
7,080 \\
6,810 \\
6,840 \\
6,910\end{array}$ & $\begin{array}{l}4.00 \\
4.00 \\
4.00 \\
4.00 \\
4.00\end{array}$ & $\begin{array}{l}\bar{z} \\
\overline{-}\end{array}$ & $\frac{99^{-}}{112^{-}}$ & $\frac{56}{54}$ & $\begin{array}{l}\bar{z} \\
\overline{75}\end{array}$ & $\begin{array}{l}\bar{z} \\
2000\end{array}$ & $\begin{array}{l}\overline{-} \\
\overline{59}\end{array}$ & $\begin{array}{l}\bar{z} \\
\overline{<1}\end{array}$ & $\begin{array}{l}\bar{Z} \\
\overline{100}\end{array}$ \\
\hline $\begin{array}{l}250 \\
255 \\
260 \\
265 \\
270\end{array}$ & $\begin{array}{l}\mathbf{5 1} \\
\mathbf{5 2} \\
\mathbf{5 3} \\
\mathbf{5 4} \\
\mathbf{5 5}\end{array}$ & $\begin{array}{l}1020 \\
1040 \\
1060 \\
1080 \\
1100\end{array}$ & $\begin{array}{l}6,920 \\
7,000 \\
6,740 \\
5,150 \\
6,740\end{array}$ & $\begin{array}{l}4.00 \\
4.00 \\
4.00 \\
3.95 \\
3.95\end{array}$ & $\begin{array}{c}7700 \\
\underset{\text { Samp }}{7800}\end{array}$ & $\begin{array}{c}113- \\
108 \\
\text { sacrifice } \\
-\end{array}$ & $\frac{\overline{57}}{\operatorname{gas} a}$ & $\begin{array}{r}\text { - } \\
\text { alysis }\end{array}$ & $\begin{array}{l}- \\
-\end{array}$ & $\begin{array}{l}\overline{-} \\
-\end{array}$ & $\begin{array}{l}\overline{-} \\
-\end{array}$ & $\begin{array}{l}\overline{-} \\
-\end{array}$ \\
\hline $\begin{array}{l}275 \\
280 \\
285 \\
290 \\
295\end{array}$ & $\begin{array}{l}56 \\
57 \\
58 \\
59 \\
60\end{array}$ & $\begin{array}{l}1120 \\
1140 \\
1160 \\
1180 \\
1200\end{array}$ & $\begin{array}{l}6,760 \\
6,630 \\
6,370 \\
6,440 \\
6,310\end{array}$ & $\begin{array}{l}3.95 \\
3.95 \\
3.90 \\
3.90 \\
3.90\end{array}$ & $\frac{\bar{z}}{\bar{z}}$ & $\begin{array}{l}109 \\
108 \\
110^{-}\end{array}$ & $\frac{\overline{58}}{54}$ & $\frac{\bar{z}}{38}$ & $\begin{array}{r}\overline{-} \\
1900 \\
-\end{array}$ & $\bar{z}$ & $\begin{array}{l}\overline{-} \\
\overline{<1}\end{array}$ & $\begin{array}{l}\bar{z} \\
\bar{z}\end{array}$ \\
\hline $\begin{array}{l}300 \\
305 \\
310 \\
315 \\
320\end{array}$ & $\begin{array}{l}61 \\
62 \\
63 \\
64 \\
65\end{array}$ & $\begin{array}{l}1220 \\
1240 \\
1260 \\
1280 \\
1300\end{array}$ & $\begin{array}{l}\mathbf{6}, 120 \\
\mathbf{5 , 9 9 0} \\
\mathbf{5 , 9 4 0} \\
\mathbf{6 , 1 9 0} \\
\mathbf{5 , 9 9 0}\end{array}$ & $\begin{array}{l}3.90 \\
3.90 \\
3.90 \\
3.90 \\
3.90\end{array}$ & $\begin{array}{l}\overline{-} \\
7850 \\
-\end{array}$ & ${ }_{115^{-}}^{-}$ & $\frac{56}{\frac{54}{55}}$ & $\begin{array}{l}\bar{z} \\
\overline{-}\end{array}$ & $\begin{array}{l}\bar{z} \\
\bar{z}\end{array}$ & $\begin{array}{l}\overline{-} \\
\overline{-}\end{array}$ & $\begin{array}{l}\bar{z} \\
\bar{z}\end{array}$ & $\begin{array}{l}\overline{-} \\
\overline{-}\end{array}$ \\
\hline
\end{tabular}


TABLE 12. - Laboratory chemical data for waste-aquifer reactivity, experiment 2 (flow rate $=4 \mathrm{ml} / \mathrm{hr}$ ) - Continued

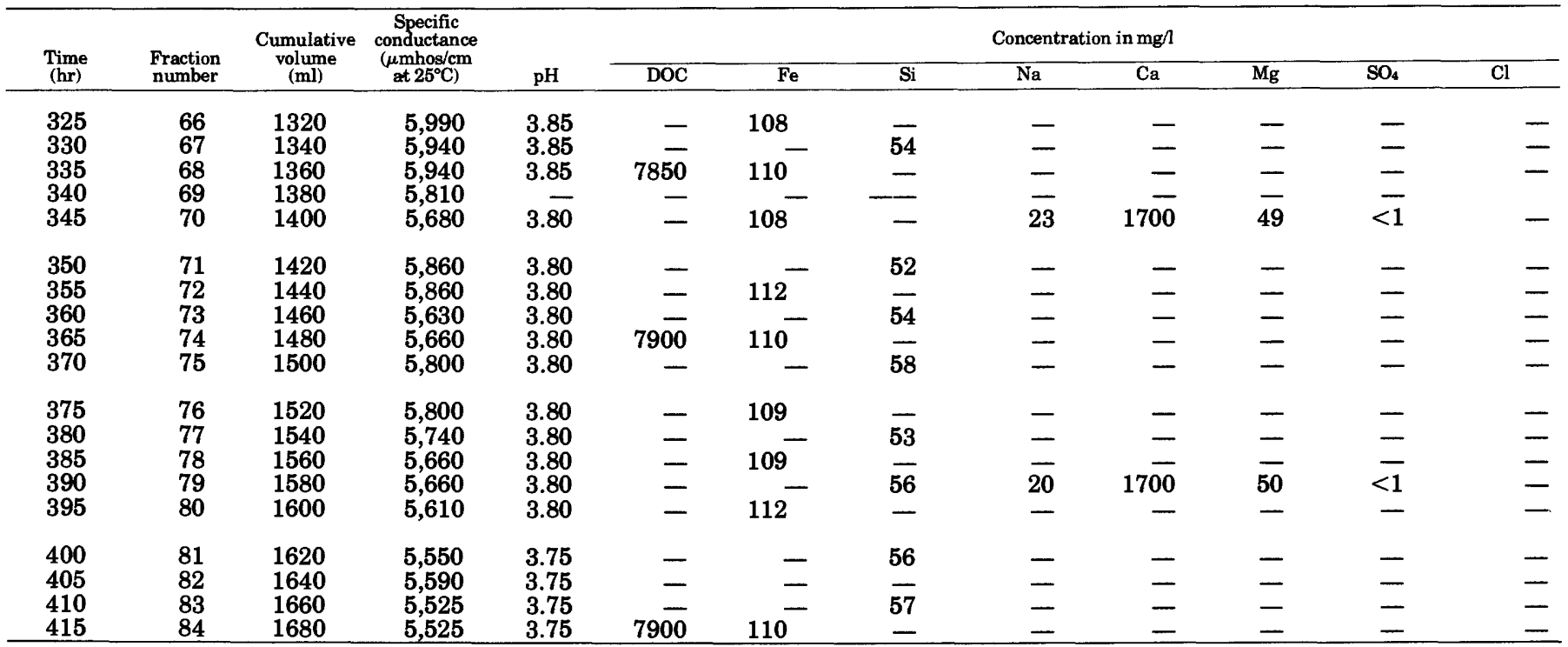

$\mathrm{mg} / \mathrm{l} / \mathrm{day}$ in three independent measurements during experiments 1 and 2 . The reported values of $\mathrm{Fe}$ are corrected for background and solubilization within the apparatus. This small concentration of background $\mathrm{Fe}$ concentration should have no effect upon the rate of $\mathrm{Fe}$ solubilization from aquifer material. The high background concentration of $\mathrm{Si}$ in the injected waste probably had an effect upon $\mathrm{Si}$ dissolution of aquifer material. The high initial $\mathrm{Si}$ concentration probably decreased the rate of $\mathrm{Si}$ dissolution and probably decreased the total amount of Si dissolution because the high background enabled pseudo-equilibrium concentrations of Si to be attained more quickly than if no $\mathrm{Si}$ were present in the initial waste.

Specific conductance and $\mathrm{pH}$ are gross chemical indicators which are affected by a number of interdepen-

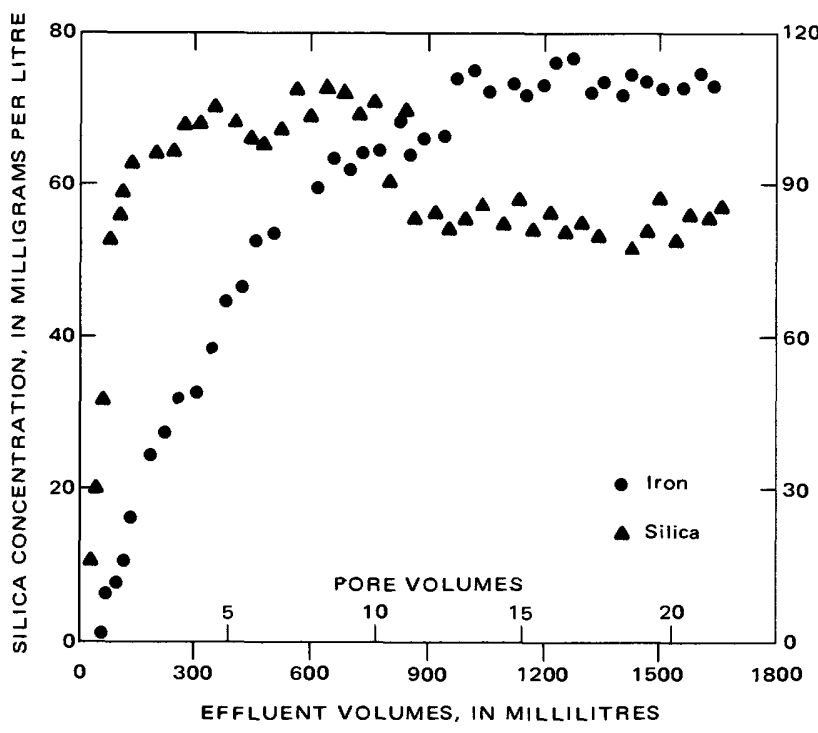

FIGURE 29.-Iron and silica dissolution during experiment 2. dent chemical parameters. Therefore, $\mathrm{pH}$ and specific conductance are of limited usefulness except as general continuous monitoring indicators.

The initial appearance of gas at the outlet of the core holder at fraction 11 during experiment 1 was accompanied with a large drop in $\mathrm{pH}$ from 6.80 to 6.20 and an abrupt appearance of dissolved Fe. The initial appearance of gas during experiment 2 occurred in fraction 3 accompanied by incipient Fe dissolution. The $\mathrm{pH}$ was lower at $\mathrm{pH} 5.9$ due to the rapid flush of unreacted waste acids. Although all the $\mathrm{CO}_{2}$ gas produced during carbonate dissolution within the core was believed to have remained in solution while within the core, outgassing of $\mathrm{CO}_{2}$ during sampling was an immediate

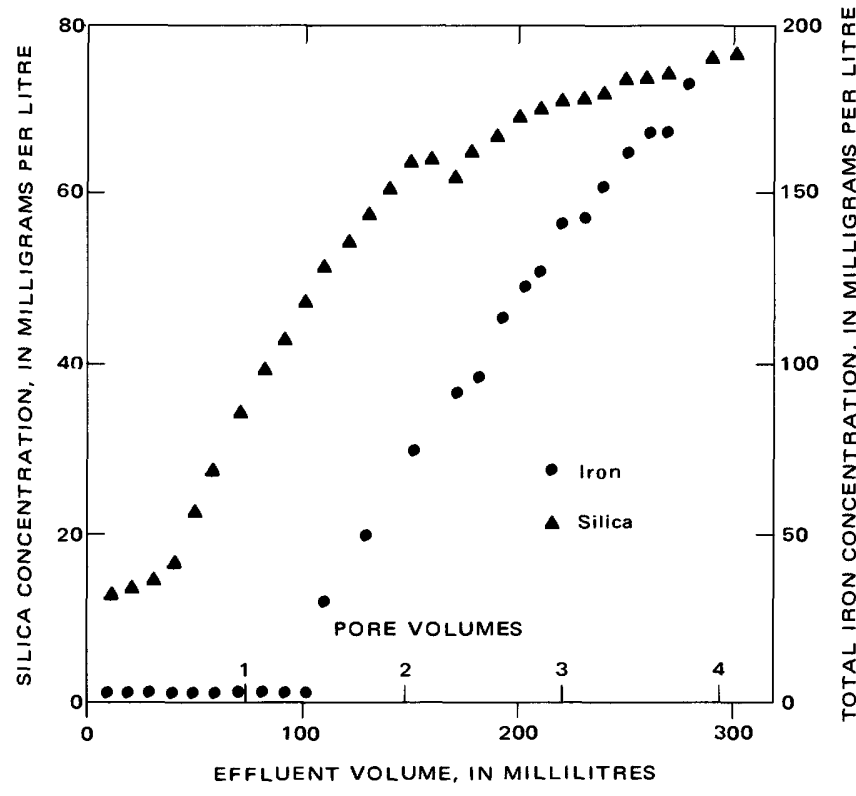

FIGURE 30.-Iron and silica dissolution during experiment 1. 
manifestation of carbonate dissolution. The marked increase in $\mathrm{Ca}$ content of the waste effluent as high as $4,300 \mathrm{mg} / \mathrm{l}$ during experiment 1 was an accurate indicator of carbonate dissolution. Gas effervescence during sample collection at the end of experiment 1 and at fraction 20 of experiment 2 , occupied over 50 percent by volume of the collection tube.

During experiment 2, gas effervescence declined with $\mathrm{Ca}$ concentration. Only small amounts of gas remained at fraction 50, and gas was essentially absent after fraction 75 . Ca concentrations did not approach zero during experiment 2 becaue the concentration of the injected waste was $1,400 \mathrm{mg} / \mathrm{l}$.

The carbonate in the injection zone was probably low in dolomite because the $\mathrm{Mg}$ concentration constantly decreased at the expense of $\mathrm{Ca}$. Magnesium and sodium, which were competitive with $\mathrm{Ca}$ for the exchange sites on the native aquifer material, were gradually leached from the core with $\mathrm{Ca}$ and hydrogen becoming the dominant exchange ions.

\section{EXPERIMENT 2 - CORE SOLUBILIZATION STUDY}

Experiment 2 was designed to simulate changes which would be manifested within the aquifer material with the passage of the waste front extending into the slow-reaction zone. Sampling of the waste effluent during this experiment as shown in tables 13 and 14 was conducted at 5-hour intervals over an 18-day period at an average flow rate of $4 \mathrm{ml} / \mathrm{hr}$. At the termination of experiment 2, the waste in the pore space within the core was displaced by passing $180 \mathrm{ml}$ of native ground water through the core. At this volume, the specific conductance of the effluent was constant at the specific conductance of the native ground water. The core holder was then disassembled, the aquifer core material extruded from the Teflon sleeve, and the core fractionated into eight equal sections of 1.5 inches $(38 \mathrm{~mm})$. Sections 1 through 8 were numbered from the top (waste entry end) of the column.

The lag in the DOC breakthrough curve behind chloride during experiments 1 and 2 as shown in figures 26 and 27 indicates that organic components are being sorbed onto the aquifer material throughout the entire duration of both experiments. In addition to DOC, six specific organic compounds (formaldehyde, acetic acid, formic acid, phthalic acid, terephthalic acid, and $p$-toluic acid) were monitored. These compounds collectively comprised over 80 percent of the DOC in the waste. All of these compounds except formaldehyde were sorbed onto the aquifer core material.

The breakthrough curve and breakthrough data for formaldehyde during experiment 2 as shown in figure

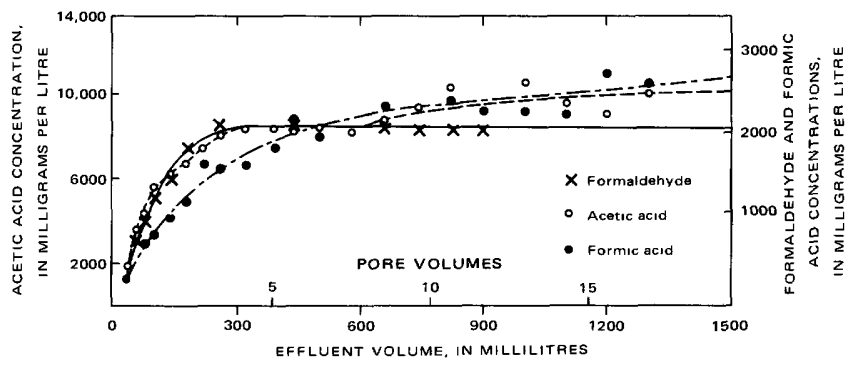

FIGURE 31.-Relative sorption of formaldehyde, acetic acid, and formic acid during experiment 2 .

TABLE 13.-Organic chemical data during waste effluent monitoring of laboratory experiment 2

\begin{tabular}{|c|c|c|c|c|c|c|c|c|c|c|c|}
\hline \multirow[b]{2}{*}{$\underset{(\mathrm{hr})}{\text { Time }}$} & \multirow[b]{2}{*}{$\begin{array}{c}\text { Fraction } \\
\text { number }\end{array}$} & \multirow[b]{2}{*}{$\begin{array}{c}\text { Cumulative } \\
\text { volume }\end{array}$} & \multicolumn{4}{|c|}{ Concentration $(\mathrm{mg} / \mathrm{l})$} & \multirow{2}{*}{$\begin{array}{l}\text { Acetic/formic } \\
\text { acid } \\
\text { ratio }\end{array}$} & \multicolumn{3}{|c|}{ Concentration (mg/) } & \multirow{2}{*}{$\begin{array}{l}\text { Phthalic: } \\
\text { terephthalic: } \\
\text { p-toluic ratio }\end{array}$} \\
\hline & & & $\mathrm{DOC}$ & Formaldehyde & $\begin{array}{c}\text { Formic } \\
\text { acid }\end{array}$ & $\begin{array}{c}\text { Acetic } \\
\text { acid }\end{array}$ & & $\begin{array}{c}\text { Phthalic } \\
\text { acid }\end{array}$ & $\begin{array}{c}\text { Terephthalic } \\
\text { acid }\end{array}$ & $\begin{array}{l}p \text {-Toluic } \\
\text { acid }\end{array}$ & \\
\hline $\begin{array}{r}0 \\
5 \\
10 \\
15 \\
20\end{array}$ & $\begin{array}{l}1 \\
2 \\
3 \\
4 \\
5\end{array}$ & $\begin{array}{r}20 \\
40 \\
60 \\
80 \\
100\end{array}$ & $\begin{array}{r}1.5 \\
1270 \\
2820 \\
3510 \\
4320\end{array}$ & $\begin{array}{r}0 \\
370 \\
745 \\
925 \\
1200\end{array}$ & $\begin{array}{l}\overline{340} \\
780 \\
735 \\
863\end{array}$ & $\begin{array}{l}19 \overline{-} \\
3620 \\
4410 \\
5840\end{array}$ & $\begin{array}{l}5.8 \\
4.6 \\
5.9 \\
6.7\end{array}$ & $\begin{array}{r}\overline{36} \\
45 \\
95 \\
119\end{array}$ & $\begin{array}{r}-56 \\
75 \\
145 \\
162\end{array}$ & $\begin{array}{r}\overline{58} \\
103 \\
188 \\
204\end{array}$ & $\begin{array}{l}1: 1.5: 1.6 \\
1: 1.6: 2.3 \\
1: 1.5: 1.8 \\
1: 1.4: 1.7\end{array}$ \\
\hline $\begin{array}{l}30 \\
40 \\
50 \\
60 \\
75\end{array}$ & $\begin{array}{r}7 \\
9 \\
11 \\
13 \\
16\end{array}$ & $\begin{array}{l}140 \\
180 \\
220 \\
260 \\
320\end{array}$ & $\begin{array}{l}5050 \\
5750 \\
5800 \\
6000 \\
7000\end{array}$ & $\begin{array}{l}1520 \\
1840 \\
1840 \\
2080 \\
2120\end{array}$ & $\begin{array}{l}1050 \\
1210 \\
1710 \\
1660 \\
1700\end{array}$ & $\begin{array}{l}6510 \\
6870 \\
7620 \\
8140 \\
8610\end{array}$ & $\begin{array}{l}6.2 \\
5.6 \\
4.4 \\
4.9 \\
5.1\end{array}$ & $\begin{array}{l}179 \\
191 \\
160 \\
180 \\
177\end{array}$ & $\begin{array}{l}209 \\
295 \\
280 \\
302 \\
364\end{array}$ & $\begin{array}{l}226 \\
399 \\
407 \\
435 \\
606\end{array}$ & $\begin{array}{l}1: 1.2: 1.3 \\
1: 1.5: 2.1 \\
1: 1.8: 2.6 \\
1: 1.7: 2.4 \\
1: 2.0: 3.4\end{array}$ \\
\hline $\begin{array}{r}90 \\
105 \\
120 \\
140 \\
160\end{array}$ & $\begin{array}{l}19 \\
22 \\
25 \\
29 \\
33\end{array}$ & $\begin{array}{l}380 \\
440 \\
500 \\
580 \\
660\end{array}$ & $\begin{array}{l}7150 \\
6950 \\
6900 \\
7200 \\
7200\end{array}$ & $\begin{array}{l}2100 \\
2150 \\
2100 \\
2050 \\
2120\end{array}$ & $\begin{array}{l}1890 \\
2170 \\
2030 \\
2110 \\
2410\end{array}$ & $\begin{array}{l}8440 \\
8290 \\
8660 \\
8190 \\
8890\end{array}$ & $\begin{array}{l}4.8 \\
3.8 \\
4.2 \\
3.9 \\
3.7\end{array}$ & $\begin{array}{l}152 \\
153 \\
157 \\
184 \\
190\end{array}$ & $\begin{array}{l}357 \\
343 \\
348 \\
303 \\
453\end{array}$ & $\begin{array}{l}563 \\
571 \\
557 \\
524 \\
803\end{array}$ & $\begin{array}{l}1: 2.3: 3.7 \\
1: 2.2: 3.7 \\
1: 2.2: 3.5 \\
1: 1.6: 2.8 \\
1: 2.4: 4.2\end{array}$ \\
\hline $\begin{array}{l}180 \\
200 \\
220 \\
245 \\
270\end{array}$ & $\begin{array}{l}37 \\
41 \\
45 \\
50 \\
55\end{array}$ & $\begin{array}{r}740 \\
820 \\
900 \\
1000 \\
1100\end{array}$ & $\begin{array}{l}7600 \\
7350 \\
7600 \\
7675 \\
7750\end{array}$ & $\begin{array}{r}2100 \\
2020 \\
2080 \\
- \\
-\end{array}$ & $\begin{array}{l}2110 \\
2470 \\
2280 \\
2320 \\
2280\end{array}$ & $\begin{array}{r}9480 \\
10,500 \\
9130 \\
10,700 \\
9690\end{array}$ & $\begin{array}{l}4.5 \\
4.2 \\
4.0 \\
4.6 \\
4.2\end{array}$ & $\begin{array}{l}157 \\
171 \\
140 \\
134 \\
225\end{array}$ & $\begin{array}{l}334 \\
315 \\
356 \\
355 \\
289\end{array}$ & $\begin{array}{l}551 \\
539 \\
639 \\
618 \\
392\end{array}$ & $\begin{array}{l}1: 2.2: 3.5 \\
1: 1.9: 3.1 \\
1: 2.5: 4.5 \\
1: 2.7: 4.6 \\
1: 1.3: 1.8\end{array}$ \\
\hline $\begin{array}{c}295 \\
320 \\
\text { Waste } \\
\text { analysis }\end{array}$ & $\begin{array}{l}60 \\
65\end{array}$ & $\begin{array}{l}1200 \\
1300\end{array}$ & $\begin{array}{l}7850 \\
7850 \\
7900\end{array}$ & 2100 & $\begin{array}{l}2800 \\
2640 \\
\\
2780\end{array}$ & $\begin{array}{r}9160 \\
10,200\end{array}$ & $\begin{array}{l}3.2 \\
3.8\end{array}$ & $\begin{array}{l}226 \\
168\end{array}$ & $\begin{array}{l}352 \\
330\end{array}$ & $\begin{array}{l}512 \\
517\end{array}$ & $\begin{array}{l}1: 1.5: 2.3 \\
1: 1.9: 3.1\end{array}$ \\
\hline
\end{tabular}


31 and table 13, respectively, indicate that formaldehyde is not sorbed because its breakthrough curve is essentially the same as for chloride. After fraction 16 , the formaldehyde concentration is constant at 2,100 $\mathrm{mg} / \mathrm{l}$, which is the formaldehyde concentration of the injected waste. This finding suggests that formaldehyde may be used as an organic tracer under similar chemical conditions as existed in this experiment and that the degree of sorption of all other organic constituents can be measured as a difference between their concentration in the reacted effluent waste and that of the original injected waste.

Formic acid was the most strongly sorbed organic compound on a percent by weight basis as shown in figure 31 and table 13. Formic acid was sorbed during most of the experiment with the exception of the very latter stages. At fraction 16, the formic acid concentration was only 60 percent of its concentration in the injected waste. Formic acid sorption was marked not only at the initial portion of the experiment, but was also considerable during the middle to latter portion of the experiment after considerable $\mathrm{Fe}$ and $\mathrm{SiO}_{2}$ dissolution when the $\mathrm{pH}$ was between 4.10 and 4.00.

The formic acid molecule is quite liable or subject to chemical and (or) catalytic decomposition. It is possible that the apparent sorption of formic acid was not sorption, but decomposition of a portion of the formic acid. This possible chemical or catalytic decomposition could have occurred with the diverse components of the core material until the incompatible chemical core constituents were consumed or possible catalytic sites were exhausted or hindered by sorption of other organic constituents. A possible data interpretation is that formic acid concentration in the waste effluent gradually approached its concentration within the initial waste only after the possible chemical or catalytic activity ceased within the core.

Acetic acid was the second most strongly sorbed organic compound on a percent by weight basis. At fraction 16 , the acetic acid concentration was 84 percent of its concentration in the injected waste. Acetic acid is not initially strongly sorbed as its breakthrough curve parallels the non-sorbed formaldehyde component.
From fraction 8 through fraction 30 , acetic acid is strongly sorbed coincident with marked $\mathrm{Fe}$ and $\mathrm{SiO}_{2}$ solubilization. After fraction 30, acetic acid is less strongly sorbed and gradually attains the same concentration as in the injected waste.

The sorption of phthalic and terephthalic acids are only vaguely suggested during the initial waste monitoring portion of experiment 2 as shown in table 13. The sorption of $p$-toluic acid is indicated by the phthalic:terephthalic: $p$-toluic acid ratio inclusive of fraction 16 . The relative sorption of these three aromatic acids by waste effluent monitoring is dramatically manifested during the slow flow rate of experiment 1 . As shown in figure 32 and table 14, there is initial sorption of all three aromatic acids. The flow rate of experiment 2 was too rapid to obtain the necessary detail for aromatic acid sorption.

Phthalic acid is strongly sorbed only during the first $150-\mathrm{ml}$ of waste input. This sorption is suggested by

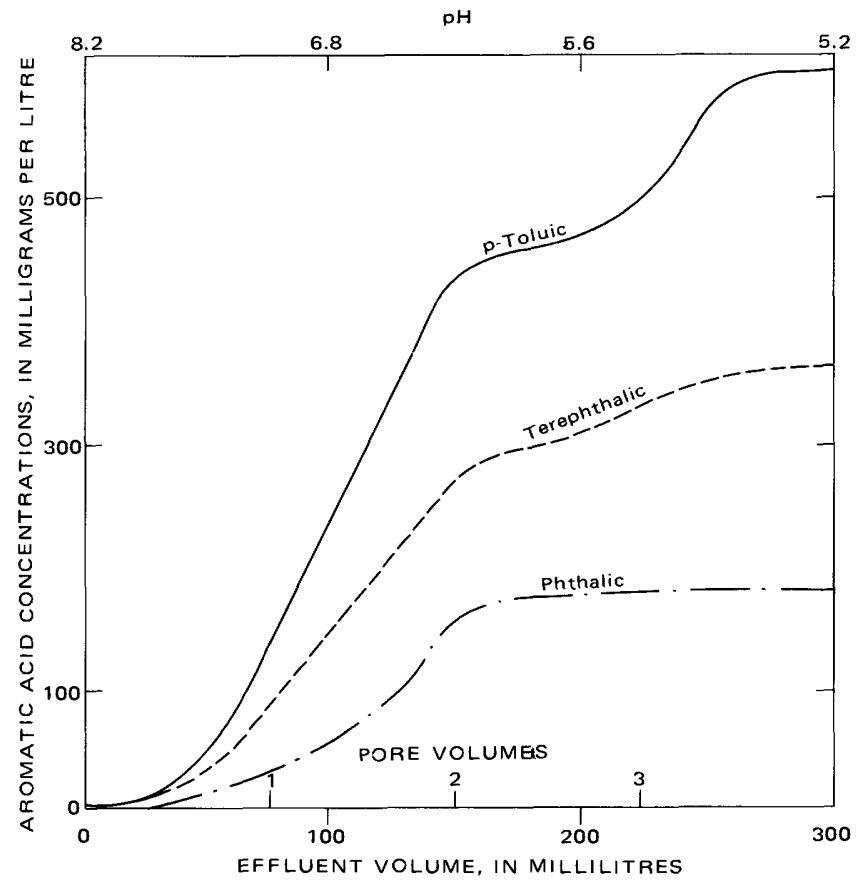

FIGURE 32.-Relative sorption of phthalic, terephthalic, and $p$-toluic acids during experiment 1.

TABLE 14. - Organic chemical data during waste effluent monitoring of laboratory experiment 1

\begin{tabular}{|c|c|c|c|c|c|c|c|c|c|c|}
\hline \multirow[b]{2}{*}{$\begin{array}{c}\text { Time } \\
\text { (hr) }\end{array}$} & \multirow[b]{2}{*}{$\begin{array}{l}\text { Fraction } \\
\text { number }\end{array}$} & \multirow[b]{2}{*}{$\begin{array}{c}\text { Cumulative } \\
\text { volume }\end{array}$} & \multicolumn{4}{|c|}{ Concentration in $\mathrm{mg} / \mathrm{l}$} & \multirow{2}{*}{$\begin{array}{l}\text { Phthalic: } \\
\text { terephthalic: } \\
p \text {-toluic ratio }\end{array}$} & \multicolumn{3}{|c|}{$\begin{array}{l}\text { Percent of fraction DOC accounted } \\
\text { for by compound }\end{array}$} \\
\hline & & & DOC & $\begin{array}{c}\text { Phthalic } \\
\text { acid }\end{array}$ & $\begin{array}{c}\text { Terephthalic } \\
\text { acid }\end{array}$ & $\begin{array}{c}p \text {-Toluic } \\
\text { acid }\end{array}$ & & $\begin{array}{c}\text { Phthalic } \\
\text { acid }\end{array}$ & $\begin{array}{c}\text { Terephthalic } \\
\text { acid }\end{array}$ & $\begin{array}{c}p \text {-Toluic } \\
\text { acid }\end{array}$ \\
\hline $\begin{array}{c}30 \\
40 \\
55 \\
70 \\
90 \\
105 \\
125 \\
140 \\
\text { Waste } \\
\text { analysis. }\end{array}$ & $\begin{array}{r}7 \\
9 \\
12 \\
15 \\
19 \\
22 \\
26 \\
29\end{array}$ & $\begin{array}{r}70 \\
90 \\
120 \\
150 \\
190 \\
220 \\
260 \\
290\end{array}$ & $\begin{array}{l}2500 \\
4100 \\
5600 \\
6500 \\
7100 \\
7100 \\
7600 \\
7700 \\
7900\end{array}$ & $\begin{array}{r}24 \\
42 \\
65 \\
150 \\
160 \\
217 \\
142 \\
164 \\
169\end{array}$ & $\begin{array}{r}81 \\
113 \\
186 \\
273 \\
390 \\
324 \\
350 \\
338 \\
358\end{array}$ & $\begin{array}{l}124 \\
193 \\
304 \\
428 \\
450 \\
481 \\
600 \\
591 \\
596\end{array}$ & $\begin{array}{l}\text { 1:3.2:5.0 } \\
1: 2.7: 4.6 \\
1: 2.8: 4.6 \\
1: 1.8: 2.9 \\
1: 1.8: 2.8 \\
1: 1.5: 2.2 \\
1: 2.4: 4.2 \\
1: 2.1: 3.6 \\
1: 2.1: 3.5\end{array}$ & $\begin{array}{l}0.010 \\
.010 \\
.012 \\
.023 \\
.021 \\
.030 \\
.018 \\
.021 \\
.021\end{array}$ & $\begin{array}{r}0.032 \\
.028 \\
.033 \\
.042 \\
.030 \\
.045 \\
.046 \\
.044 \\
.045\end{array}$ & $\begin{array}{r}0.050 \\
.047 \\
.054 \\
.065 \\
.048 \\
.068 \\
.078 \\
.076 \\
.075\end{array}$ \\
\hline
\end{tabular}


the aromatic acid ratio in table 14 and confirmed by the percentage of fraction DOC accounted by phthalic acid. Aproximately 50 percent of the phthalic acid in the waste effluent had been sorbed.

Terephthalic acid is sorbed during the first $220-\mathrm{ml}$ of waste input. The most marked sorption occurs after phthalic acid sorption as indicated by the plateau in the breakthrough curve between 150 and $250 \mathrm{ml}$ in figure 31 , by the low aromatic acid ratio in this region of the breakthrough curve, and by the percentage of fraction DOC accounted by terephthalic acid in table 4 . Approximately 30 percent of the terephthalic acid in the effluent waste through fraction 22 was sorbed onto the aquifer material.

The sorption of $p$-toluic acid during the initial portion of experiment 2 is strongly supported by the $p$-toluic acid breakthrough curve during experiment 1 as shown in figure 32 and table 14. $p$-Toluic acid is sorbed in the same region of the breakthrough curve as terephthalic acid with continued sorption in the 220- to $260-\mathrm{ml}$ region. Strong sorption of $p$-toluic acid is indicated by the plateau in the 150 - to $250-\mathrm{ml}$ region of the breakthrough curve, by the low aromatic acid ratios in this region, and by the percentage of fraction DOC accounted by $p$-toluic acid. Approximately 30 percent of the $p$-toluic acid in the effluent waste was sorbed onto the aquifer material up through fraction 26.

The sorption of phthalic, terephthalic, and $p$-toluic acids were also confirmed by sediment extraction at the termination of experiment 2 . The sorptive capacities as determined on four sections of the reacted core are listed in table 15. Exclusive of section 1, the sorptive capacities are in a ratio of 1.0:5.5:4.7. This ratio as compared to the ratio of these compounds in the injected waste (1.0:2.1:3.5), indicate a sorptive preference for terephthalic and phthalic acids with the greatest preference for terephthalic acid.

TABLE 15.-Sorptive capacities of aromatic organic acids on aquifer material during experiment 2

\begin{tabular}{ccccc}
\hline & \multicolumn{3}{c}{ Milligrams of acid sorbed per gram of sediment } \\
$\begin{array}{c}\text { Core section } \\
\text { number }\end{array}$ & Phthalic & Terephthalic & $p$-Toluic & $\begin{array}{c}\text { Phthalic: } \\
\text { terephthalic: } \\
p \text {-toluic ratio }\end{array}$ \\
\cline { 2 - 5 } 1 & 0.011 & 0.090 & 0.0059 & $1: 9: 0.6$ \\
3 & .025 & .117 & .116 & $1: 4.7: 4.6$ \\
6 & .020 & .106 & .106 & $1: 5.3: 5.3$ \\
8 & .019 & .127 & .081 & $1: 6.6: 4.3$ \\
\hline
\end{tabular}

The sorptive capacities as shown in table 15 should be considered as minimal sorptive capacities because some portion of the organic acids were desorbed during the saturation of the aquifer core material with native saline water at the end of the experiment. This exchange or desorption of organic compounds is assured by mass action theory and supported by the extremely low sorptive capacities in section 1 at the input end of the column which was in contact with the saline water for the longest time period. The conclusion is limited by the fact that the clay fraction which would be expected to sorb most of the organic substances was somewhat depleted from section 1.

The overwhelming concentration of these compounds in the waste saturating the interstitial pore liquid would have precluded the analysis of sorbed material without flushing with native ground water. The ratio of the sorptive capacities suggests some limited validity of the sorptive capacities as determined because the ratio of the sorbed acids is markedly different from that of the injected waste. The relative meaning of the sorptive capacities will be discussed in detail after the presentation of supporting data obtained during experiment 3.

Carbonate dissolution was evident during experiment 2 by the high levels of $\mathrm{Ca}$ in the waste effluent (table 12) and by $\mathrm{CO}_{2}$ gas effervescence during waste effluent collection. Gas first appeared at fraction 3 and was present until fraction 75. Carbon dioxide gas persisted in the waste effluent much longer than expected for the low carbonate percentage of the aquifer material (table 16, 0.98 percent $\mathrm{CaCO}_{3}=0.12$ percent inorganic carbon) and the high organic acid concentration of the injected waste.

TABLE 16.-Organic and inorganic carbon analyses of fractionated and unfractionated injection-zone aquifer material

\begin{tabular}{|c|c|c|c|}
\hline & $\underset{\text { (percent) }}{\mathbf{O C}}$ & $\begin{array}{c}\text { IC }^{1} \\
\text { (percent) }\end{array}$ & $\begin{array}{c}\mathrm{CaCO}_{3}{ }^{1} \\
\text { (percent) }\end{array}$ \\
\hline $\begin{array}{l}\text { Whole aquifer material, ground................. } \\
\text { Clay fraction (<2microns).................... } \\
\text { Silt fraction }(2-64 \text { microns), unground } \\
\text { Fine sand }(0.064-0.4 \mathrm{~mm}) \text {, ungro. }\end{array}$ & $\begin{array}{r}0.15 \\
1.40 \\
.52\end{array}$ & $\begin{array}{r}0.12 \\
.14 \\
.22 \\
.10\end{array}$ & $\begin{array}{r}0.98 \\
1.18 \\
1.82 \\
.84\end{array}$ \\
\hline $\begin{array}{l}\text { Medium sand }(0.4-1.0 \mathrm{~mm}) \text {, unground } \ldots \ldots . . \\
\text { Combined sand }(0.064-2 \mathrm{~mm}) \text {, unground.... } \\
\text { Combined sand }(0.064-2 \mathrm{~mm}) \text {, ground } . . . . . .\end{array}$ & .03 & $\begin{array}{l}.05 \\
.08 \\
.09\end{array}$ & $\begin{array}{l}.40 \\
.65 \\
.71\end{array}$ \\
\hline
\end{tabular}

1 Analysis by modified Van Slyke method.

Temperature, pressure, the concentration of weak acid solutions, and the distribution of carbonate within the aquifer material are obviously important considerations for carbonate dissolution. The addition of the injected waste solution, acid concentration of approximately 2 percent by weight, to a sample of finely ground (less than $60 \mathrm{mesh}$ ) aquifer material at room temperature produced no observable gas effervescence. Upon standing at room temperature for 24 hours, only $1 / 3$ of the carbonate was dissolved from the sample. The remainder of the carbonate in the sample was converted to $\mathrm{CO}_{2}$ gas upon boiling for a period of $10 \mathrm{~min}-$ utes. On the other hand, addition of 3 percent $\mathrm{HCl}$, a strong acid, at room temperature produced strong gas effervescence. Upon standing for 3 hours over 90 percent of the carbonate was converted to $\mathrm{CO}_{2}$ gas.

A large portion of the carbonate in the aquifer material is secondary cementation carbonate because no detrital carbonates and few carbonaceous shells are 
observed with either the binocular microscope or thinsection analysis. Approximately 15-20 percent of the carbonate in the aquifer material is contained within the primary mineral sand grains which comprise over 75 percent of the aquifer material (table 17). As shown in table 16, the carbonate percentage for the unground combined sand fraction is approximately 10 percent less than the ground combined sand fraction. This carbonate would only be available to react with the acid waste by slow diffusion processes and with breakdown of the mineral grains.

TABLE 17.-Particle size analysis of injection-zone aquifer material

\begin{tabular}{|c|c|}
\hline & Percentage by weight \\
\hline Gravel $(>2 \mathrm{~mm})$ & 1 \\
\hline Coarse Sand $(1-2 \mathrm{~mm})$ & 4 \\
\hline Medium Sand $(0.4-1.0 \mathrm{~mm}) \ldots$ & 28 \\
\hline Fine Sand $(0.064-0.4 \mathrm{~mm})$ & 43 \\
\hline Silt (2-64 microns) & 20 \\
\hline Clay ( $<2$ microns) & 4 \\
\hline
\end{tabular}

With the previously discussed supporting experimental evidence, it is readily understood why carbonate dissolution was slow during experiment 2 . The experiment was conducted at room temperature, not elevated temperatures, carbonate dissolution was slow in the presence of the weak acid composition of the waste, and a portion of the carbonates were contained as primary mineral grains within sand grains. The 500 psi experimental pressure may have a positive effect upon carbonate dissolution because the $\mathrm{CO}_{2}$ gas produced would remain in solution at that pressure which would increase the carbonic acid or hydrogen ion concentration of aquifer fluids.

Carbonate analyses of the core sections at the termination of experiment 2 indicated that only a trace amount of carbonate was present in the aquifer core material. This trace carbonate level (less than 2 percent of the total carbonate percentage) represented the carbonate within the center portion of undecomposed sand grains.

With passage of the waste through the aquifer material, the $\mathrm{pH}$ of the core decreased from 8.2 to 3.73 , the $\mathrm{pH}$ of the injected waste. The cation exchange complex was changed from a mixed population of $\mathrm{Ca}, \mathrm{Mg}$, and $\mathrm{Na}$ to a predominantly $\mathrm{Ca}-\mathrm{H}$ system at the end of the experiment.

It was hoped that the marked dissolution of $\mathrm{SiO}_{2}$ and Fe during experiment 2 would be manifested in the analyses of the core material at the end of the experiment. The core material was the same reddish-brown color both at the beginning and the end of the experiment. Waste effluent analysis indicated that only 12 percent of the total extractable iron ( 0.4 percent of the sample weight) was removed during the experiment. The redistribution of the clay fraction within the core and the low amount of $\mathrm{Fe}$ solubilized during the exper- iment precluded $\mathrm{Fe}$ analyses of the core material. The iron which was dissolved from the core material was believed to have been amorphous sesquioxide coatings. This conclusion is supported by the associated Mn analyses in table 18 , because $\mathrm{Mn}, \mathrm{Fe}$, and $\mathrm{Al}$ sesquioxides are common coatings of aquifer grains.

TABLE 18. $-F e, A l$, and $M n$ analyses by graphite furnace technique of selected waste effluent fractions during experiment 2

\begin{tabular}{|c|c|c|c|c|}
\hline \multirow{2}{*}{$\begin{array}{l}\text { Sample } \\
\text { Designation }\end{array}$} & & \multicolumn{3}{|c|}{ Concentration in $\mathrm{mg} / \mathrm{l}$} \\
\hline & & $\mathrm{Fe}$ & $\mathrm{Al}$ & Mn \\
\hline \multicolumn{2}{|c|}{$\begin{array}{l}\text { Native ground water } \\
\text { Injected waste }\end{array}$} & $\begin{array}{l}<.2 \\
6.3\end{array}$ & $\begin{array}{l}<.7 \\
6.2\end{array}$ & $\begin{array}{c}0.17 \\
.5\end{array}$ \\
\hline Fraction & $\begin{array}{l}40 \\
50 \\
60\end{array}$ & $\begin{array}{r}116 \\
77 \\
116 \\
182 \\
\end{array}$ & $\begin{array}{l}8.7 \\
5.0 \\
8.7 \\
9.7\end{array}$ & $\begin{array}{l}6.7 \\
3.6 \\
4.7 \\
4.5\end{array}$ \\
\hline
\end{tabular}

The small amount of $\mathrm{SiO}_{2}$ dissolved during the experiment as compared to the overwhelming amount comprising primary and secondary minerals certainly precluded computation of $\mathrm{SiO}_{2}$ losses by core analysis. The high values for dissolved silica could result from dissolution of amorphous and crystalline clay minerals. The solubilization of Al-containing clay minerals is supported by the high $\mathrm{Al}$ values for fractions 40,50 , 60 , and 90 as shown in table 18.

The clay mineralogy of the original aquifer sample was approximately 25-40 percent 2:1-2:2 intergrade and mixed layered montmorillonite-intergrade, 25-35 percent montmorillonite, 5-10 percent illite, 5-10 percent amorphous clay minerals, and 2-4 percent quartz. $\mathrm{X}$-ray diffraction data at the termination of experiment 2 showed only a slight change in the stability of the 2:1-2:2 intergrade clay mineral. This suggested some removal of hydroxy $\mathrm{Al}$ and $\mathrm{Fe}$ polymers from interlayer space. A detailed discussion of the mineralogy of the waste-injection zone and mineralogical changes associated with waste injection is given by Malcolm, Leenheer, and Weed (1976).

EXPERIMENT 3 -WASTE-SATURATION STUDY

Experiment 3 was designed to simulate a unit of injected waste at the very edge of the waste front as it moved outward from the injection well. A 300-ml sample of waste was repeatedly reacted with fresh aquifer material until the waste was neutralized and "saturated" with dissolved aquifer constituents. The flow rate for the entire experiment was approximately 20 $\mathrm{ml} / \mathrm{hr}$. The waste was passed twice through each of the four consecutive cores. A 2-ml sample of the waste effluent was taken for specific conductance, $\mathrm{pH}, \mathrm{DOC}$, $\mathrm{SiO}_{2}$, and $\mathrm{Fe}$ analyses after each pass through the aquifer material. At the end of the experiment the waste effluent was analyzed for phthalic, terephthalic, and $p$-toluic acids.

The moisture content of the aquifer material was 11 percent by weight. This resulted in a 15 percent dilu- 
tion of the waste when introduced into each fresh core, and a total dilution of 60 percent for the entire experiment. This calculated dilution factor agrees well with the DOC experimental data (table 19), which indicates an actual dilution factor of 57 percent. Specific conductance cannot be used to calculate the dilution factor because conductance is increased with carbonate dissolution.

TABLE 19.-Chemical data during waste effluent monitoring of Laboratory experiment 3

\begin{tabular}{|c|c|c|c|c|c|c|c|}
\hline \multirow{2}{*}{$\begin{array}{l}\text { Sample } \\
\text { number }\end{array}$} & \multirow{2}{*}{$\begin{array}{c}\text { Laboratory } \\
\text { identification }\end{array}$} & \multirow{2}{*}{$\begin{array}{c}\text { Contact time } \\
\text { per pore } \\
\text { volume (hr) }\end{array}$} & \multirow{2}{*}{$\begin{array}{c}\text { Specific } \\
\text { conductance } \\
(\mu \mathrm{mho})\end{array}$} & \multirow[b]{2}{*}{ pH } & \multicolumn{3}{|c|}{ Concentration $(\mathrm{mg} / \mathrm{l})$} \\
\hline & & & & & DOC & $\mathrm{Fe}$ & $\mathrm{Si}$ \\
\hline $\begin{array}{l}1 \\
2 \\
3 \\
4\end{array}$ & $\begin{array}{l}\text { Core 1-Run 1 } \\
\text { Core 1-Run 2 } \\
\text { Core 2-Run 1 } \\
\text { Core 2-Run 2 }\end{array}$ & $\begin{array}{l}4 \\
4 \\
4 \\
4\end{array}$ & $\begin{array}{l}6600 \\
8400 \\
9000 \\
9200\end{array}$ & $\begin{array}{l}4.30 \\
4.65 \\
5.10 \\
5.30\end{array}$ & $\begin{array}{l}6400 \\
6400 \\
5600 \\
5600\end{array}$ & $\begin{array}{r}9.3 \\
18.6 \\
7.0 \\
6.7\end{array}$ & $\begin{array}{l}49 \\
55 \\
49 \\
51\end{array}$ \\
\hline $\begin{array}{l}\mathbf{5} \\
6 \\
7 \\
8 \\
\end{array}$ & $\begin{array}{l}\text { Core 3-Run 1 } \\
\text { Core 3-Run 2 } \\
\text { Core 4-Run 1 } \\
\text { Core 4-Run 2 }\end{array}$ & $\begin{array}{l}4 \\
4 \\
4 \\
8\end{array}$ & $\begin{array}{r}9600 \\
9700 \\
10,000 \\
9900 \\
\end{array}$ & $\begin{array}{l}5.95 \\
6.30 \\
7.15 \\
7.20 \\
\end{array}$ & $\begin{array}{l}4400 \\
4350 \\
3500 \\
3400 \\
\end{array}$ & $\begin{array}{l}.5 \\
.4 \\
.2 \\
.2 \\
\end{array}$ & $\begin{array}{l}44 \\
42 \\
28 \\
30 \\
\end{array}$ \\
\hline
\end{tabular}

The monitoring data for experiment 3 is shown in table 19. The $\mathrm{pH}$ data suggested that carbonate dissolution was initially rapid during the first pass of the waste through the core. Only small incremental changes in waste $\mathrm{pH}$ were observed with the second pass through the same core. The Fe data again showed the dramatic effect of $\mathrm{pH}$ on $\mathrm{Fe}$ solubilization. At $\mathrm{pH}$ values below $5, \mathrm{Fe}$ dissolution was rapid, was moderate between $\mathrm{pH} 5$ and 6 , and was essentially zero above $\mathrm{pH}$ 6 . Silica solubilization by the waste showed the typical $\mathrm{U}$-shaped curve for silica solubility (Jones and Handreck, 1967). Silica solubility was high at low $\mathrm{pH}$ and decreased gradually with increasing $\mathrm{pH}$. Silica solubility would be expected to again increase with $\mathrm{pH}$ above $\mathrm{pH} 10$.

The concentration of phthalic, terephthalic, and $p$-toluic acids at the end of the experiments were 27, 87 , and $151 \mathrm{mg} / \mathrm{l}$, respectively. The resultant ratio of these three compounds were 1.0:3.2:5.6, which is very different from the 1.0:2.1:3.1 ratio that they appear in the injected waste. The low concentrations of all acids indicate sorption on the aquifer material and the ratio indicated preferential sorption of phthalic acid.

An additional experiment was designed to test the hypothesis that $\mathrm{Fe}$ complexed with phthalic acid precipitated above $\mathrm{pH}$ 6.5. Solutions of phthalic acid $(0.001 M$ (molar) $=164 \mathrm{mg} / \mathrm{l})$ and $\mathrm{FeCl}_{3}(0.01 M=590$ $\mathrm{mg} / \mathrm{l}$ ) were mixed at $\mathrm{pH} 2.8$. These concentrations are similar to phthalic acid concentrations in the waste and the experimental concentration range of $\mathrm{Fe}$ with waste passage within the aquifer as determined in the previously discussed laboratory experiments. The $\mathrm{pH}$ was increased to 6.5 by small additions of dilute $\mathrm{NaOH}$. Iron and Fe-phthalic acid complex precipitated from solution. Gas chromatographic analysis on the supernatant solution indicated that over 50 percent of the phthalic acid was removed from solution into the precipitated phase.
The sorptive capacities for phthalic, terephthalic, and $p$-toluic acids during experiment 3 are $0.01,0.02$, and $0.03 \mathrm{mg} / \mathrm{g}$ of aquifer material. These sorptive capacities are relative and not absolute sorptive capacities because they were computed on the basis of $1,600 \mathrm{~g}$ of aquifer core material (four cores) used during the experiment. A more correct sorptive capacity is believed to be $0.02,0.02$, and 0.03 because phthalic acid was only sorbed on the last two cores of the experiment $(800 \mathrm{~g}$ of sediment) when the $\mathrm{pH}$ was above $\mathrm{pH}$ 6 ; whereas terephthalic and $p$-toluic acids were sorbed by all the cores. This conclusion is also supported by the sorptive data and curves as shown in table 12 and Figure 32, respectively, where phthalic acid is only sorbed between $\mathrm{pH} 6-7$, but terephthalic and $p$-toluic acids are sorbed over the entire $\mathrm{pH}$ range of experiment 1.

The sorptive capacities of phthalic, terephthalic, and $p$-toluic acids as determined during experiment $3(0.02$, 0.02 , and $0.03 \mathrm{mg} / \mathrm{g}$ ) by waste monitoring, during experiment $2(0.02,0.10$, and 0.10$)$ by sediment extraction, and the sorptive curves in figure 31 during experiment 1 may mistakenly be interpreted to be in conflict. The differences really reflect the dependence of sorptive capacity on $\mathrm{pH}$, the nature of the sorptive site, and the charge on the organic molecule. The composition of the reactive surface, its charge, and charge density, change with dissolution of $\mathrm{Fe}, \mathrm{SiO}_{2}$, and $\mathrm{Al}$. The reactive surfaces are primarily amorphous coatings of $\mathrm{Fe}, \mathrm{Al}, \mathrm{Mn}$, and $\mathrm{SiO}_{2}$ at the beginning of the experiments when $\mathrm{pH}$ is high. With dissolution of these coatings and carbonates, the reactive surface gradually becomes a more crystalline alumino-silicate clay mineral and crystalline sesquioxide surface. The $\mathrm{pH}$ within the core also gradually becomes more acidic.

The solubility of the aromatic acids, their hydrophilic character, and negative charge (acid dissociation) decreases with decreasing $\mathrm{pH}$. The relative rate of magnitude of these changes are dependent on the configuration of the molecule and the relative changes in the reactive surface. All data indicate that phthalic acid is preferably sorbed at high $\mathrm{pH}$ whereas $p$-toluic and terephthalic acids are preferably sorbed at lower $\mathrm{pH}$ with less $\mathrm{Fe}$ on the reactive surfaces.

The 0.15 percent organic carbon component of the native aquifer material is also an important factor in organic waste acid sorption by the core. Many organic compounds have a profound affinity or attraction for like or similar compounds. The amphoteric nature of natural organic substances would facilitate organic acid sorption through the entire $\mathrm{pH}$ range of the experiments (pH 3.7-8.2) by hydrogen bonding, Van der Waals forces, or direct exchange processes.

The bridge bonding of $\mathrm{Fe}, \mathrm{Al}$, and $\mathrm{Mn}$ on the core colloids to organic acids in the interstitial waste liquid 
was also an important possibility of organic acid sorption. The acidic functional group on the organic acid could actively participate in initial Fe solubilization by surface complexation with Fe. With time, decreasing $\mathrm{pH}$ (increased protonation potential), and increasing organic acid concentration, the $\mathrm{Fe}$ would leave the surface of the colloid and become sequestered by the organic acid. The active solubilization period or time which the organic acid was in contact with the Fe on the surface site would be manifested as organic acid sorption.

\section{FINAL CONCEPTUAL MODEL OF WASTE MOVEMENT AND REACTIVITY}

The final conceptual model of waste movement and reactivity was more complex and detailed than the initial hypothetical model. The initial model assumed waste movement within a single permeable injection zone; however, the logs and the observation well flowtest indicated that the injection zone consists of multiple subzones. Assuming independent subzones within the injection zone as shown in figure 33 , the waste possibly moved preferentially into the upper subzones because of favorable permeability and because the density of the waste is less than that of the ground water. This density effect is shown in figure 33 by having the lighter waste solution overriding the heavier ground water in the lower two receiving subzones within the injection zone. The flow system diagrammed in figure 33 is but one of many possibilities discussed in connection with figure 21. Therefore, waste obtained from observation wells may be diluted by the ground water within the waste-contaminated subzone because of the density separation. Most of the variance in the waste concentrations in samples obtained from wells 11, 14, and 15 is believed to have been due to changing dilution factors caused by changing circulation patterns between the waste-receiving subzones within the observation wells.

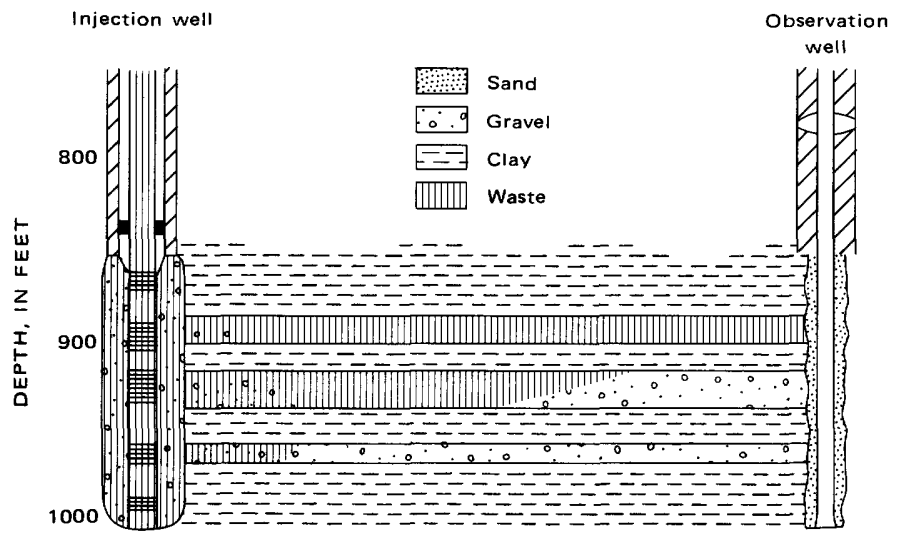

FIGURE 33.-Hypothetical movement of injected waste within injection subzones.
Evidence that all the receiving subzones within the injection zone were accepting waste was obtained from wells $1,2,4$, and 5. Samples obtained from these wells which were located only $150 \mathrm{ft}(46 \mathrm{~m})$ from injection well I-6 were essentially free of ground water. The large distance gap between the observation wells of the initial injection network and the observation wells of the expanded system did not allow observation of the injection zone in regions where the injected waste interfaced with the native ground water in the lower receiving subzones. Therefore, the distance of injected-waste travel in these lower subzones is purely speculative in figure 33.

Many of the postulations in the initial conceptual model (fig. 17) are valid for the final conceptual model shown in figure 34 . This model, based on the findings of this study, shows features of waste movement and reactivity within an individual waste-receiving subzone in the injection zone. Figure 34 does not show vertical distribution of waste in an aquifer, but the percentage of waste at a particular distance from the injected well. Therefore, this model probably has different quantitative dimensions for each receiving subzone depending on the distance and rate of waste travel within each subzone. However, the relative dimensions and order of reactivity should have validity for each subzone. As with the initial model, the dimensions of this model expand to the right with increasing time during waste injection.

This final model is divided into a "waste front" and "waste interior" at the point where the $\mathrm{pH}$ of the injected waste begins to rise through neutralization reactions. Most, but not all of the ground water has been displaced from the receiving subzone at this point. The curve, relative percentage of waste to percentage of groundwater, was drawn with the ground water extending the waste-contaminated region because the density difference between the injected waste and the

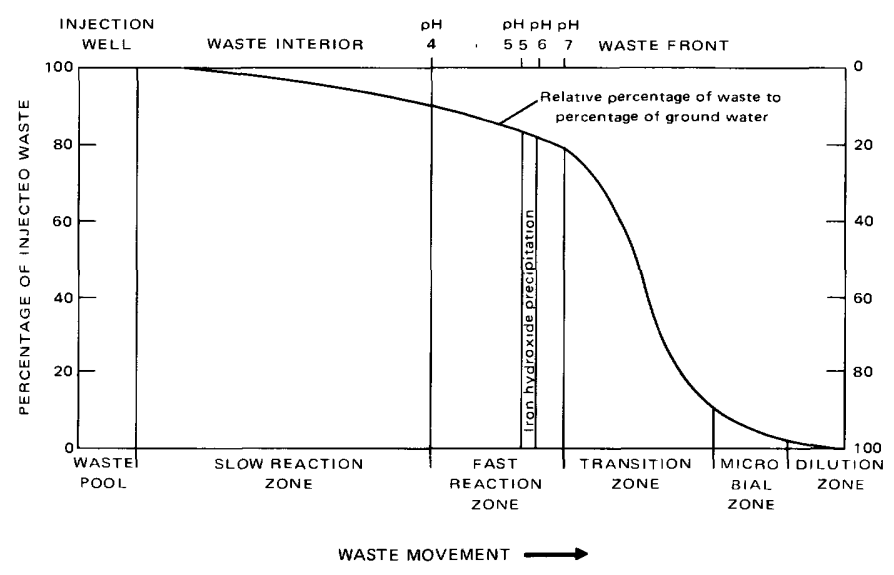

FIGURE 34.-Final conceptual model of injected-waste reactivity and movement. 
native ground water would cause stratification and prevent rapid mixing.

The leading zone of the waste front prior to the appearance of methane gas indicative of microbial activity is called the "dilution zone" because the neutralized ( $\mathrm{pH} \mathrm{7)}$ waste appears as a very dilute solution in ground water. Data from samples obtained from wells 11 and 14 indicated that waste concentrations had to attain a certain threshold value before there was microbial waste decomposition. This zone may also represent a lag time during which the microorganisms are multiplying to numbers where they become significant in waste decomposition. The waste showed no detectable reactions within this zone, and had little effect on the chemical quality of the ground water.

The zone which follows the dilution zone is called the "microbial activity zone" because of indications of anaerobic waste transformations within this zone. Methane gas, sulfur reduction, and iron reduction were observed either singly or in combination at various periods in wells 11,14 , and 15 . Two strains of methane-producing organisms were isolated in samples obtained from well 14 during methane production. However, the microbiological study revealed that the waste was toxic to microorganisms in moderate concentrations, and waste decomposition occurred only at the periphery of the waste front where waste concentrations were low.

The zone called the "transition zone" follows the microbial activity zone. When the waste attains toxic concentrations and when limiting nutrients such as nitrogen are gone, there will be a die-off of microorganisms in the injection zone and microbial activity will cease. This zone is transitional between the zone of microbial waste transformations and the zone in which chemical reactions predominate.

Most of the chemical waste-aquifer interactions were found to occur within the zone defined as the "fastreaction zone". The boundaries of this zone are defined by $\mathrm{pH}$. The $\mathrm{pH}$ changes from $\mathrm{pH} 4$ at the trailing boundary to $\mathrm{pH} 7$ at the leading boundary. One of the main features of this zone is the neturalization of the acidic, injected waste at $\mathrm{pH} 4$ by the aquifer carbonates and sesquioxide minerals. Observations on site at well 9 and in experiments 1 and 2 of the laboratory wasteaquifer reactivity studies indicate that at a given point in receiving zone, the maximum rate of dissolution of carbonate coatings occurs first followed by dissolution of sesquioxide coatings of which the iron oxides predominate. Dissolution of both carbonates and $\mathrm{Al}, \mathrm{SiO}_{2}$, $\mathrm{Fe}$, and $\mathrm{Mn}$ contained within the grains of primary minerals occurs at a much slower rate than the dissolution of the coatings. High concentrations of dissolved calcium and carbon dioxide are features of carbonate dissolution, and sesquioxide dissolution is indicated by elevated concentrations of aluminum, iron, and manganese.

Iron solubilization data from experiments 1 and 2, and iron precipitation data from experiment 3 , suggest a region of iron hydroxide precipitation within the fast-reaction zone. As the $\mathrm{pH}$ of a unit of waste moving outwards from the injection well changes from $\mathrm{pH} \mathbf{5 . 5}$ to 6.0 , hydroxide concentration increases to the point where precipitation of iron hydroxide occurs. This region of iron hydroxide precipitation may be a significant factor in the chemical plugging of the wastereceiving subzones because very high concentrations of organically complexed iron were observed in the fastreaction zone below $\mathrm{pH} 5.5$, and this dissolved iron was essentially quantitatively reprecipitated as the $\mathrm{pH}$ of the injected waste rose during its outward movement and neutralization. Phthalic acid complexed with the dissolved iron was found to be coprecipitated with the iron hydroxide, and this is most likely the reason why phthalic acid was not found in the neutralized waste samples obtained from wells 11,14 , and 15 . The correlation of iron concentration with waste concentration in well 14 most likely resulted from bacterial waste decomposition processes; not from organic acid dissolution of iron oxide coatings because acid-solubilized iron should have reprecipitated before the waste reached well 14.

The laboratory waste-aquifer study substantiated the "slow-reaction zone" of the initial conceptual model which follows the fast-reaction zone. Reactions which occur in this zone are the slow solubilization of silica, aluminum, and iron from the crystalline primary minerals found in the waste-receiving subzones. Prior passage of acidic waste has dissolved most of the secondary coatings found on the aquifer minerals, and the only significant reactions which remain are the slowdissolution reactions of the primary minerals themselves. The $\mathrm{pH}$ in this zone is essentially the same as the $\mathrm{pH}$ of the injected waste, $\mathrm{pH} \mathrm{4}$, because the flow rates and types of reactions do not significantly neutralize the waste and affect the $\mathrm{pH}$.

The reaction rates in the slow-reaction zone were found to decrease as the quantity of injected waste increased until no further reactions could be observed between the waste and the aquifer constituents. The area in the subsurface in the immediate environs of the waste-injection well where there were no observable reactions was called the "waste pool." Samples obtained from wells $1,2,4$, and 5 at the beginning of this study were taken from the waste pool because their elemental composition was essentially the same as the injected waste. Only after the cessation of all observable reactions can the subsurface environment be regarded as a waste storage area because it is only in this waste pool that the waste could be reclaimed in unal- 
tered form after subsurface injection.

The various zones and interactions presented in this final conceptual model of waste movement and reactivity cannot be considered to be well defined at all times during waste injection. At the beginning of injection of waste similar to that from the Hercules plant, it is not likely that there is a microbial activity zone because conditions change too suddenly within the waste front for an establishment of a viable waste-degrading microbial population. It is only after the waste front has moved a significant distance from the injection well that its rate of movement will decrease to the point which allows the formation of a microbial activity zone. At the opposite extreme of the model, a waste pool cannot form until a sufficient volume of waste has been injected and enough time has passed so that all the reactive aquifer constituents have been dissolved and removed from the vicinity of the injection well. In summary, this model is a static representation of a dynamic situation. Specifically, this model was drawn to represent the various stages of reaction of the injected waste thought to exist in the subsurface after 4 years of waste injection at which time most of the findings of this study were obtained.

\section{SUMMARY AND CONCLUSIONS}

The Hercules waste injection site near Wilmington, N.C., has provided an opportunity for studying the physical, chemical, and biological aspects of subsurface organic waste injection. Most of the waste-aquifer interactions which were predicted to occur at the inception of this study were verified by the site and laboratory studies. Differences between the initial and final conceptual models of waste movement and reactivity show however that the initial predictive model had to be tested with data and modified to fit the findings of this study.

Evidence was obtained at the site and in laboratory studies to substantiate the following waste-aquifer interactions:

1. Dissolution of the carbonate minerals in the injection zone by the waste organic acids.

2. Dissolution of the sesquioxide coatings on the primary minerals in the injection zone by waste organic acids.

3. Dissolution of the primary aluminosilicate minerals in the injection zone by the waste organic acids.

4. Dissolution and complexation of iron and manganese oxides by the waste organic acids.

5. Reprecipitation of complexed dissolved iron during waste neutralization.

6. Coprecipitation of phthalic acid complexed with iron during iron hydroxide precipitation.

7. Methane gas production resulting from anaerobic microbial waste degradation.
8. Microbial reduction of sulfates to sulfides.

9. Reduction of ferric to ferrous iron resulting from decreases in Eh and $\mathrm{pH}$ due to microbial waste degradation.

10. Retention of organic waste acids by adsorption and anion exchange on the mineral constituents in the injection zone at low $\mathrm{pH}$ values.

These waste-aquifer interactions prove that this industrial organic waste cannot be regarded as an inert fluid which does not react after injection into the subsurface environment. The history of the plugging of both injection wells after a period of waste injection strongly indicates that serious consideration should be given to the chemical compatibility of the waste with the fluid and minerals of the zone into which injection is planned. Problems of injection zone plugging may be due in part to the reprecipitation of aquifer constituents initially dissolved by the waste acids, and due to the formation of gaseous reaction products such as carbon dioxide and methane. Dissolution of aquifer solids by the complexing organic acids in the waste may be significant in the leakage problems at the injection and observation wells. These organic acids may dissolve the bond between the cement grout surrounding the well casing and the aquiclude confining beds to allow upward leakage of waste into shallower zones. If the waste leakage was due to dissolution reactions, this problem would be accentuated at the injection wells where the waste is the most acid ( $\mathrm{pH} \mathrm{4}$ ), the warmest $\left(45^{\circ} \mathrm{C}\right)$, the density difference with the native ground water the greatest, and where the highest pressure head occurs in the injection zone.

This study has shown the importance of conducting compatibility tests of the injected waste with the aquifer material before the initiation of waste injection. The data obtained by conducting three experiments with the pressurization core-testing apparatus demonstrated that field hydraulic conditions of waste injection can be simulated within the laboratory. Most of the chemical interactions which occurred on-site were observed in the laboratory simulation of waste injection into cores of material from the injection zone. The laboratory study demonstrated precipitation and dissolution reactions which pointed to problems of aquifer plugging and leakage at the waste-injection site. It also better defined waste-aquifer interaction in a quantitative manner than did the site study. Such laboratory tests should also be of considerable interpretive value in waste-injection systems where monitor wells are absent or are determined to be a financially impractical part of the total injection system.

A major limitation of the site study was imposed by the construction features of the observation wells because they were open to various subzones within the 
injection zone. In any future study it would be desirable to install packers in the observation wells to isolate each subzone, so that undiluted samples could be obtained from each.

The case history of the Hercules waste-injection system is a documentation of a system which is no longer used for several reasons. The major problem with the waste appears to be its reactivity. Because the overall permeability of the waste-injection zone was low, the formation of coatings, precipitates, and (or) gases, even in small quantities, decreased the permeability of the injection zone to the point where plugging of the injection well occurred. If wastes of this type were neutralized prior to injection, the injected neutralized waste would not dissolve aquifer constituents such as iron which is later reprecipitated. Carbon dioxide gas would, therefore, not be formed which may constitute part of the plugging problem other than the small quantity produced by microbioal waste degradation. The neutralized salts of organic acids are not nearly adsorbed on aquifer sediments to the extent of free acids which may form coatings and precipitates on aquifer sediments. Cooling the neturalized waste prior to its filtration and injection would allow precipitate formation of any insoluble waste constitutents which could be filtered from the waste before injection. These actions would have made the waste more inert in the subsurface environment, thus minimizing problems with aquifer plugging and well leakage.

The microbiological study has shown that this injected waste is very slowly biodegradable in the subsurface environment. Although the addition of nitrogen to the injected waste may greatly increase the amount of microbial waste degradation and subsequent methane formation, a large amount of methane gas would undoubtedly be formed and would plug the injection zone under site conditions similar to that studied.

\section{SELECTED REFERENCES}

Black, Crow, and Eidsness, Inc., 1971, Engineering report on drilling and testing of additions to the disposal well system for Hercules Incorporated, Hanover Plant, Wilmington, N.C.: 103 p.

Bricker, C. E., and Vail, W. A., 1950, Microdetermination of formaldehyde with chromotropic acid: Anal. Chemistry, v. 22, no. 5, p. $720-722$.

DiTommaso, Anthony, and Elkan, G. H., 1973, Role of bacteria in decomposition of injected liquid waste at Wilmington, North Carolina, in J. Braunstein, ed., Sept. 1973, Underground Waste Management and Artificial Recharge: New Orelans, v. 1, p. 585-599.

Goerlitz, D. F., and Brown, Eugene, 1972, Methods for analysis of organic substances in water: U.S. Geol. Survey Techniques Water-Resources Inv., book 5, chap. A3, 40 p.
Hall, C. W., and Ballentine, R. K., 1973, U.S. Environmental Protection Agency policy on subsurface emplacement of fluids by well injection, in J. Braunstein, ed., Sept. 1973, Underground Waste Management and Artificial Recharge: New Orleans, v. 2, p. 783-789.

Hem, J. D., 1970, Study and interpretation of the chemical characteristics of natural water [2d ed.]: U.S. Geol. Survey WaterSupply Paper 1473, 363 p.

Jones, L. H. P., and Handreck, K. A., 1967, Silica in soils, plants and animals: Advances in Agronomy, v. 19, p. 107-147.

Kunzie, G. W., and Rich, C. I., 1959, Certain properties of some Southeastern United States soils and mineralogical procedures for their study: Blackburg, Va., Virginia Agr. Exp. Sta., Southern Cooperative Series Bull. 61.

Lawrence, A. W., and McCarthy, P. L., 1969, Kinetics of methane fermentation in anaerobic treatment: Water Pollution Control Federation Jour., v. 1, part 2, p. 1-17.

Leenheer, J. A., and Malcolm, R. L., 1973a, Chemical and microbial transformations of an industrial organic waste during subsurface injection: Anaheim, Calif., Inst. Environmental Sci. Proc., April 1973, p. 351-360.

$1973 \mathrm{~b}$, Case history of subsurface waste injection of an industrial organic waste, in J. Braunstein, ed., Sept. 1973, Underground Waste Management and Artificial Recharge: New Orleans, v. 1, p. 565-584.

Le Grand, H. E ., 1955, Brackish water and its structural implications in Great Carolina Ridge, North Carolina: Am. Assoc. Petroleum Geologists Bull., v. 39, no. 10, p. 2020-2037.

-1960 , Geology and ground-water resources of WilmingtonNew Bern area: North Carolina Dept. Water Resources Ground-Water Bull. 1, 80 p.

Malcolm, R. L., Leenheer, J. A., 1973, The usefulness of organic carbon parameters in water quality investigations: Anaheim, Calif., Inst. Environmental Sci. Proc., April 1973, p. 336-340.

Malcolm, R. L., Leenheer, J. A., McKinley, P. W., and Eccles, L. A., 1973, Supplement II-Dissolved organic carbon, in D. F. Goerlitz and Eugene Brown, eds., Methods for analysis of organic substances in water: U.S. Geol. Survey Techniques WaterResources Inv., book 5, chap. A3, 34 p.

Malcolm, R. L., Leenheer, J. A., and Weed, S. B., 1976, Dissolution of aquifer clay minerals during deep-waste disposal of industrial organic wastes: Mexico City, Internat. Clay Conf. Proc., 1975, p. 477-493.

McKeague, J. A., and Cline, M. G., 1963, Silica in soil solutions, Parts I and II: Canadian Jour. Soil Sci., v. 43, p. 70-96.

McKenzie, H. A., and Wallace, H., 1954, The Kjeldahl of nitrogen: A critical study of digestion conditions: Australian Jour. Chem., v. 7, p. 55-60.

Mehra, O. P., and Jackson, M. L., 1960, Iron-oxide removal from soils and clays by a dithionite-citrate system buffered with sodium bicarbonate: Clays and Clay Minerals, 7th Natl. Conf. on Clays and Clay Min. Proc., 1960, p. 317-327.

North Carolina Department of Water and Air Resources, 1971, Satus report on the feasibility of the injection of liquid waste into saline ground water at Wilmington, North Carolina: Raleigh, North Carolina, $26 \mathrm{p}$.

Oborn, E. T., and Hem, J. D., 1961, Microbiologic factors in the solution and transport of iron: U.S. Geol. Survey Water-Supply Paper 1459-H, p. 213-235.

Peek, H. M., and Heath, R. C., 1973, Feasibility study of liquid-waste injection into aquifers containing salt water, Wilmington, North Carolina, in J. Braunstein, ed., Sept. 1973, Underground Waste Management and Artificial Recharge: New Orleans, v. 2, p. 851-875.

Ringbom, A., 1963, Complexation in analytical chemistry: New York, Interscience Publishers, $395 \mathrm{p}$.

Siebert, M. L., and Hattingh, W. H. J., 1967, Estimation of methane-producing bacterial numbers by the most probable number (MPN) technique: Pergammon Press, Water Research, v. 1, p. 13-19. 
Skougstad, M. W., and Scarbro, G. F., Jr., 1968, Water sample filtration unit: Environmental Sci. and Technology, v. 2, p. 298-301.

Swenson, H. A., and Baldwin, A. L., 1965, A primer on water quality: Washington, U.S. Govt. Printing Office, 27 p.

Waksman, S. A., 1952, Soil microbiology: New York, John Wiley \& Sons, 356 p.
Warner, D. L., and Orcutt, D. H., 1973, Industrial waste-water wells in United States-Status of use and regulation, 1973, in J. Braunstein, ed., Sept. 1973, Underground Waste Management and Artificial Recharge: New Orleans, v. 2, p. 687-697.

White, W. R., and Leenheer, J. A., 1975, Determination of free formic and acetic acids by gas chromatography using the flame ionization detector: Jour. Chromatographic Sci., v. 13, p. 386-389. 



\section{BASIC-DATA TABLES 20-36}


TABLE 20. - Organic waste analyses

\begin{tabular}{|c|c|c|c|}
\hline & \multicolumn{3}{|c|}{ Collection date (mo-day-yr) } \\
\hline & $9-14-72$ & $7-6-73$ & $11-7-73$ \\
\hline & \multicolumn{3}{|c|}{ Milligrams per litre } \\
\hline $\begin{array}{l}\text { DOC } \\
\text { Acetic acid } \\
\text { Formic acid } \\
\text { Formaldehyde } \\
\text { Methanol }\end{array}$ & $\begin{array}{r}6,700 \\
9,500 \\
3,100 \\
1,600 \\
260\end{array}$ & $\begin{array}{r}6,400 \\
8,500 \\
3,300 \\
1,700 \\
0\end{array}$ & $\begin{array}{r}7,900 \\
10,000 \\
2,900 \\
2,100 \\
2,000\end{array}$ \\
\hline 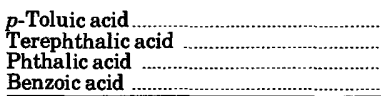 & $\begin{array}{r}1,200 \\
430 \\
36 \\
35\end{array}$ & $\begin{array}{r}1,100 \\
400 \\
22 \\
32\end{array}$ & $\begin{array}{r}1,000 \\
360 \\
170 \\
95\end{array}$ \\
\hline
\end{tabular}

TABLE 21. - Waste inorganic analyses - sample collected 11-7-73 [Analyzed by WRD Central Laboratory, Salt Lake City, Utah, except where noted by (a),
Huuftman Laboratory, Wheatridge, Colo., or by (b), V.C. Kennedy, U.S.G.S., Menlo Park, Calif.1

\begin{tabular}{|c|c|c|c|}
\hline & \multicolumn{3}{|c|}{ Analysis date } \\
\hline & $12-18-73$ & 3-27-74 & \\
\hline $\begin{array}{l}\text { pH } \\
\text { Specific conductance } \\
\left(\mu \text { mhos at } 25^{\circ} \mathrm{C}\right)\end{array}$ & $\begin{array}{l}3,8.8 \\
4,560\end{array}$ & 4,530 & \\
\hline & \multicolumn{3}{|c|}{ Milligrams per litre } \\
\hline $\begin{array}{l}\text { Silica }\left(\mathrm{SiO}_{2}\right) \\
\mathrm{Calcium}(\mathrm{Ca}) \\
\text { Magnesium }(\mathrm{Mg}) \\
\text { Sodium }(\mathrm{Na}) \\
\text { Potassium }(\mathrm{K})\end{array}$ & $\begin{array}{c}31 \\
1,300 \\
30 \\
1.8 \\
-\end{array}$ & $\begin{array}{r}31 \\
1,300 \\
32 \\
1.5 \\
3.8\end{array}$ & \\
\hline $\begin{array}{l}\text { Sulfate }\left(\mathrm{SO}_{4}\right) \\
\text { Chloride }(\mathrm{Cl}) \\
\text { Fluoride }(\mathrm{F}) \\
\text { Nitrite-nitrate }\left(\mathrm{NO}_{2}-\mathrm{NO}_{2}\right) \\
\text { Orthophospate }\left(\mathrm{PO}_{4}\right) \\
\text { Hardness as } \mathrm{CaCO}_{3}(\mathrm{Ca}, \mathrm{Mg}) \\
\end{array}$ & $\begin{array}{c}11 \\
5.2 \\
1.4 \\
\overline{0} .28 \\
3,400\end{array}$ & $\begin{array}{r}41 \\
5.5 \\
2.8 \\
\overline{\bar{T}} \\
3,400\end{array}$ & 3.9(a) \\
\hline & \multicolumn{3}{|c|}{ Micrograms per litre } \\
\hline 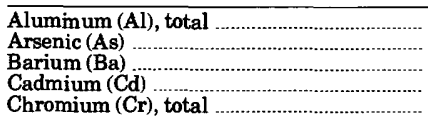 & $\begin{array}{r}\overline{3} \\
0 \\
5 \\
260\end{array}$ & $\bar{z}$ & $6,200(\mathrm{~b})$ \\
\hline $\begin{array}{l}\text { Cobalt (Co) } \\
\text { Copper (Cu) } \\
\text { lron (Fe), total } \\
\text { Lead }(\mathrm{Pb}) \\
\text { Manganese (Mn) }\end{array}$ & $\frac{1,600}{\overline{20}}$ & $\begin{array}{r}100 \\
80 \\
7 \\
80\end{array}$ & $5,500(\mathrm{~b})$ \\
\hline $\begin{array}{l}\text { Mercury (Hg), total } \\
\text { Molybdenum (Mo) } \\
\text { Nickel (Ni) } \\
\text { Selenium (Se) } \\
\text { Strontium (Sr) } \\
\text { Zinc (Zn) } \\
\end{array}$ & $\begin{array}{l}1.0 \\
2 \\
100 \\
24 \\
820\end{array}$ & $\frac{\overline{2}}{5 \overline{9}}$ & \\
\hline
\end{tabular}

TABLE 22. - Inorganic analyses of ground water from surficial sand aquifer

\begin{tabular}{|c|c|c|c|c|}
\hline \multirow{5}{*}{ 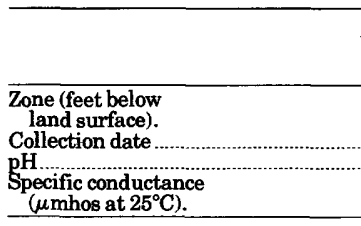 } & \multicolumn{4}{|c|}{ Well } \\
\hline & $\begin{array}{c}\text { Hercules } \\
\text { Supply well C }\end{array}$ & C $\quad 14$ & 15 & $\frac{16}{33-53}$ \\
\hline & $30-60$ & $28-48$ & $33-53$ & $33-53$ \\
\hline & 6-15-71 & $2-25-72$ & $2-26-72$ & 5-19-72 \\
\hline & 29.0 & $\begin{array}{l}6.6 \\
46\end{array}$ & 85 & $31^{6.0}$ \\
\hline & \multicolumn{4}{|c|}{ Milligrams per litre } \\
\hline $\begin{array}{l}\text { Silica }\left(\mathrm{SiO}_{2}\right) \\
\mathrm{Calccium}(\mathrm{Ca}) \\
\text { Magnesium }(\mathrm{Mg}) \\
\text { Sodium (Na) } \\
\text { Potassium (K) }\end{array}$ & $\begin{array}{r}5.0 \\
1.8 \\
.4 \\
3.0 \\
.5\end{array}$ & $\begin{array}{r}4.8 \\
2.0 \\
1.0 \\
4.9 \\
.6\end{array}$ & $\begin{array}{l}5.7 \\
5.0 \\
3.0 \\
4.5 \\
1.4\end{array}$ & $\begin{array}{r}4.1 \\
1.5 \\
.9 \\
2.1 \\
.5\end{array}$ \\
\hline $\begin{array}{l}\text { Bicarbonate }\left(\mathrm{HCO}_{3}\right) \\
\text { Sulfate }\left(\mathrm{SO}_{4}\right) \\
\text { Chloride }(\mathrm{C}) \\
\text { Fluoride } \\
\text { Nitrite-nitrate }\left(\mathrm{NO}_{2}-\mathrm{NO}_{3}\right)\end{array}$ & $\begin{array}{l}4 \\
4.0 \\
5.2 \\
0 \\
\quad .2\end{array}$ & $\begin{array}{r}10 \\
2.4 \\
6.4 \\
.0 \\
.3\end{array}$ & $\begin{array}{l}5 \\
2.6 \\
9.0 \\
.0 \\
4.3\end{array}$ & $\begin{array}{l}7 \\
4.4 \\
3.4 \\
.0 \\
.02\end{array}$ \\
\hline $\begin{array}{l}\text { Orthophosphate }\left(\mathrm{PO}_{4}\right) \\
\text { Residue on evaporation } \\
\text { at } 180^{\circ} \mathrm{C} \text {. }\end{array}$ & $22^{.00}$ & $33^{.000}$ & $56^{.013}$ & $29^{.010}$ \\
\hline \multirow[t]{2}{*}{ Hardness as $\mathrm{CaCO}_{3}(\mathrm{Ca}, \mathrm{Mg})$} & 6 & 9 & 25 & 7 \\
\hline & \multicolumn{4}{|c|}{ Micrograms per litre } \\
\hline (Al), total ...................... & $\begin{array}{l}53 \\
57\end{array}$ & $\begin{array}{l}107 \\
115\end{array}$ & 37 & $\begin{array}{l}239 \\
131\end{array}$ \\
\hline & 12 & & - & 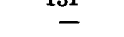 \\
\hline $\begin{array}{l}\text { Copper }(\mathrm{Cu}) \\
\text { Zinc }(\mathrm{Zn})\end{array}$ & $\begin{array}{l}40 \\
10\end{array}$ & 二 & 二 & $\bar{z}+\mathrm{r}+\mathrm{r}+\mathrm{r}+\mathrm{c}$ \\
\hline
\end{tabular}

TABLE 23.-Inorganic analyses of ground water from 300-ft zone

\begin{tabular}{|c|c|c|c|c|}
\hline & \multicolumn{4}{|c|}{ Well No. } \\
\hline & 13 & 14 & 15 & 16 \\
\hline \multirow{4}{*}{$\begin{array}{l}\text { Zone (feet below } \\
\text { land surface). } \\
\text { Collection date. } \\
\text { pH } \\
\text { Specific conductance } \\
\left.\text { ( } \text { mhos at } 25^{\circ} \mathrm{C}\right) . \\
\end{array}$} & $283-293$ & $320-330$ & $279-299$ & $305-325$ \\
\hline & $11-3-71_{3}$ & $2-25-72$ & 2-26-72 & 4-15-72 \\
\hline & & & & \\
\hline & \multicolumn{4}{|c|}{ Milligrams per litre } \\
\hline $\begin{array}{l}\text { Silica (SiO } \\
\text { Calcium (Ca) } \\
\text { Magnesium (Mg) } \\
\text { Sodium (Na) } \\
\text { Potassium (K) }\end{array}$ & $\begin{array}{c}2.3 \\
32 \\
34 \\
1850 \\
120\end{array}$ & $\begin{array}{r}9.7 \\
19 \\
46 \\
2000 \\
58\end{array}$ & $\begin{array}{r}9.5 \\
13 \\
32 \\
1650 \\
50\end{array}$ & $\begin{array}{r}11 \\
47 \\
45 \\
2100 \\
63\end{array}$ \\
\hline $\begin{array}{l}\text { Bicarbonate }\left(\mathrm{HCO}_{3}\right) \\
\text { Sulfate }\left(\mathrm{SO}_{4}\right) \\
\text { Chloride }(\mathrm{Cl}) \\
\text { Fluoride } \\
\text { Nitrite-nitrate }\left(\mathrm{NO}_{2}-\mathrm{NO}_{3}\right)\end{array}$ & $\begin{array}{r}611 \\
45 \\
2820 \\
1.3 \\
.2\end{array}$ & $\begin{array}{c}587 \\
350 \\
2780 \\
1.3 \\
.02\end{array}$ & $\begin{array}{r}634 \\
130 \\
2350 \\
1.4 \\
.6\end{array}$ & $\begin{array}{c}480 \\
330 \\
2480 \\
1.3 \\
.05\end{array}$ \\
\hline $\begin{array}{l}\text { Orthophosphate }\left(\mathrm{PO}_{4}\right) \\
\text { Residue on evaporation }\end{array}$ & $5220^{.02}$ & $5560^{.000}$ & $4560^{.000}$ & $5970^{.000}$ \\
\hline \multirow{2}{*}{ Hardness as $\mathrm{CaCO}_{2}(\mathrm{Ca}, \mathrm{Mg})$} & 200 & 236 & 164 & 303 \\
\hline & \multicolumn{4}{|c|}{ Micrograms per litre } \\
\hline$\cdots$ & 81 & 269 & 225 & 543 \\
\hline & $\begin{array}{r}173 \\
5253\end{array}$ & 15 & 0 & \\
\hline & $\begin{array}{r}5253 \\
77\end{array}$ & 15 & & 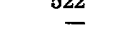 \\
\hline & 112 & - & - & - \\
\hline Zine $\left(Z_{n}\right)$ & 1200 & $\bar{z} \cdot r \cdot r \cdot r \cdot r \cdot 1$ & $\bar{z} \cdot r+r \cdot r \cdot r$ & $\bar{z}$ \\
\hline
\end{tabular}

TABLE 24.-Inorganic analyses of ground water from 500-ft zone

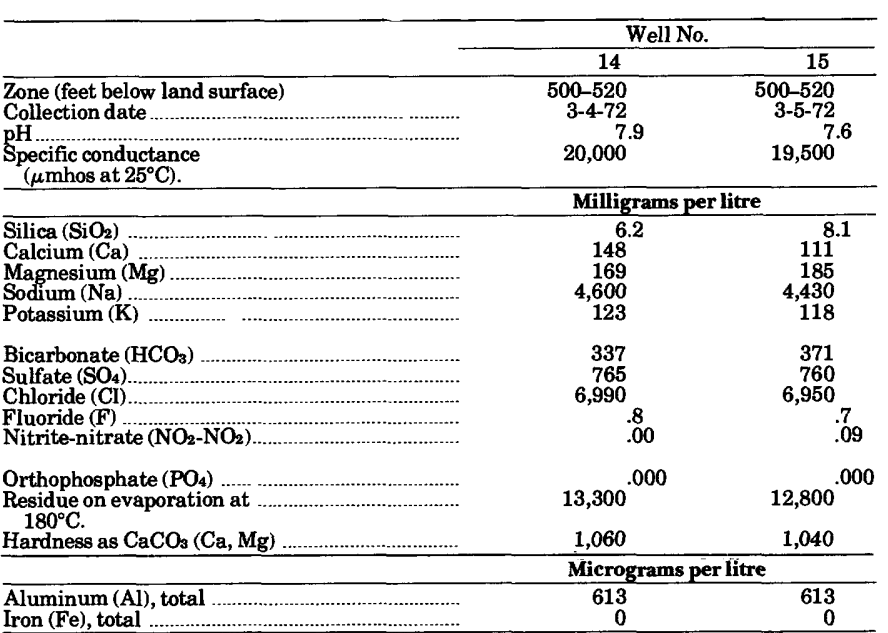


TABLE 25 - Inorganic analyses of ground water from 700-ft zone [Values in parentheses are from analysis by E. A. Jenne, U.S.G.S., Menlo Park, Calif.]

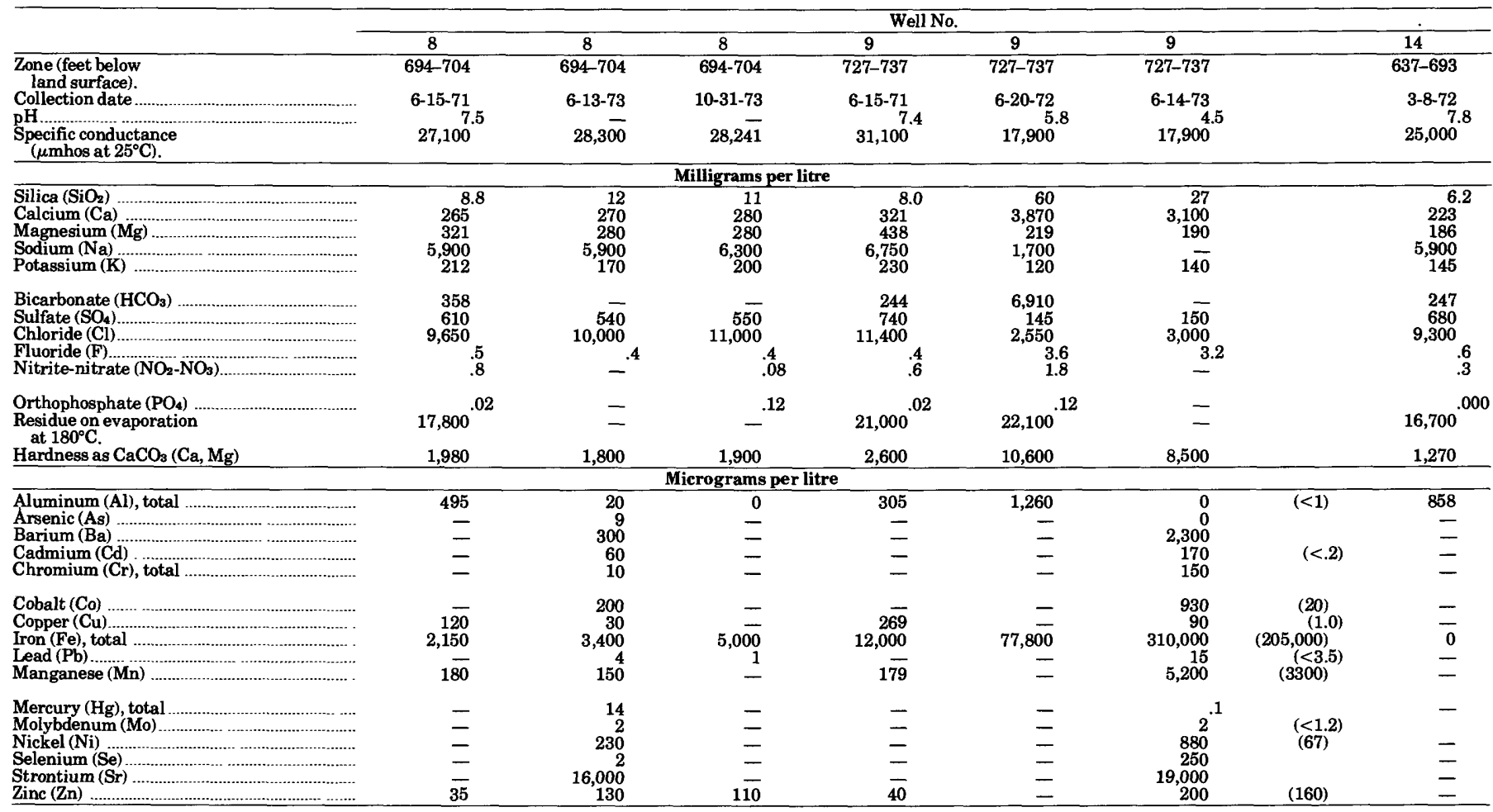

TABLE 26.-Inorganic analyses of ground water from well 7, 805-1036 feet below land surface

\begin{tabular}{|c|c|c|c|c|}
\hline \multirow[b]{2}{*}{$\begin{array}{l}\mathrm{pH} \\
\text { Specific conductance } \\
\left(\mu \text { mhos at } 25^{\circ} \mathrm{C}\right) \text {. }\end{array}$} & \multicolumn{4}{|c|}{ Collection date } \\
\hline & $\begin{array}{c}6-15-71 \\
7.5 \\
31,800\end{array}$ & $\begin{array}{c}11-3-71 \\
7.3 \\
32,500\end{array}$ & $\begin{array}{r}6-13-73 \\
31,500\end{array}$ & $\frac{10-31-73}{32,635}$ \\
\hline & \multicolumn{4}{|c|}{ Milligrams per litre } \\
\hline $\begin{array}{l}\text { Silica }\left(\mathrm{SiO}_{2}\right) \\
\text { Calcium }(\mathrm{Ca}) \\
\text { Magnesium }(\mathrm{Mg}) \\
\text { Sodium }(\mathrm{Na}) \\
\text { Potassium }(\mathrm{K})\end{array}$ & $\begin{array}{c}9.4 \\
353 \\
370 \\
6,900 \\
224\end{array}$ & $\begin{array}{r}11 \\
346 \\
315 \\
6,750 \\
155\end{array}$ & $\begin{array}{r}11 \\
330 \\
300 \\
6,700 \\
190\end{array}$ & $\begin{array}{r}11 \\
340 \\
300 \\
7,000 \\
210\end{array}$ \\
\hline $\begin{array}{l}\text { Bicarbonate }\left(\mathrm{HCO}_{3}\right) \\
\text { Sulfate }\left(\mathrm{SO}_{4}\right) \\
\text { Chloride }(\mathrm{Cl}) \\
\text { Fluoride }(\mathrm{F}) \\
\text { Nitrite-nitrate }\left(\mathrm{NO}_{2}-\mathrm{NO}_{2}\right)\end{array}$ & $\begin{array}{r}233 \\
385 \\
12,000 \\
.5 \\
.3\end{array}$ & $\begin{array}{c}231 \\
280 \\
12,000 \\
0\end{array}$ & $\begin{array}{c}2 \overline{270} \\
12,000 \\
-\end{array}$ & $\begin{array}{r}\overline{270} \\
12,000 \\
.3 \\
.11\end{array}$ \\
\hline $\begin{array}{l}\text { Orthophosphate }\left(\mathrm{PO}_{4}\right) \\
\text { Residue on evaporation } \\
\text { Hardness as } \mathrm{CaCO}_{3}(\mathrm{Ca}, \mathrm{Mg}) \ldots \ldots \ldots \\
\end{array}$ & $21,100.02$ & $20,700^{.03}$ & $2, \overline{\overline{0}}$ & $2, \overline{\overline{00}}^{.08}$ \\
\hline & \multicolumn{4}{|c|}{ Micrograms per litre } \\
\hline $\begin{array}{l}\text { Aluminum (Al), total } \\
\text { Arsenic (As) } \\
\text { Barium (Ba) } \\
\text { Cadmium (Cd) } \\
\text { Chromium (Cr), total }\end{array}$ & $\begin{array}{l}502 \\
\overline{-} \\
=\end{array}$ & $\begin{array}{l}335 \\
= \\
-\end{array}$ & $\begin{array}{r}0 \\
6 \\
400 \\
80 \\
20\end{array}$ & $\begin{array}{l}10 \\
= \\
-\end{array}$ \\
\hline $\begin{array}{l}\text { Cobalt }(\mathrm{Co}) \\
\text { Copper }(\mathrm{Cu}) \\
\text { Iron (Fe), total } \\
\text { Lead }(\mathrm{Pb})\end{array}$ & $\overline{3 \overline{14}}$ & $\begin{array}{r}2 \overline{11} \\
1,792 \\
-\end{array}$ & $\begin{array}{r}250 \\
40 \\
1,400 \\
3\end{array}$ & $\begin{array}{r}\overline{-} \\
1,300 \\
0\end{array}$ \\
\hline $\begin{array}{l}\text { Lithium (Li) } \\
\text { Manganese (Mn) } \\
\text { Mercury (Hg), total } \\
\text { Molybdenum (Mo) }\end{array}$ & $\overrightarrow{222}$ & $\begin{array}{r}292 \\
190 \\
-\end{array}$ & $\begin{array}{c}250 \\
8.2 \\
3\end{array}$ & $\begin{array}{l}- \\
-\end{array}$ \\
\hline $\begin{array}{l}\text { Nickel (Ni) } \\
\text { Selenium (Se) } \\
\text { Strontium (Sr) } \\
\text { Zinc (Zn) }\end{array}$ & $\bar{z}$ & $\begin{array}{r}\overline{-} \\
17,300 \\
20\end{array}$ & $\begin{array}{r}250 \\
10 \\
2,500 \\
60 \\
\end{array}$ & $\overline{\bar{E}}$ \\
\hline
\end{tabular}


TABLE 27. - Inorganic analyses of ground water from well 11, 855-1035 feet below

[Values in parentheses are from analysis by E. A. Jenne]

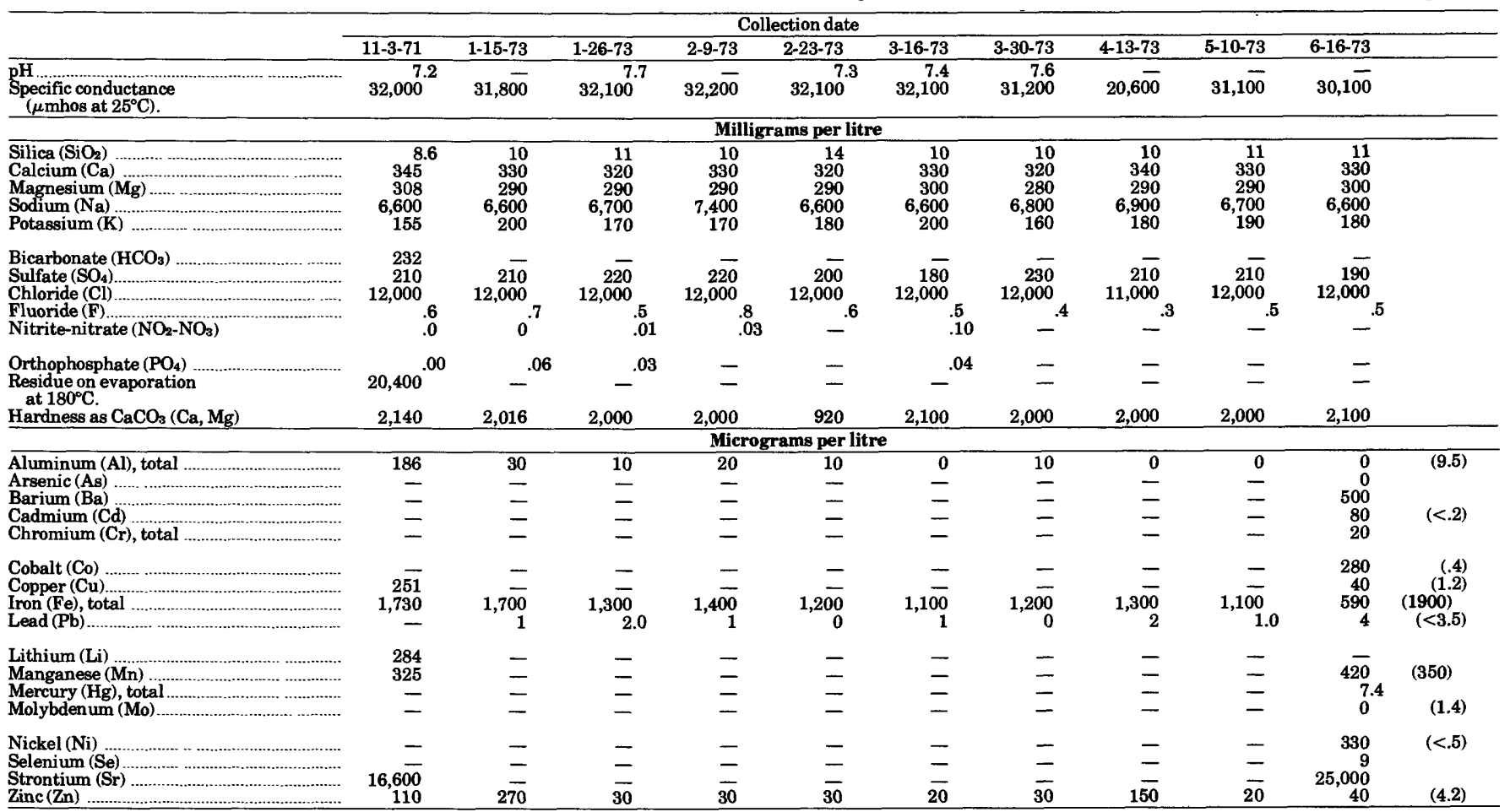

TABLE 29. - Inorganic analyses of ground water

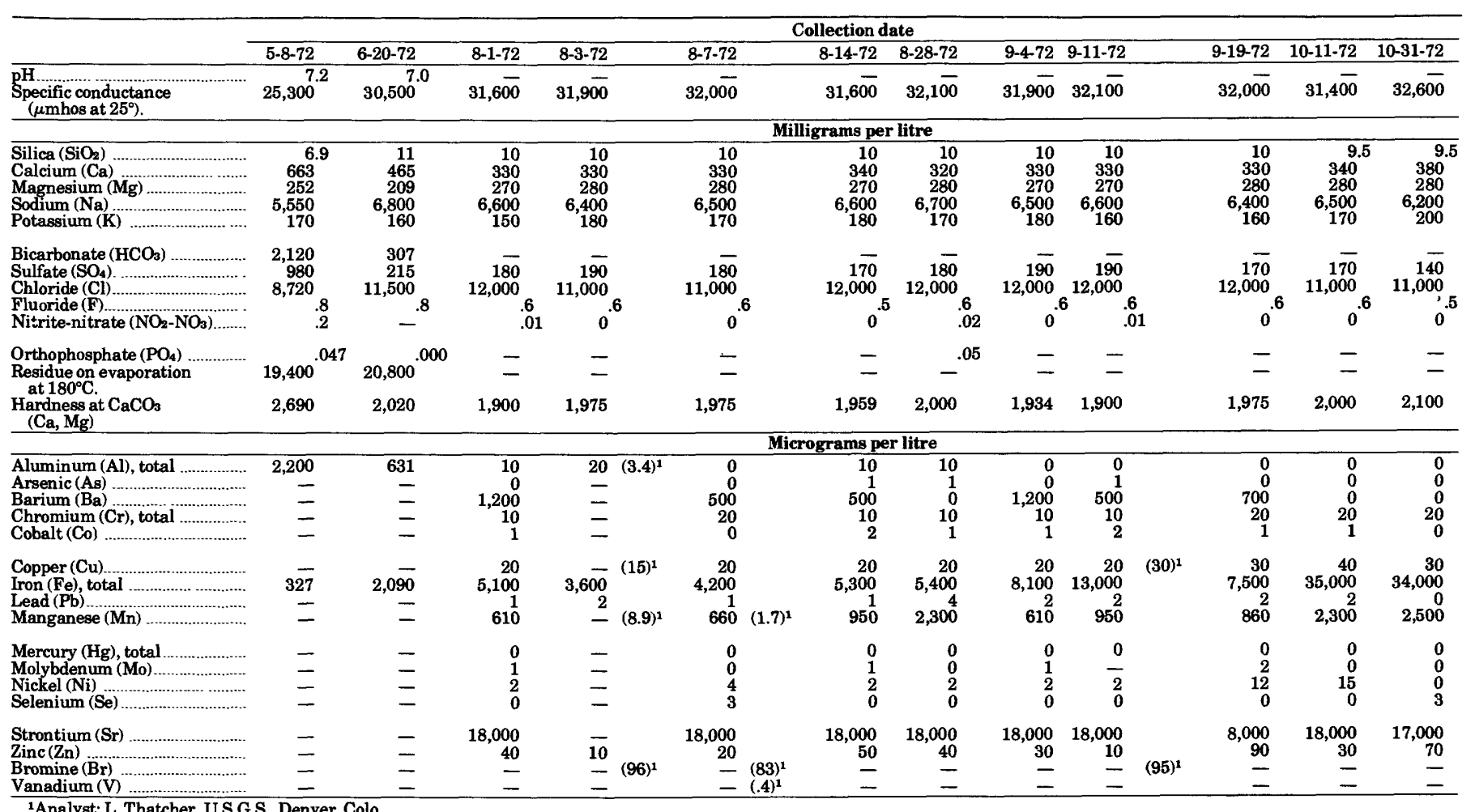

1Analyst: L. Thatcher, U.S.G.S., Denver, Colo
2Analyst: E. A. Jenne, U.S.G.S., Menlo Park, Calif. 
land surface

\begin{tabular}{|c|c|c|c|}
\hline $7-3-73$ & 7-20-73 & $9-14-73$ & $10-31-73$ \\
\hline $31,6 \overline{0}$ & $31,3 \overline{0}$ & $30,5 \overline{00}$ & $33,3 \overline{00}$ \\
\hline $\begin{array}{r}11 \\
320 \\
290 \\
6,300 \\
170\end{array}$ & $\begin{array}{r}11 \\
330 \\
290 \\
6,800 \\
170\end{array}$ & $\begin{array}{r}11 \\
320 \\
290 \\
7,000 \\
190\end{array}$ & $\begin{array}{r}11 \\
330 \\
300 \\
6,800 \\
210\end{array}$ \\
\hline $\begin{array}{r}2 \overline{00} \\
12,000 \\
\end{array}$ & $\begin{array}{r}2 \overline{10} \\
12,000 \\
{ }_{7}\end{array}$ & $\begin{array}{c}12,000 \\
12,4\end{array}$ & $\begin{array}{c}1 \overline{700} \\
14,000 \\
{ }_{3}\end{array}$ \\
\hline - & - & - & .9 \\
\hline 2,000 & 2,000 & 2,000 & 2,100 \\
\hline 0 & 20 & 10 & 10 \\
\hline$=$ & Z & $=$ & $=$ \\
\hline $\bar{z}$ & $\overline{-}$ & $\bar{z}$ & Z \\
\hline- & - & - & - \\
\hline $\begin{array}{r}4 \overline{80} \\
1\end{array}$ & $\begin{array}{r}5 \overline{10} \\
2\end{array}$ & $\begin{array}{r}35 \overline{0} \\
3\end{array}$ & $\begin{array}{r}290 \\
2\end{array}$ \\
\hline$=$ & $=$ & $=$ & $=$ \\
\hline $\bar{z}$ & $\bar{z}$ & $\bar{z}$ & $=$ \\
\hline$=$ & $\bar{z}$ & $\bar{z}$ & $=$ \\
\hline$\overline{20}$ & $\overline{90}$ & $\overline{60}$ & $\overline{40}$ \\
\hline
\end{tabular}

TABLE 28. - Inorganic analyses of ground water from well 12, 838974 feet below land surface [Values in parentheses are from analysis by $\mathrm{E}$. A. Jenne]

\begin{tabular}{|c|c|c|c|c|}
\hline & \multicolumn{4}{|c|}{ Collection date } \\
\hline \multirow{3}{*}{$\begin{array}{l}\text { pH } \\
\text { Specific conductance } \\
\left(\mu \text { mhos at } 25^{\circ} \mathrm{C}\right) .\end{array}$} & \multirow{2}{*}{\multicolumn{2}{|c|}{$\begin{array}{r}\text { Collect } \\
6-16-73 \\
31,400\end{array}$}} & \multirow{2}{*}{\multicolumn{2}{|c|}{\begin{tabular}{r|}
$10-31-73$ \\
32,100
\end{tabular}}} \\
\hline & & & & \\
\hline & \multicolumn{4}{|c|}{ Milligrams per litre } \\
\hline 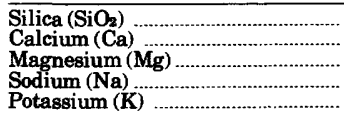 & $\begin{array}{c}9.0 \\
338 \\
310 \\
6,650 \\
150\end{array}$ & $\begin{array}{r}37.7 \\
300 \\
6,600 \\
190\end{array}$ & & $\begin{array}{r}\mathbf{3 . 6} \\
180 \\
300 \\
7,000 \\
210\end{array}$ \\
\hline $\begin{array}{l}\text { Bicarbonate }\left(\mathrm{HCO}_{3}\right) \\
\text { Sulfate }\left(\mathrm{SO}_{4}\right) \ldots \\
\text { Chloride (C) } \\
\text { Fluoride (F) } \\
\text { Nitrite-nitrate }\left(\mathrm{NO}_{3}-\mathrm{NO}_{3}\right) \\
\end{array}$ & $\begin{array}{r}233 \\
250 \\
11,900 \\
.6 \\
.0\end{array}$ & $\begin{array}{c}240 \\
12,000 \\
0.4\end{array}$ & & $\begin{array}{r}220 \\
12,000 \\
.2\end{array}$ \\
\hline $\begin{array}{l}\text { Orthophosphate }\left(\mathrm{PO}_{4}\right) \\
\text { Residue on evaporation at } \\
180^{\circ} \mathrm{C} \text {. }\end{array}$ & $20,600{ }^{.03}$ & $\bar{z}$ & & \\
\hline Hardness as $\mathrm{CaCO}_{3}(\mathrm{Ca}, \mathrm{Mg})$ & \multicolumn{4}{|c|}{ Micrograms per litre } \\
\hline 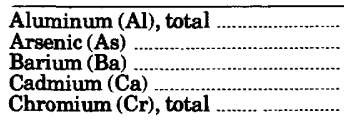 & $\begin{array}{l}445 \\
= \\
=\end{array}$ & $\begin{array}{r}0 \\
00 \\
500 \\
80 \\
20\end{array}$ & $(<1.0)$ & $\begin{array}{l}0 \\
\bar{z} \\
-\end{array}$ \\
\hline 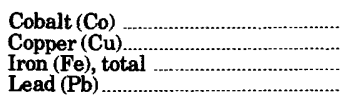 & $\begin{array}{r}2 \overline{66} \\
5,253\end{array}$ & $\begin{array}{r}250 \\
50 \\
31,100 \\
5\end{array}$ & $\begin{array}{r}(<.2) \\
(.9) \\
(31,000) \\
(<3.5)\end{array}$ & $\begin{array}{r}\overline{7} \\
07,000\end{array}$ \\
\hline $\begin{array}{l}\text { Lithium (Li) } \\
\text { Manganese (Mn) } \\
\text { Mercury (Hg), total } \\
\text { Molybdenum (Mo) }\end{array}$ & $\begin{array}{r}278 \\
265 \\
=\end{array}$ & $\begin{array}{r}6 \overline{10} \\
10 \\
0\end{array}$ & $(<1.2)$ & $\bar{z}$ \\
\hline 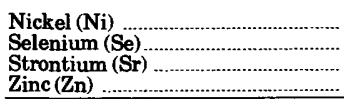 & $\begin{array}{r}\overline{-} \\
16,600 \\
49\end{array}$ & $\begin{array}{r}0 \\
0 \\
23,000 \\
30 \\
\end{array}$ & (2.8) & $\bar{z}$ \\
\hline
\end{tabular}

from well 14, 843-972 feet below land surface.

\begin{tabular}{|c|c|c|c|c|c|c|c|c|c|c|c|c|c|c|}
\hline \multicolumn{15}{|c|}{ Collection date } \\
\hline 11.7 .72 & 11-13-72 & $1-22-72$ & 11-30-72 & $12-5-72$ & $12-13-72$ & $2-19-72$ & 12-29-72 & $1-15-73$ & $1-26-73$ & $2-9-73$ & 2-23-73 & 6-16-73 & & $0-31-73$ \\
\hline 32,700 & $32,00 \overline{0}$ & 31,900 & $31,7 \overline{00}$ & $32,30 \overline{0}$ & $30,7 \overline{00}$ & $31,9 \overline{68}$ & $31,4 \overline{58}$ & $20,3 \overline{0}$ & $21,500.5$ & 31,000 & $31,400.3$ & 29,400 & & $31,39 \overline{5}$ \\
\hline \multicolumn{15}{|c|}{ Milligrams per litre } \\
\hline $\begin{array}{r}10 \\
330 \\
280 \\
6,400 \\
170\end{array}$ & $\begin{array}{r}10 \\
330 \\
280 \\
6,400 \\
170\end{array}$ & $\begin{array}{r}10 \\
3300 \\
2800 \\
6,900 \\
190\end{array}$ & $\begin{array}{r}10 \\
330 \\
280 \\
6,000 \\
170\end{array}$ & $\begin{array}{r}10 \\
310 \\
280 \\
6,800 \\
200\end{array}$ & $\begin{array}{r}10 \\
330 \\
270 \\
6,100 \\
180\end{array}$ & $\begin{array}{r}9.7 \\
330 \\
280 \\
6,900 \\
170\end{array}$ & $\begin{array}{c}9.0 \\
330 \\
280 \\
6,900 \\
170\end{array}$ & $\begin{array}{r}11 \\
310 \\
280 \\
6,800 \\
180\end{array}$ & $\begin{array}{r}11 \\
330 \\
290 \\
6,200 \\
160\end{array}$ & $\begin{array}{r}11 \\
320 \\
2700 \\
6,500 \\
170\end{array}$ & $\begin{array}{r}12 \\
320 \\
280 \\
6,500 \\
180\end{array}$ & $\begin{array}{r}11 \\
320 \\
280 \\
6,500 \\
180\end{array}$ & & $\begin{array}{r}9.9 \\
280 \\
280 \\
6,600 \\
200\end{array}$ \\
\hline $\begin{array}{r}12,000 \\
\quad .6 \\
\quad .02\end{array}$ & $\begin{array}{r}11,000 \\
\quad: 4 \\
0\end{array}$ & $\begin{array}{r}240 \\
12,000 \\
\quad .7\end{array}$ & $\begin{array}{r}240 \\
11,000 \\
\quad .6 \\
.03\end{array}$ & $\begin{array}{r}220 \\
12,000 \\
.7 \\
.03\end{array}$ & $\begin{array}{r}230 \\
12,000 \\
\quad{ }_{0} 8\end{array}$ & $\begin{array}{r}210 \\
12,000 \\
\quad .6 \\
.02\end{array}$ & $\begin{array}{r}2 \overline{250} \\
12,000 \\
\quad .6 \\
\quad .61\end{array}$ & $\begin{array}{r}190 \\
11,000 \\
{ }_{.02}\end{array}$ & $\begin{array}{r}180 \\
12,000 \\
.5 \\
.04\end{array}$ & $\begin{array}{r}210 \\
12,000 \\
\quad{ }_{.8}^{8}\end{array}$ & $\begin{array}{r}210 \\
11,000 \\
\quad .6\end{array}$ & $\begin{array}{r}190 \\
11,000 \\
\quad .5\end{array}$ & & $\begin{array}{r}230 \\
12,000 \\
\quad .4\end{array}$ \\
\hline$=$ & $=$ & $\bar{z} \cdot+\cdot+x+1$ & $=$ & $=$ & $\underline{0}$ & $=$ & 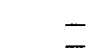 & .08 & 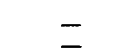 & $=$ & $=$ & $\bar{z}+x+r+1$ & & $\ldots .07$ \\
\hline 42,000 & 1,975 & 2,000 & 2,000 & 1,900 & 1,934 & 2,000 & 2,000 & 1,900 & 2,000 & 1,900 & 910 & 2,000 & & 2,000 \\
\hline \multicolumn{15}{|c|}{ Micrograms per litre } \\
\hline $\begin{array}{c}10 \\
0\end{array}$ & $\underline{0}$ & 10 & 20 & 0 & $\underline{0}$ & $\begin{array}{l}0 \\
0\end{array}$ & $\begin{array}{l}0 \\
0\end{array}$ & 10 & 10 & 0 & 0 & 10 & $(2.5)^{2}$ & $\underline{10}$ \\
\hline $\begin{array}{r}1,000 \\
20 \\
1\end{array}$ & $\bar{z}$ & $\bar{z}$ & $\bar{z}$ & $\begin{array}{r}700 \\
10 \\
0\end{array}$ & $\bar{z}$ & $\underline{z}$ & $=$ & $=$ & $\begin{array}{r}300 \\
10 \\
0\end{array}$ & 三 & $\begin{array}{r}400 \\
10 \\
0\end{array}$ & $\bar{z}$ & $(<.2)^{2}$ & $\bar{z}$ \\
\hline $\begin{array}{r}18,000 \\
1 \\
650\end{array}$ & $\begin{array}{r}11,000 \\
0\end{array}$ & $\begin{array}{r}8,300 \\
0\end{array}$ & $\begin{array}{r}3,9 \overline{0} \\
\underline{0}\end{array}$ & $\begin{array}{r}30 \\
3,400 \\
0 \\
280\end{array}$ & $\begin{array}{r}4,2 \overline{0} \\
\underline{0}\end{array}$ & $\begin{array}{r}1,400 \\
2\end{array}$ & $\begin{array}{r}3,600 \\
2 \\
\end{array}$ & $\begin{array}{r}1,300 \\
1 \\
\end{array}$ & $\begin{array}{r}30 \\
880 \\
0 \\
300\end{array}$ & $\begin{array}{r}9 \overline{0} \\
3 \\
\end{array}$ & $\begin{array}{r}30 \\
1,200 \\
250 \\
250\end{array}$ & $\underset{3}{2,8 \overline{0}}$ & $\begin{array}{r}(.6)^{2} \\
(.2)^{2} \\
(6,500)^{2} \\
(1.0)^{2}\end{array}$ & $\begin{array}{r}\overline{5} \\
5,400 \\
0\end{array}$ \\
\hline 0 & - & - & - & 0 & - & - & - & - & 0 & - & 0 & - & $(620)^{2}$ & - \\
\hline $\begin{array}{l}5 \\
0\end{array}$ & $\bar{z}$ & $\bar{z}$ & $\bar{z}$ & $\begin{array}{l}1 \\
0 \\
4\end{array}$ & 三 & $\bar{z}$ & $\bar{z}$ & $\bar{z}$ & $\begin{array}{l}1 \\
0 \\
0\end{array}$ & $\bar{z}$ & $\begin{array}{l}1 \\
\frac{1}{4}\end{array}$ & $\bar{z}$ & $(<1.2)^{2}$ & $\bar{z}$ \\
\hline $\begin{array}{r}18,000 \\
60\end{array}$ & $\overline{30}$ & $\overline{40}$ & 100 & $\begin{array}{r}1,900 \\
90\end{array}$ & $\overline{20}$ & $\overline{70}$ & $\overline{20}$ & $\overline{30}$ & 18,600 & $\overline{30}$ & $\begin{array}{r}19,000 \\
40\end{array}$ & $=$ & & 二 \\
\hline 二 & $=$ & $=$ & $=$ & $=$ & $=$ & $=$ & $=$ & $=$ & $=$ & $=$ & $=$ & 60 & $(5.7)^{2}$ & 80 \\
\hline
\end{tabular}



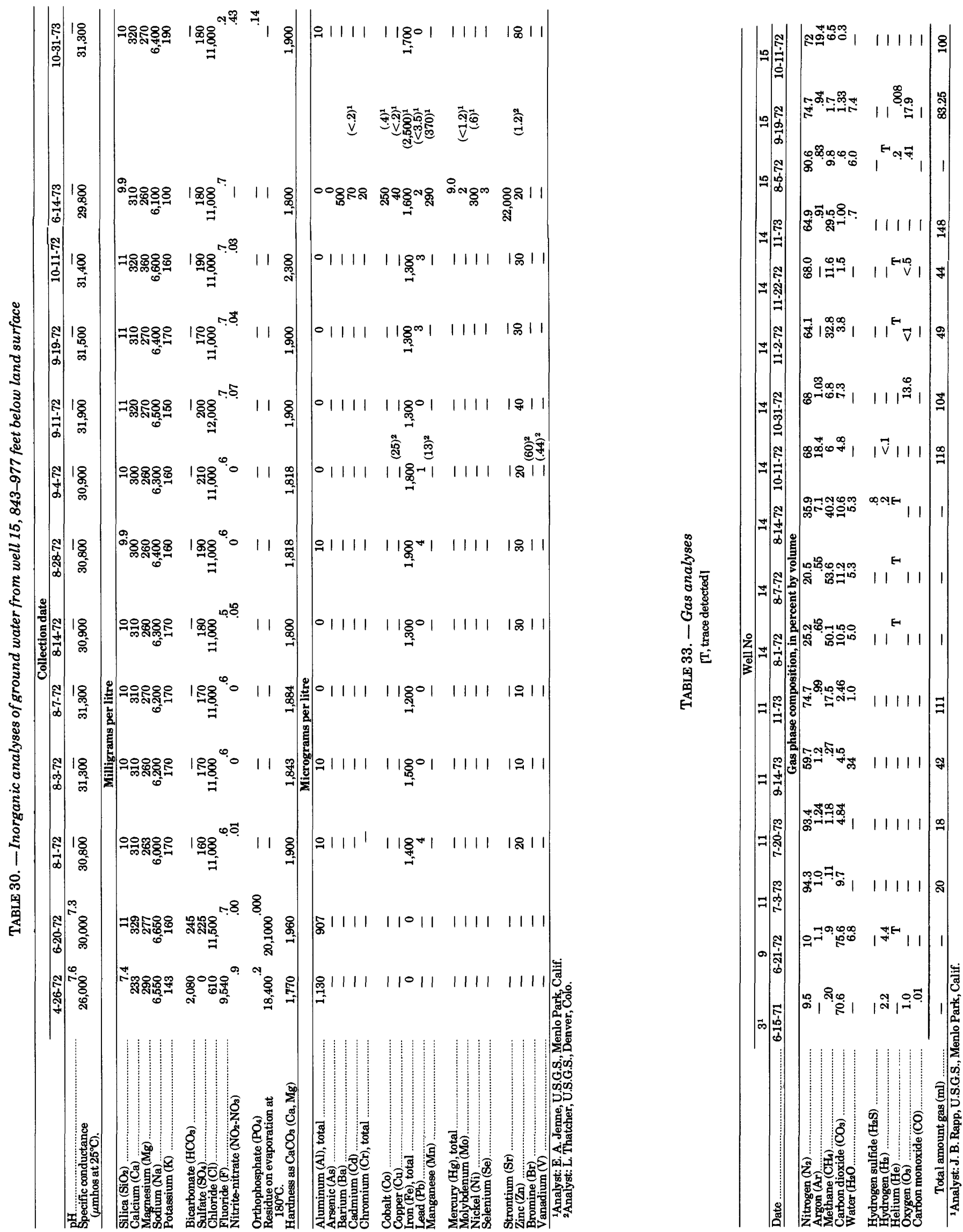
TABLE 31.-Inorganic analyses of ground water from well 16, 843-983 feet below land surface

[Values in parentheses are from analysis by E. A. Jenne]

\begin{tabular}{|c|c|c|c|c|c|}
\hline \multirow{3}{*}{$\begin{array}{l}\mathrm{pH} \\
\text { Specific conductance } \\
\left(\mu \mathrm{mh} o \mathrm{~s} \text { at } 25^{\circ} \mathrm{C}\right)\end{array}$} & \multicolumn{5}{|c|}{ Collection date } \\
\hline & $\begin{array}{l}5-18-72 \\
7.7 \\
31,000\end{array}$ & $\begin{array}{c}6-20-72 \\
7.2 \\
31,800\end{array}$ & $\begin{array}{r}6-14-73 \\
31,600\end{array}$ & \multicolumn{2}{|r|}{$\begin{array}{r}10-31-73 \\
32,118\end{array}$} \\
\hline & \multicolumn{5}{|c|}{ Milligrams per litre } \\
\hline $\begin{array}{l}\text { Silica }\left(\mathrm{SiO}_{2}\right) \\
\text { Calcium }(\mathrm{Ca}) \\
\text { Magnesium }(\mathrm{Mg}) \\
\text { Sodium }(\mathrm{Na}) \\
\text { Potassium (K) }\end{array}$ & $\begin{array}{r}9.8 \\
330 \\
323 \\
7,350 \\
175\end{array}$ & $\begin{array}{r}10 \\
369 \\
311 \\
6,750 \\
175\end{array}$ & $\begin{array}{c}9.7 \\
340 \\
300 \\
6,600 \\
190\end{array}$ & & $\begin{array}{l}9.8 \\
350 \\
310 \\
7,000 \\
220\end{array}$ \\
\hline $\begin{array}{l}\text { Bicarbonate }\left(\mathrm{HCO}_{3}\right) \\
\text { Sulfate }\left(\mathrm{SO}_{4}\right) \\
\text { Chloride }(\mathrm{Cl}) \\
\text { Fluoride }(\mathrm{F}) \\
\text { Nitrite-nitrate }\left(\mathrm{NO}_{2}-\mathrm{NO}_{3}\right)\end{array}$ & $\begin{array}{r}228 \\
615 \\
12,200 \\
.6 \\
.07\end{array}$ & $\begin{array}{r}220 \\
255 \\
12,200 \\
.6 \\
.00\end{array}$ & $\begin{array}{r}240 \\
12,000 \\
-\end{array}$ & & $\begin{array}{r}28 \overline{130} \\
13,000 \\
.3 \\
.01\end{array}$ \\
\hline $\begin{array}{l}\text { Orthophosphate }\left(\mathrm{PO}_{4}\right) \text {...... } \\
\text { Residue on evaporation } \\
\text { at } 180^{\circ} \mathrm{C} \text {. }\end{array}$ & $21,300^{.000}$ & $21,000^{.000}$ & - & & $-^{.11}$ \\
\hline $\begin{array}{l}\mathrm{Hardness} \text { as } \mathrm{CaCO}_{3} \\
(\mathrm{Ca}, \mathrm{Mg})\end{array}$ & 2,150 & 2,200 & 2,100 & & 2,200 \\
\hline & \multicolumn{5}{|c|}{ Micrograms per litre } \\
\hline $\begin{array}{l}\text { Aluminum (Al) } \\
\text { Arsenic (As) } \\
\text { Barium (Ba) } \\
\text { Cadmium (Cd) } \\
\text { Chromium (Cr), total }\end{array}$ & $\begin{array}{r}1,000 \\
= \\
=\end{array}$ & $\begin{array}{r}1,120 \\
= \\
=\end{array}$ & $\begin{array}{r}10 \\
3 \\
300 \\
70 \\
10\end{array}$ & $(<.1)$ & $\begin{array}{l}0 \\
\overline{-} \\
-\end{array}$ \\
\hline $\begin{array}{l}\text { Cobalt (Co) } \\
\text { Copper (Cu) } \\
\text { Iron (Fe), total } \\
\text { Lead (Pb) } \\
\text { Manganese (Mn) }\end{array}$ & $\begin{array}{l}\overline{-} \\
\overline{0} \\
-\end{array}$ & $\begin{array}{l}\overline{-} \\
\underline{-}\end{array}$ & $\begin{array}{r}280 \\
30 \\
2,400 \\
2 \\
480\end{array}$ & $\begin{array}{r}(.6) \\
(14) \\
(5800) \\
(<3.5) \\
(390)\end{array}$ & $\begin{array}{r}\overline{-} \\
2,600 \\
0 \\
-\end{array}$ \\
\hline $\begin{array}{l}\text { Mercury (Hg), total } \\
\text { Molybdenum (Mo) } \\
\text { Nickel (Ni) } \\
\text { Selenium (Se) } \\
\text { Strontium (Sr) } \\
\text { Zinc (Zn) }\end{array}$ & $\begin{array}{l}\bar{z} \\
\bar{z}\end{array}$ & $\begin{array}{l}= \\
= \\
=\end{array}$ & $\begin{array}{r}13 \\
4 \\
300 \\
11 \\
24,000 \\
0\end{array}$ & $\begin{aligned}(<1.2) \\
(<.5)\end{aligned}$ & $\begin{array}{l}\bar{z} \\
\bar{z} \\
\overline{40}\end{array}$ \\
\hline
\end{tabular}

TABLE 32.-Inorganic analyses of ground water from wells 2, 3, 4, and 5

\begin{tabular}{|c|c|c|c|c|}
\hline & \multicolumn{4}{|c|}{ Well No. } \\
\hline & 2 & 3 & 4 & 5 \\
\hline $\begin{array}{l}\text { Zone (feet below land surface) } \\
\text { Collection date } \\
\text { pH } \\
\text { Specific conductance } \\
\left(\mu \text { mhos at } 25^{\circ} \mathrm{C}\right)\end{array}$ & $\begin{array}{c}855-1025 \\
6-15-71 \\
3.9 \\
6,560\end{array}$ & $\begin{array}{c}660-690 \\
6-15-71 \\
4.3 \\
11,000\end{array}$ & $\begin{array}{c}854-1025 \\
6-16-71 \\
4.0 \\
8,280\end{array}$ & $\begin{array}{r}854-1025 \\
6-15-71 \\
4.0 \\
8,080\end{array}$ \\
\hline & \multicolumn{4}{|c|}{ Milligrams per litre } \\
\hline $\begin{array}{l}\text { Silica }\left(\mathrm{SiO}_{2}\right) \\
\mathrm{Calcium}(\mathrm{Ca}) \\
\text { Magnesium }(\mathrm{Mg}) \\
\text { Sodium }(\mathrm{Na}) \\
\text { Potassium }(\mathrm{K})\end{array}$ & $\begin{array}{r}41 \\
1,760 \\
24 \\
12 \\
4.1\end{array}$ & $\begin{array}{r}34 \\
3,186 \\
85 \\
198 \\
56\end{array}$ & $\begin{array}{r}23 \\
2,525 \\
34 \\
2.9 \\
2.2\end{array}$ & $\begin{array}{c}34 \\
2,364 \\
49 \\
3.2 \\
2.3\end{array}$ \\
\hline $\begin{array}{l}\text { Bicarbonate }\left(\mathrm{HCO}_{3}\right) \\
\text { Sulfate }\left(\mathrm{SO}_{4}\right) \\
\text { Chloride }(\mathrm{Cl}) \\
\text { Fluoride }(\mathrm{F}) \\
\text { Nitrite-nitrate }\left(\mathrm{NO}_{2}-\mathrm{NO}_{2}\right)\end{array}$ & $\begin{array}{c}0 \\
9.6 \\
64 \\
64 \\
3.2 \\
3.9\end{array}$ & $\begin{array}{l}0 \\
35 \\
1.1 \\
5.6\end{array}$ & $\begin{array}{r}\overline{8.0} \\
230 \\
1.3 \\
\mathbf{3 . 9}\end{array}$ & $\begin{array}{r}\overline{19} \\
144 \\
1.3 \\
3.9\end{array}$ \\
\hline $\begin{array}{l}\text { Orthophosphate }\left(\mathrm{PO}_{4}\right) \\
\text { Residue on evaporation at } \\
180^{\circ} \mathrm{C} \text {. }\end{array}$ & $6,800^{1.5}$ & $1,330^{4.2}$ & $9,590^{1.3}$ & $9,160^{1.1}$ \\
\hline Hardness as $\mathrm{CaCO}_{3}(\mathrm{Ca}, \mathrm{Mg})$ & \multicolumn{4}{|c|}{ Micrograms per litre } \\
\hline $\begin{array}{l}\text { Aluminum }(\mathrm{Al}) \text {, total } \\
\text { Copper }(\mathrm{Cu}) \\
\text { Iron }(\mathrm{Fe}) \text {, total } \\
\text { Manganese }(\mathrm{Mn}) \\
\text { Zinc }(\mathrm{Zn})\end{array}$ & $\begin{array}{r}6,900 \\
50 \\
8,780 \\
450 \\
167 \\
\end{array}$ & $\begin{array}{r}3,250 \\
900 \\
31,000 \\
3,600 \\
5,900 \\
\end{array}$ & $\begin{array}{r}6,800 \\
167 \\
8,280 \\
280 \\
136 \\
\end{array}$ & $\begin{array}{r}7,100 \\
110 \\
8,000 \\
285 \\
125 \\
\end{array}$ \\
\hline
\end{tabular}

TABLE 34. - Organic analyses of ground water from well 11

[ND, not detected]

\begin{tabular}{|c|c|c|c|c|c|c|c|c|c|c|c|}
\hline & \multicolumn{11}{|c|}{ Date } \\
\hline & $1-15-73$ & $1-26-73$ & $2-9-73$ & $2-23-73$ & 3-16-73 & $3-30-73$ & 4-13-73 & $5-10-73$ & 6-16-73 & $7-3-73$ & $7-20-73$ \\
\hline & \multicolumn{11}{|c|}{ Milligrams per litre } \\
\hline 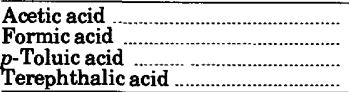 & $\begin{array}{r}13.85 \\
\mathrm{ND} \\
\mathrm{ND} \\
.283\end{array}$ & $\begin{array}{l}4.37 \\
\mathrm{ND} \\
\mathrm{ND} \\
.301\end{array}$ & $\begin{array}{l}9.65 \\
\text { ND } \\
\text { ND } \\
.306\end{array}$ & $\begin{array}{r}18.52 \\
\text { ND } \\
\text { ND } \\
.19\end{array}$ & $\begin{array}{r}20.97 \\
\text { ND } \\
\text { ND } \\
.269\end{array}$ & $\begin{array}{r}22.45 \\
\text { ND } \\
\text { ND } \\
.49\end{array}$ & $\begin{array}{r}24.07 \\
\text { ND } \\
\text { ND } \\
.422\end{array}$ & $\begin{array}{r}26.32 \\
\text { ND } \\
\text { ND } \\
.538\end{array}$ & $\begin{array}{l}29.42 \\
\text { ND } \\
\text { ND } \\
.578\end{array}$ & $\begin{array}{r}41.52 \\
\text { ND } \\
\text { ND } \\
.488\end{array}$ & $\begin{array}{r}24.24 \\
\text { ND } \\
\text { ND } \\
.573 \\
\end{array}$ \\
\hline
\end{tabular}

TABLE 35.-Organic analyses of ground water from well 14

[ND, not detected]

\begin{tabular}{|c|c|c|c|c|c|c|c|c|c|c|}
\hline & \multicolumn{10}{|c|}{ Date } \\
\hline & $8-1-72$ & $8-7-72$ & 8-14-72 & $8-28-72$ & $9-4-72$ & $9-11-72$ & $9-19-72$ & $10-11-72$ & $10-31-72$ & 11-2-72 \\
\hline & \multicolumn{10}{|c|}{ Milligrams per litre } \\
\hline $\begin{array}{l}\text { Acetic acid } \\
\text { Formic acid } \\
\text { p-Toluic acid } \\
\text { Terephthalic acid }\end{array}$ & $\begin{array}{r}19.67 \\
\text { ND } \\
.462 \\
.227 \\
\end{array}$ & $\begin{array}{c}55.38 \\
\mathrm{ND} \\
1.78 \\
.856 \\
\end{array}$ & $\begin{array}{r}71.98 \\
\mathrm{ND} \\
1.528 \\
.754 \\
\end{array}$ & $\begin{array}{r}101.35 \\
.16 \\
1.688 \\
.930 \\
\end{array}$ & $\begin{array}{r}85.94 \\
.60 \\
1.508 \\
.790 \\
\end{array}$ & $\begin{array}{r}138.6 \\
1.42 \\
1.449 \\
.332 \\
\end{array}$ & $\begin{array}{c}59.61 \\
1.38 \\
.949 \\
.182 \\
\end{array}$ & $\begin{array}{c}474.70 \\
1.10 \\
6.648 \\
3.327 \\
\end{array}$ & $\begin{array}{r}758.85 \\
1.27 \\
16.69 \\
7.45 \\
\end{array}$ & $\begin{array}{l}60.23 \\
\text { ND } \\
.856 \\
.398 \\
\end{array}$ \\
\hline & \multicolumn{10}{|c|}{ Date } \\
\hline & 11-7-72 & $11-13-72$ & 11-22-72 & $11-30-72$ & $12-5-72$ & 12-13-72 & $12-19-72$ & $12-29-72$ & $1-15-73$ & $2-9-73$ \\
\hline & \multicolumn{10}{|c|}{ Milligrams per litre } \\
\hline $\begin{array}{l}\text { Acetic acid } \\
\text { Formic acid } \\
\text { p-Toluic acid } \\
\text { Terephthalic acid }\end{array}$ & $\begin{array}{c}63.81 \\
3.08 \\
1.258 \\
.617 \\
\end{array}$ & $\begin{array}{r}84.07 \\
.657 \\
1.386 \\
.723\end{array}$ & $\begin{array}{l}20.00 \\
\mathrm{ND} \\
.468 \\
.200\end{array}$ & $\begin{array}{l}4.90 \\
\mathrm{ND} \\
.131 \\
.062\end{array}$ & $\begin{array}{c}11.66 \\
.95 \\
.301 \\
.187\end{array}$ & $\begin{array}{r}21.07 \\
\mathrm{ND} \\
.493 \\
.157 \\
\end{array}$ & $\begin{array}{l}- \\
-.161 \\
.051\end{array}$ & $\begin{array}{l}.71 \\
\mathrm{ND} \\
.151 \\
.042 \\
\end{array}$ & $\begin{array}{l}\overline{-}_{.1} \\
.044\end{array}$ & $\begin{aligned} & \text { ND } \\
& \text { ND } \\
&- \\
&- \\
&\end{aligned}$ \\
\hline
\end{tabular}

TABLE 36.-Organic analyses of ground water from well 15 [ND, not detected]

\begin{tabular}{|c|c|c|c|c|c|}
\hline & \multicolumn{5}{|c|}{ Date } \\
\hline & $8-3-72$ & $8-7-72$ & $8-14-72$ & $10-31-72$ & $12-5-72$ \\
\hline & \multicolumn{5}{|c|}{ Milligrams per litre } \\
\hline 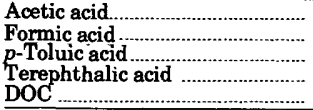 & $\begin{array}{l}9.20 \\
\text { ND } \\
.25 \\
.15 \\
5.5\end{array}$ & $\begin{array}{l}4.13 \\
\mathrm{ND} \\
.242 \\
.064 \\
5.0\end{array}$ & $\begin{array}{l}5.09 \\
\text { ND } \\
.245 \\
.059 \\
5.5\end{array}$ & $\begin{array}{l}\text { ND } \\
\text { ND } \\
\text { ND } \\
\text { ND } \\
3.0\end{array}$ & $\begin{array}{l}\text { ND } \\
\text { ND } \\
\text { ND } \\
\text { ND } \\
1.5\end{array}$ \\
\hline
\end{tabular}

